\title{
Processions, Propaganda, and Pixels: Reconstructing the Sacred Way Between Miletos and Didyma
}

ANJA SLAWISCH AND TOBY CHRISTOPHER WILKINSON

\author{
Open Access on AJA Online \\ Includes Supplementary Content on AJA Online
}

American Journal of Archaeology Volume 122, Number 1

January 2018

Pages 101-43

DOI: $10.3764 /$ aja.122.1.0101

www.ajaonline.org

\footnotetext{
${ }^{1}$ We would like to thank Stephen Mitchell, Ludwig Meier, Ulf Weber, and Jan-Henrik Hartung for comments and advice; to Christof Berns and Sabine Huy for access to material from the Miletarchiv at the Ruhr-Universität Bochum; to Gregor Borg for organizing access to Katrin Kärner's unpublished thesis on the geology around Mavişehir; and to Dominique Krüger for scanning some of the diagrams. We are very grateful to Helga Bumke for permission to reuse plans and photographs from the Didymaarchiv at the Deutsches Archäologisches Institut (DAI) in Berlin. Thanks also to Michael Loy, Néhémie Strupler, and Çagatay Çelik for rewalking Wilski's Antike Strasse with us. The excavations and survey at Panormos were financially supported by the DAI and undertaken with the collaboration of the Milet Museum; thanks especially to Hasibe Akat for permission to examine the museum archives. Figures are our own unless otherwise noted. We are also grateful to the editorial team at the $A J A$ and to the three anonymous reviewers for their valuable suggestions for improvement to the manuscript. This article was completed as part of a project that has received funding from the European Union's Horizon 2020 research and innovation program under grant agreement no. 700769. Translations are our own unless otherwise noted. Two appendices can be found under this article's abstract on AJA Online (www.ajaonline.org).
} 
topic of interest to researchers of, locals from, and visitors to the region. Recent local government initiatives to boost activity-based tourism, presumably to augment the current beach-oriented focus of the popular Turkish resort of Didim, have even included the establishment of a Sacred Way hiking path between Balat (Miletos) and the temple at Didim (Didyma) in an obvious attempt to emulate other successful hiking routes with historical flavor in Turkey, such as the Lycian Way. ${ }^{2}$ As is outlined in more detail below, academic interest in the Sacred Way has grown over the approximately 200 years of antiquarian exploration and archaeological research in the region. Much of this work has focused on epigraphic and architectural finds from excavations at Didyma and Miletos. Sporadic attention has been paid to monuments and finds identified across a wider swath of the peninsula in order to draw a map of connection between them. The road represents a leitmotif for the political, economic, and religious symbiosis (or otherwise) of these two important locales.

Two complementary projects - the establishment of a hiking path and the academic discourse that informs it - are in danger of constructing and maintaining an ossified and potentially anachronistic narrative of the Sacred Way. Each aims to fix and assert authority over the location and character of the Sacred Way to create a single authentic or authorized version of the route. This authorized route can thereby be projected backward in time to the Archaic era and assumed to remain essentially static. In fact, much of the history, function, and location of the Milesian Sacred Way remain elusive. This is despite the fact that it is considered one of the best textually documented of such "sacred ways" from classical antiquity. ${ }^{3}$ As a basis for understanding these other cases, the Milesian example therefore deserves to be more than a footnote in the local history of the peninsula. It is consequently vital that orthodox perspectives on the evidence be periodically interrogated and reassessed to avoid the creation of false security in our interpretations of the past. As we later argue, the modern projects of assert-

\footnotetext{
${ }^{2}$ Clow 2014.

${ }^{3}$ References to sacred ways in the Greek world are very few before the second century B.C.E. The only earlier example is Hdt. 6.34.2. A list of later sources mentioning sacred ways at Eleusis, Delphi, Olympia, Didyma, Labraunda, and Rome is provided in Bekker-Nielsen 2009, 9 nn. 3-8.
}

ing authority over the road may, however, have antique precedents.

General academic discussion of historical routes is often trapped by the oft-assumed but rarely demonstrated principle of route inertia (i.e., that roads and routes follow the same course over very long periods of time). This is assumed to allow us to retroject later, better-documented routes onto older periods. ${ }^{4}$ In the case of the Milesian Sacred Way, on the basis of a reexamination of the epigraphic, archaeological, and topographic data, we argue that there are strong grounds for supposing at least some route dynamism. Changes in economic prosperity, fluctuating investment in religious or political activity, and natural transformations of the landscape may have all contributed to partial rerouting of the path(s) between Miletos and Didyma across the Akron Hills and almost certainly affected the degree of physical infrastructure installed along the path(s). Dramatic transformations in the geography of the peninsula, particularly the infilling of the Meander Valley through sedimentation, ${ }^{5}$ has meant that the outline and character of the region has changed substantially across the last 3,000 years. But these and other less obvious environmental changes are rarely incorporated into our historical discussions.

The historicity or otherwise of the procession(s) presumed to have followed the Sacred Way is not the main focus of our arguments here, even if it is necessary to touch on this topic. ${ }^{6}$ Nonetheless, it is possible to document the historical emergence and transformation of the concept of a sacred way in addition to applying this term to certain physical paths or routes. This helps us decouple the term from the physical roads or routes when appropriate. ${ }^{7}$ Ultimately, by resisting a monolithic characterization of the Milesian Sacred Way, we hope to encourage a debate on the status of this and other, similar roads as dynamic entities whose physical and ideational characters developed through time.

\footnotetext{
${ }^{4}$ On the concept of route inertia, see Wilkinson 2014, 65-94. ${ }^{5}$ Brückner et al. 2017 (with references).

${ }^{6}$ One of the many pitfalls here is the synonymous use of the terms "sacred way" and "processional way": a sacred way could have been used for processions but processions do not make a road sacred; cf. Bekker-Nielsen 2009, 11-12.

${ }^{7}$ Herda (2006), following similar suspicions about the use of the term "sacred way" in the Archaic period, prefers to call the (hypothetical) Sacred Way of the Archaic or Classical era a Prozessionsweg (i.e., processional way).
} 


\section{A HISTORY OF RESEARCH: THE DISCOVERY OF}

\section{THE SACRED WAY}

In 1812, the British head of the second expedition of the Society of Dilettanti, William Gell, noted succinctly in his diary: "SACRED WAY BRANCHIDAE went to the Port N. of Temple." ${ }^{8}$ This is the first modern reference to a sacred way in the region and sets the stage for contemporary academic interest in the topic. In the Antiquities of Ionia in 1821, Gell elaborated on his observations of the area near the newly reidentified Temple of Apollo at Didyma: "Nearly mid-way between the temple and the port commences the sacred way, lying in a hollow between two gentle banks, along which are placed, at certain intervals, sepulchres and statues of ancient workmanship." Gell's application of the term "sacred way" to a hollow way between the temple and its presumed port seems to have been made simply on the basis of the alignment of monuments. ${ }^{10}$ Indeed, his interpretation of the topography as a road was not universally accepted. ${ }^{11}$ Importantly, he did not associate the road with Miletos. Ludwig Ross, who published his 1844 observations of Didyma in 1850 as Die Statuen am heiligen Wege der Branchiden, also did not connect the road with Miletos. His use of the term "heiliger Weg" (sacred way) was likewise derived from the presence of the statues that have subsequently become known, problematically, as the "Branchidae" (and which will be discussed further below), drawing on parallel "sacred ways" from Egypt. ${ }^{12}$

This changed in 1873, when a French expeditionary team led by Olivier Rayet found an inscription during the excavations of the building complex in Miletos that subsequently came to be known as the Younger Sacred

\footnotetext{
${ }^{8}$ This entry from volume 3 of Gell's diary is reproduced in Tuchelt 1970, 18-19. Gell's notebook is archived at the Department of Greek and Roman Antiquities at the British Museum.

${ }^{9}$ Society of Dilettanti 1821, 47.

${ }^{10}$ There seems to have been wider interest in ancient Greek "sacred ways" by antiquarians and travelers of the time. Besides Gell's own discussions of sacred ways around Athens in his popular book (Gell 1819, 21, 24, 30, 32, 97, 101), Chandler had already discussed the route from Athens to Eleusia (Chandler 1776, 183-87), presumably on the basis of references from Paus. 1.36.3-7.

${ }^{11}$ French explorer and antiquarian Charles Texier, who visited Didyma in 1835 and who also commented on the topography of the area, suggested that the statues Gell observed had instead adorned the western side of a stadium rather than a road (Texier 1849, 325, 327, pl. 140, fig. 3; Tuchelt 1970, 25).

${ }^{12}$ Ross 1861; Tuchelt 1970, 25 n. 21.
}

Gate (fig. 1). This long Latin text, first published in $1900,{ }^{13}$ recorded significant building works on the road to the Temple of Apollo at Didyma (alternately the Sanctuary of Apollo, or simply the Didymaion) by the Roman emperor Trajan. Parallel inscriptions with very similar content in Latin and Greek, with the Greek versions referring to the road as "ódò (i.e., the Sacred Way), were later found in Didyma ca. 1909 , along with an apparently contemporary but ex situ milestone also mentioning the Sacred Way (again in Greek) and a length of 11,000 passus (equating to ca. $16.28 \mathrm{~km}) \cdot{ }^{14}$ A detailed discussion of these inscriptions is given below.

These finds firmly established the identity of the Sacred Way as a road connecting Miletos and Didyma. It might have been expected to reinforce Gell's interpretation of the row of seated figures at Didyma, but this does not seem to have happened instantly. When German excavators started their work at Miletos under Theodor Wiegand in 1899, one of the first activities was a detailed topographic survey of the entire Milesian Peninsula, undertaken by Paul Wilski (a part of which is shown in fig. 2), which included archaeological observations as well as the then-current place-names. ${ }^{15}$ Wilski recorded a road passing through the Stefania Hills (ancient Akron) that separate the peninsula into a northern and a southern zone. He labeled the road (in red, indicating ancient remains, on the original color map) simply "Antike Strasse." While this street has subsequently come to be equated with the Sacred Way, the association does not seem to have been made at the time, and Wilski did not mark the track at Didyma described by Gell as a sacred way. In a report of work published in 1901, Wiegand discusses the Sacred Way from Miletos to Didyma as having followed the coast from the modern village of Akköy to Didim (or Yeronda, as it was known in 1901), a route that lies to the west of the Stefania/Akron Hills and is

\footnotetext{
${ }^{13}$ For full transcription and history of publication, see Ehrhardt and Weiß 2011, 225.

${ }^{14}$ Ehrhardt and Weiß 2011, 234-36. Cf. the compilation in Tuchelt 1970, 25-8.

${ }^{15}$ Wilski 1906 . Note that though many of these place-names are no longer used locally, following the 1923 exchange of populations and subsequent 20th-century place-name reforms; archaeological reports often refer to them because Wilski's map was the most easily accessible and annotated document available for describing the peninsula.
} 


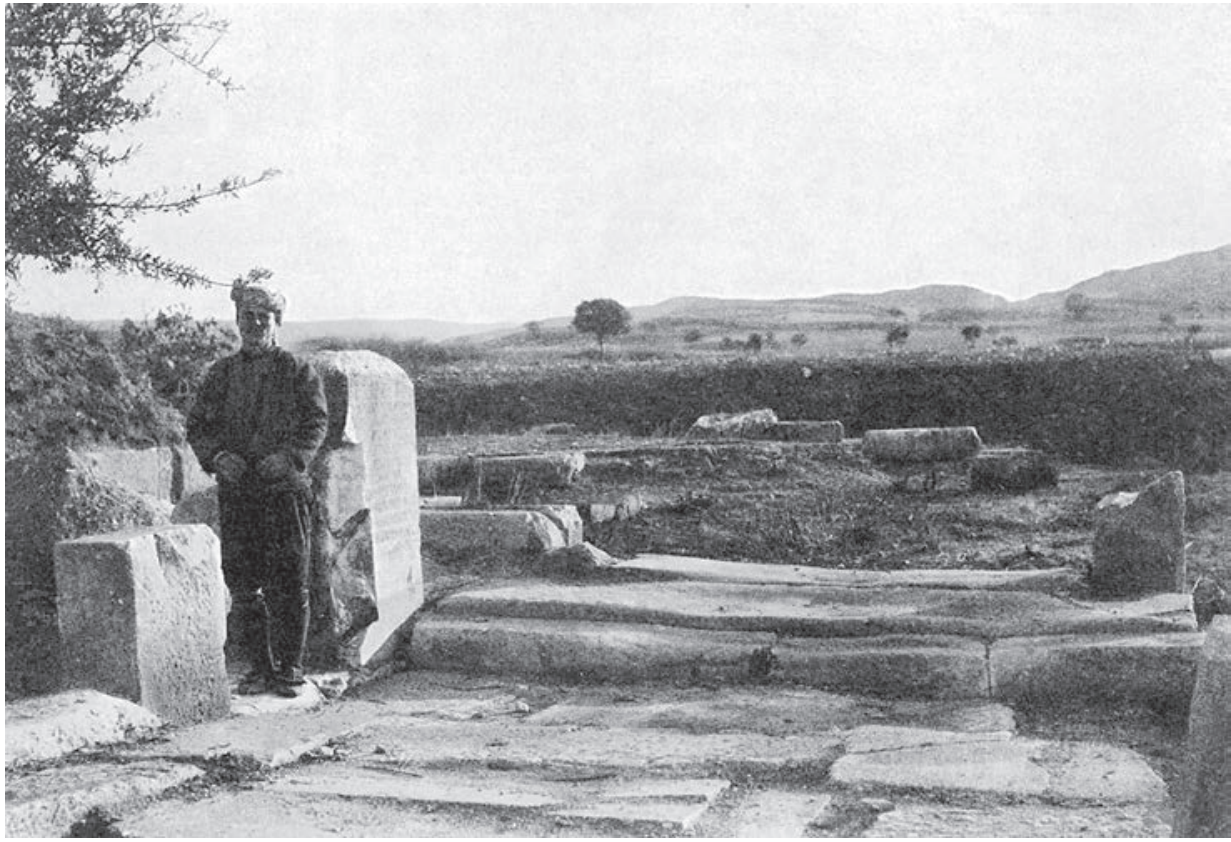

FIG. 1. The Younger Sacred Gate at Miletos, with the bilingual Trajanic inscription in situ, on the left side of the gate threshold looking south from inside (von Gerkan 1935, fig. 14).

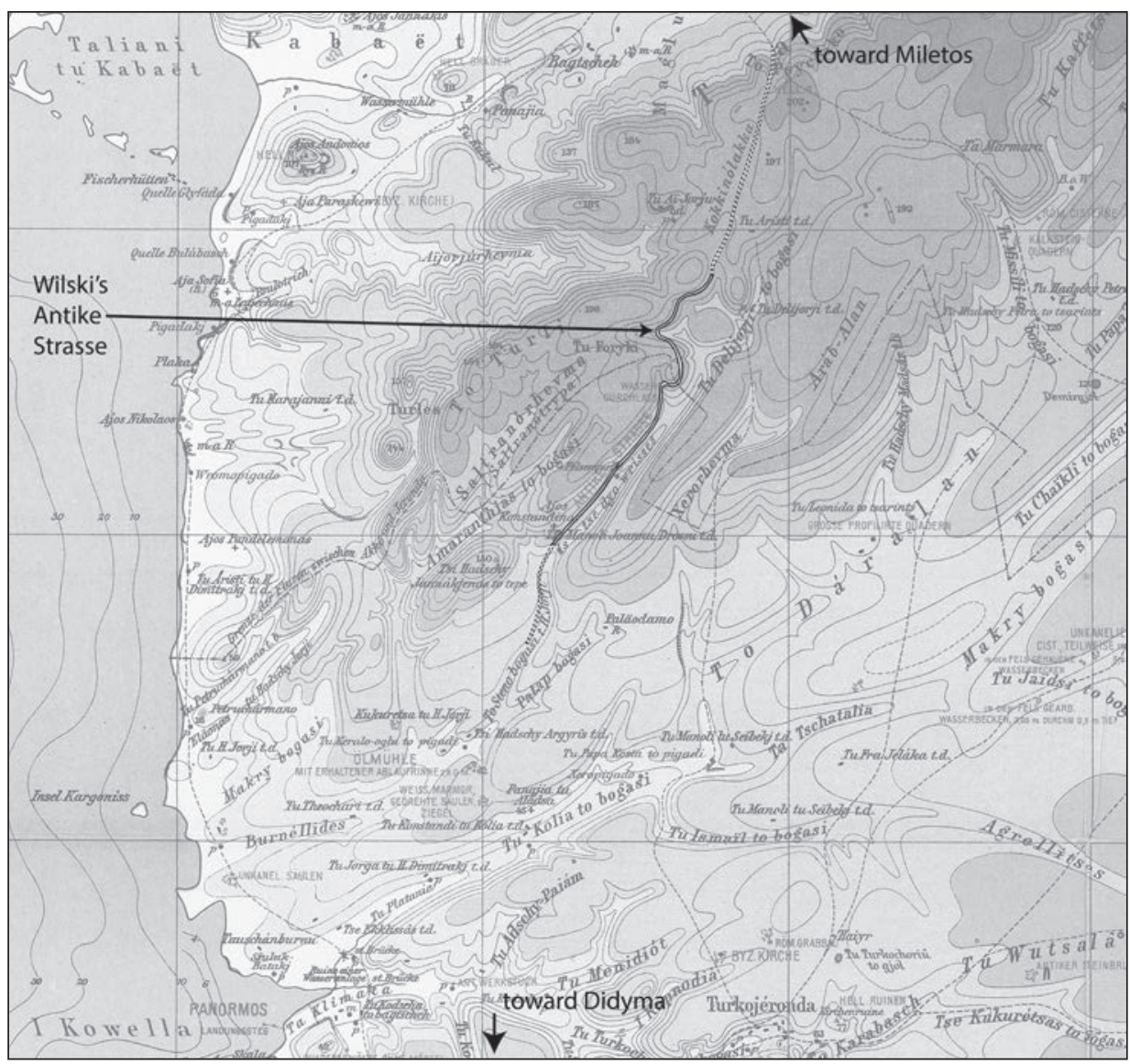

FIG. 2. Extract from Wilski's map, showing the Akron Hills and the area around Panormos; the Antike Strasse is highlighted and labeled (modified from Wilski 1906). 
more or less identical to the main modern coastal road (as of today). ${ }^{16}$

This began to change following the discovery of the Molpoi inscription, on 26 November 1903, ${ }^{17}$ in the Sanctuary of Apollo Delphinios at Miletos. ${ }^{18}$ This long Greek text, first transcribed and translated to German by Ulrich von Wilamowitz-Moellendorff and Albert Rehm, included a detailed description of a cult

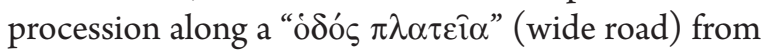
Miletos across the Akron Hills and thence to Didyma, and it mentioned different stations where rituals had to be performed along the way. ${ }^{19}$ It seems it was von Wilamowitz-Moellendorff who first assumed that this "wide" road of the Molpoi should be equated with the "sacred" road of the Sacred Gate inscription, a small and innocuous interpretative leap that was nonetheless to have deep consequences for the understanding of the Sacred Way. ${ }^{20}$

It was only in 1986, however, after the renewal of German explorations at Didyma and the surrounding area from the late 1970s under Klaus Tuchelt, that Karin B. Gödecken presented the first explicit reconstruction for the physical route of the Sacred Way, based on a series of new and old archaeological finds and informed by the Molpoi inscription. ${ }^{21}$ The discovery ca. 1901 of a seated figure with a votive inscription near the southern end of Wilski's Antike Strasse, located directly next to a rock spring, ${ }^{22}$ led to the interpretation

\footnotetext{
${ }^{16}$ Wiegand 1901, 913: "Besonders hervorgehoben sei, dass sich der Verlauf der heiligen Strasse nach Didyma aus den Thalsenkungen, aus der Lage begleitender Grabmonumente und dem Funde zweier archaischer, thronender Marmorfiguren beim Cap Plaka mit ziemlicher Sicherheit schon jetzt festlegen lässt" (It should be emphasized that the course of the sacred road to Didyma from the valley bottoms, from the position of accompanying tomb monuments and the finds of two archaic, enthroned marble figures near Cape Plaka, can already be determined with great certainty). Cape Plaka, according to Wilski's map, lies on the coast in the area of the modern artificial Balikçi Liman (fishing port). Wiegand did not publish a map showing his understanding of the route.

${ }^{17}$ As documented in the excavation notebook (Wiegand 1903-1904, 47; cited in Herda 2006, 21 n. 71).

${ }^{18}$ This inscription, or rather the text it contains, is sometimes known as the Molpoi statutes or Molpoi-Satzungen.

${ }^{19}$ von Gerkan 1935.

${ }^{20}$ von Wilamowitz-Moellendorff 1906, 636: “Didyma selbst war durch den unbequemen heiligen Weg über das Gebirge direkt mit Milet verbunden" (Didyma itself was connected directly with Miletos via an inconvenient sacred way across the hills).

${ }^{21}$ Gödecken 1986, 224.

${ }^{22}$ The statue fragment was found 11 March 1901; the rock
}

of the remains of an architectural complex with a religious function. ${ }^{23}$ This complex has become known as the Sanctuary of the Nymphs. In 1984, Gödecken had identified another building complex in the Stephania/ Akron Hills along Wilski's Antike Strasse that she dated on the basis of surface ceramic, tiles, small finds, and sculptural fragments to the Archaic period. ${ }^{24}$ The subsequent excavations by Tuchelt revealed sphinx sculptures and broken votive vessels of the Late Archaic era; these finds suggested a religious purpose for this building complex, which came to be known as the Archaic Cult Complex..$^{25}$ In the 1980s, Tuchelt and his team also excavated a wide area to the northwest of the Temple of Apollo at Didyma. Here they uncovered a $30 \mathrm{~m}$ long stretch of paved street flanked by the foundations of a series of roadside buildings. ${ }^{26}$

The evidence from these various archaeological investigations and epigraphic sources were finally synthesized comprehensively by Peter Schneider in 1987, in an article that went into considerable detail to establish the full route of the Sacred Way from Miletos to Didyma. ${ }^{27}$ Schneider, following Gödecken, argued that the existence of the apparently cult-focused finds along with the material remains of a long-lived road crossing the Akron Hills allowed us to link incontrovertibly Wilski's Antike Strasse with the "wide road" of the Molpoi inscription and the "sacred way" of Trajan's Sacred Gate inscription(s). Schneider took it as a given that Tuchelt's stretch of paved street near Didyma, and thus the section first described by Gell as a sacred way, was part of the same road. These assumptions, allied with a review of the topography of the uncertain segments of road, such as the segment between the Sanctuary of the Nymphs and the paved road at Didyma, allowed Schneider to construct a route (digitized and shown on fig. 3) that, in the absence of alternative accounts, has served as the standard reference for the Sacred Way. As a result, almost 30 years later, this route

\footnotetext{
spring is marked on Wilski's map next to "Ajos Konstandinos" (see fig. 2). Schneider (1987, 110) reports that water was still flowing from the spring; see also Ehrhardt 1993, 5-7.

${ }^{23} \mathrm{~A}$ possible cultic function of the structure has been suggested on the basis of several architectural fragments (including an archaic cymation) probably originating from an altar or a temple-like building (Bumke et al. 2000, 95-6).

${ }^{24}$ Gödecken 1986, 220-23.

${ }^{25}$ Tuchelt et al. 1996, 231-41.

${ }^{26}$ Tuchelt 1987, 78-9.

${ }^{27}$ Schneider 1987, 102.
} 


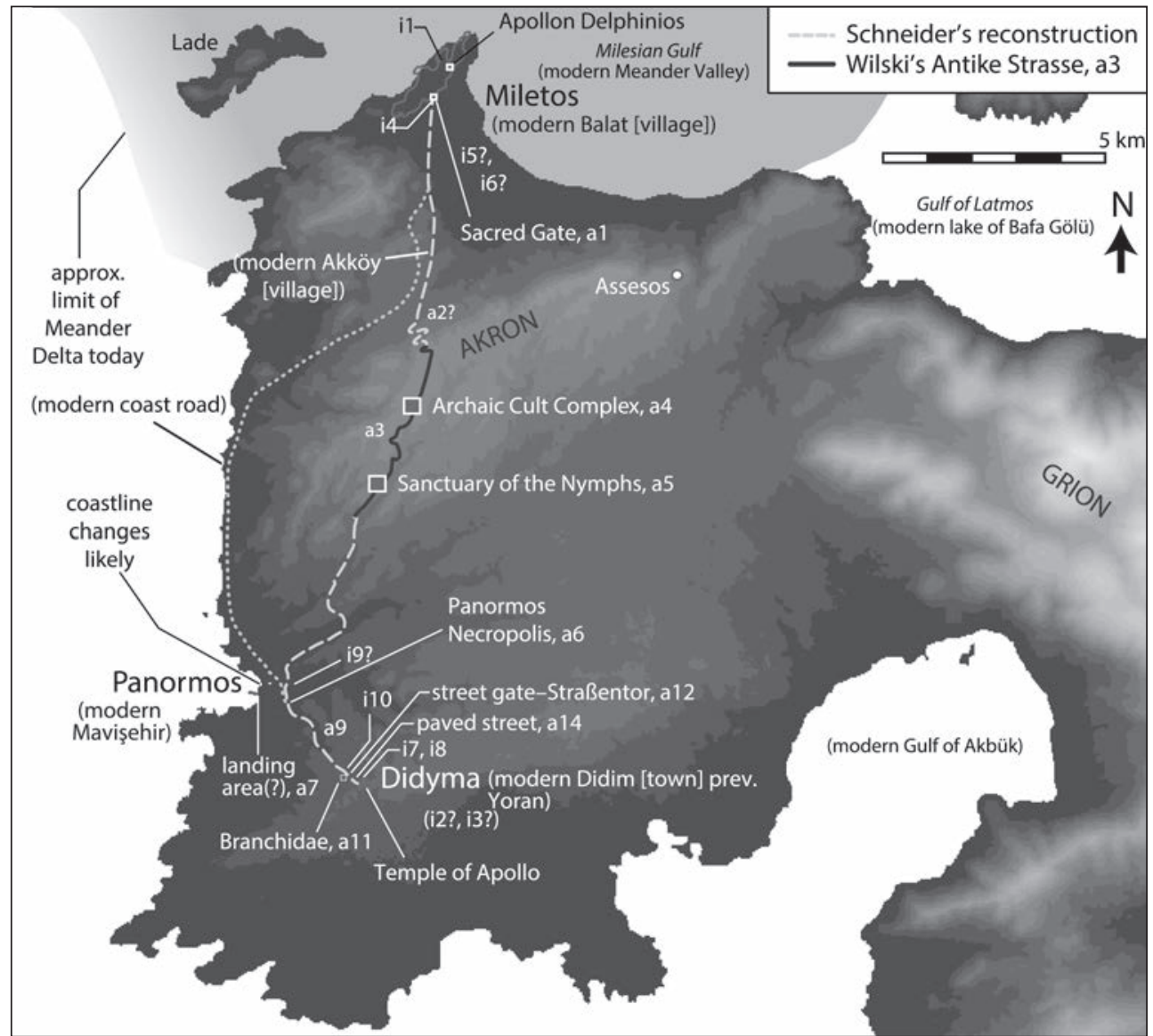

FIG. 3. Topographic map of the Milesian Peninsula, showing major locations (Miletos, Didyma, Panormos), Wilski's Antike Strasse (solid dark gray line), Schneider's orthodox reconstruction of the additional parts of the route of the Sacred Way (dashed light gray line), the modern coast road between Akköy and Didim (dotted light gray line), and the findspots of key inscriptions ("i") and other archaeological remains ("a") (drawing by T. Wilkinson and A. Slawisch).

formed the basis of the modern hiking path conceived and executed by the local government.

\section{VISIONS OF THE SACRED WAY: IMAGES, ORTHODOXIES, AND DOUBTS}

Since being uncovered in the 1980s, the excavated section of paved street at Didyma has become a visual shorthand for the Sacred Way as a whole (fig. 4 , left). ${ }^{28}$ This is, no doubt, because it is so easily understandable as a road. Yet for several reasons, we should be cautious about taking this as our defining image of the Sacred

\footnotetext{
${ }^{28}$ This can be demonstrated with a Google image search using the terms "sacred way Didyma," "sacred way Miletos," or "sacred way Miletus," which all produce photographs of this paved section.
}

Way. If, as implied by the association with archaic building complexes in the Akron Hills, the road dates back to the Archaic era, then the limestone paving seems to be a relatively late development of the early second century C.E. Indeed, it seems that most ancient streets were never paved, which is one of the reasons that pre-Roman roads in particular are so difficult to identify. Something like Schneider's photograph (see fig. 4, right), taken in the opposite direction only a few hundred meters to the northwest, might give a slightly more realistic impression of how such an unpaved track might have looked for much of its history and for much of its route, although even here one sees traces of curbstones that may be late additions.

Schneider's photograph also highlights a visual conundrum in the relationship between road and sanctuary. Schneider makes much of the visibility of Didyma 

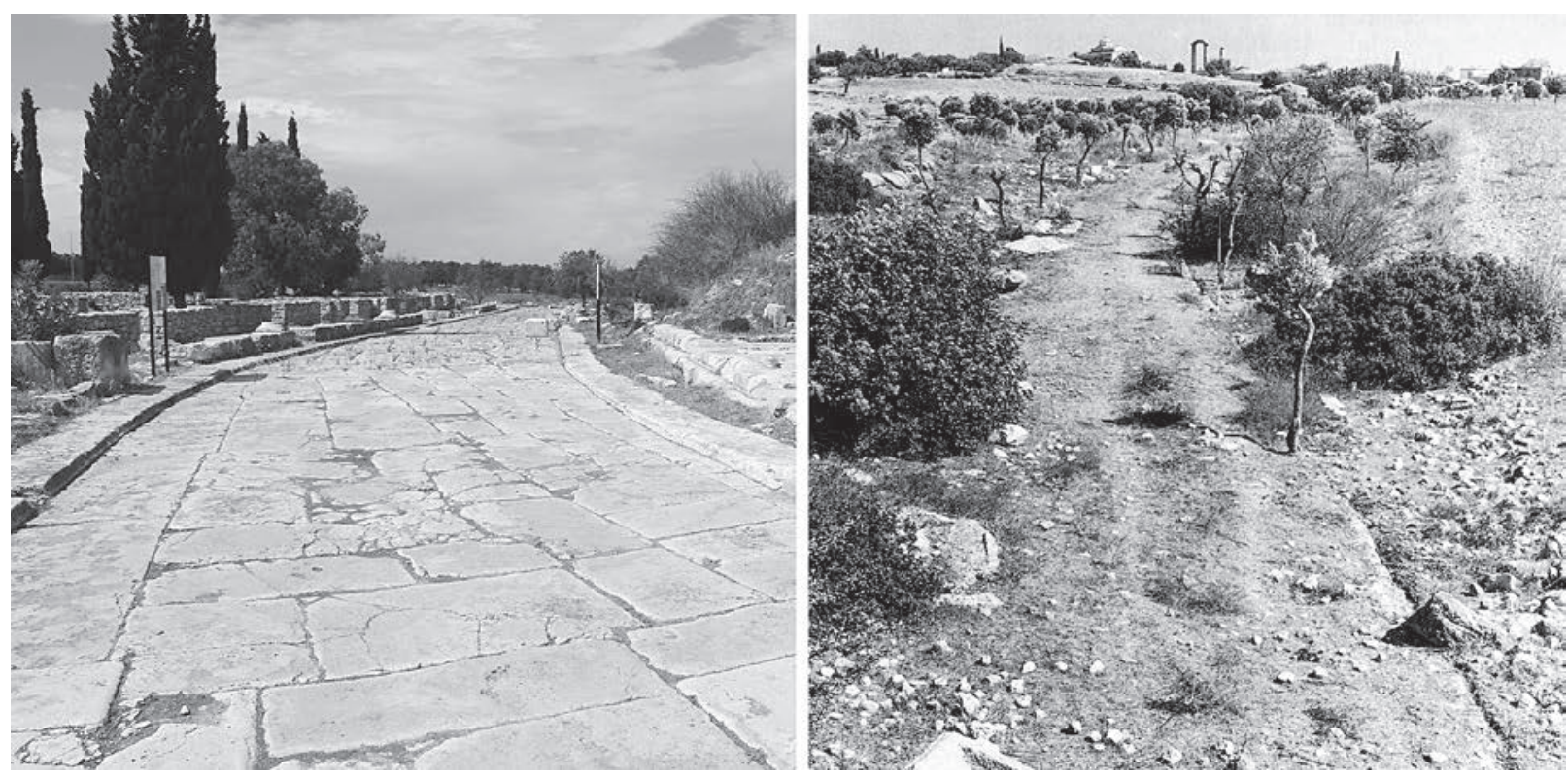

FIG. 4. Views of the Sacred Way: left, looking northwest along the paved road from Didyma toward Panormos in 2015 (T. Wilkinson and A. Slawisch; (C) Project Panormos); right, looking southeast along the Sacred Way toward Didyma, several hundred meters to the northwest of the section seen in the photograph at left (Schneider 1987, fig. 20).

or of Miletos from the road, especially from the Sanctuary of the Nymphs, marking the location of Didyma on the horizon on photographs in his article..$^{29}$ But in the immediate approach to the temple, along the uphill stretch from Panormos and for much of the section between the Sanctuary of the Nymphs and Panormos, little of the enormous building would have been visible until the very last $100-200 \mathrm{~m}$. Here it was finally revealed (as we see in Schneider's photograph), albeit at an angle that might still have hidden the altar area at the front of the temple. Since the temple and altar faced northeast, the road and its users traveling southeast from Panormos would have arrived at the northwest flank of the temple. To reach the altar and the front of the temple, a traveler must have turned toward the east and then again to the south.

Our modern concerns with the visibility of major monuments, ${ }^{30}$ important to us as owners of a worldview that prioritizes the visual, ${ }^{31}$ may be misleading.

\footnotetext{
${ }^{29}$ Schneider 1987, figs. 13, 17.

${ }^{30} \mathrm{~A}$ very small selection from the vast range of studies devoted to visibility and viewsheds of ancient monuments include Thomas 1993; Llobera 2007; Williamson 2014.

${ }^{31}$ Heidegger (1977) characterized the discourse of modernity as distinctively concerned with conceiving the world visually (i.e., the era of the "world-as-picture").
}

Concealment and careful revelation may have been an intentional part of the architectural theatrics for the ancient inhabitants or designers. We should remember that aside from the Temple of Apollo itself (the foundations of the currently visible temple are Late Classi$\mathrm{cal}$, and the superstructure is a Hellenistic and Roman construction), our knowledge of the overall layout, topography, and architectural structure of the sanctuary at Didyma at any period remains rather poor. The recent discoveries of a theater (to the south of the Temple of Apollo) and the substantial foundations under the modern mosque that may or may not represent those of a temple of Artemis hint at a settlement far more complex than the modern picture of the lonely standing temple nestled in a small village might suggest. ${ }^{32}$ We also remain unclear about the motivations behind the orientation of Greek temples that might have forced such an odd disjunction between the temple entrance and the path from the sea. Astrological (both solar or stellar) alignments have been widely suggested, ${ }^{33}$ but the various incarnations of the Temple

\footnotetext{
${ }^{32}$ For a report on the newly discovered theater and foundations that may be that of a temple of Artemis, see Bumke et al. 2015a, 119, 125-46.

${ }^{33}$ Boutsikas and Ruggles 2011.
} 
of Apollo at Didyma ${ }^{34}$ cannot easily be assigned to any particular astrological event or configuration.

Schneider's reconstruction of the route has, in effect, become the orthodox view of the Sacred Way, one that is little questioned today. ${ }^{35}$ From the beginning, however, and as Schneider himself acknowledged, there remain considerable gaps in the evidence that leave some sections of the route uncertain. Moreover, Schneider glosses over or ignores some potentially serious snags. The length of Schneider's reconstructed route measures approximately $19 \mathrm{~km}$, somewhat more than the $16.3 \mathrm{~km}$ claimed in the Trajanic milestone found at Didyma. ${ }^{36}$ This discrepancy remains difficult to resolve. Schneider also did not consider the potential significance of possible geomorphological changes in the Panormos region, a factor later discussed by Tuchelt. ${ }^{37}$ Perhaps most problematic, however, is the way that textual and archaeological evidence of different periods has been compressed or elided to facilitate a uniform concept of the Sacred Way. This process has involved an accumulation of small interpretative leaps made by scholars over the last 200 years, among different epigraphic texts and between textual references to ancient locations and their possible archaeological correlates. The danger is that the resulting compressed reconstruction is anachronistic, approximating something that never existed in the past. The untangling of the dating of these different classes of evidence, epigraphic and archaeological, and their relationship to successive human and natural landscapes is therefore an essential part of reassessing the character and diachronic development of the Sacred Way.

\footnotetext{
${ }^{34}$ See, e.g., Herda 2006, fig. 21.

${ }^{35}$ E.g., Agelidis (2012, 87 n. 15$)$ asserts that "Die Heilige Straße von Milet nach Didyma verlief über Jahrhunderte auf derselben Trasse" (The Sacred Road from Miletus to Didyma has followed the same route for centuries); Herda similarly accepts Schneider's reconstruction of the way as static (Herda 2006, 178, 371-72, 527, 537, figs. 7, 9).

${ }^{36}$ This distance also does not factor in the additional anisotropic distance from topographic slope. Schneider 1987, 128 "Die tatsächliche Länge des bisher beschriebenen Prozessionsweges vom Heiligen Tor in Milet bis zum 'Straßentor' von Didyma muss jedoch weit mehr betragen, da bereits die Luftlinienverbindung der Hauptpunkte dieser Trasse nach der Karte von P. Wilski ca. 16,5 km mißt" (The actual length of the processional route from the Sacred Gate in Milet to the "Straßentor" of Didyma must, however, be much more, since the direct as-thecrow-flies line between the main points of this route according to the map of P. Wilski is about $16.5 \mathrm{~km}$ ).

${ }^{37}$ Tuchelt 2000,352 n. 140.
}

REEXAMINING THE EPIGRAPHIC EVIDENCE: CHRONOLOGY AND TERMINOLOGY

So far, no inscriptions dating to the Archaic or Classical era have been found that refer to any "sacred way," to any processions, or even to any roads between $\mathrm{Mi}$ letos and Didyma. Of course this may partly be simply a factor of the overall paucity of archaic or classical inscriptions across the peninsula, whether a result of post-500 B.C.E. destructions by the Persians or simply because the stone-based epigraphic habit was at a lower intensity in the Archaic and Classical periods than during the subsequent Hellenistic or Roman eras. Nonetheless, it is worth being open to the idea that the absence of references to a sacred way could mean that the archaic inhabitants of the prosperous Milesian peninsula had no sacred way, or, if something approximating a sacred way did in fact exist in praxis, they did not describe it as such.

\section{The Molpoi Inscription: Dating of the Text and} References to the "Wide Road"

While no inscriptions date directly to the Archaic era, many scholars have pointed to a text from one particular later Hellenistic monument as being of possible archaic composition. The inscription on the Molpoi stele (table 1, no. i1; online appx. 1, table 1, no. i1 on AJA Online; fig. 5a), found at the Sanctuary of Apollo Delphinios in Miletos, is a long and sometimes ambiguous set of statutes or protocols pertaining to rituals for a religious and political group who self-identify as the Molpoi. ${ }^{38}$ To follow Herda's reading, it includes preparations for a new year's festival at the Sanctuary of Apollo Delphinios (lines 6-18, 23-5), preparations for feasts for Apollo and Basileus (lines 20-3), instructions for a procession to Didyma (lines 18-20, 25-31), and instructions for the appropriate division of roles and of offerings for those involved with the procession and/or sacrifice. ${ }^{39}$

The section that refers to a procession along the "wide road" (lines 25-30) records a sequence of stations or sanctuaries at which rituals were performed (including the singing of paians). ${ }^{40}$ It reads as follows: ${ }^{41}$

\footnotetext{
${ }^{38}$ For further discussion of the Molpoi, see Herda 2006, 35 (with references).

${ }^{39}$ Herda 2006, 427.

${ }^{40}$ Herda 2006, 106-12.

${ }^{41}$ Text following Herda 2006, 10.
} 
TABLE 1. Inscriptions relevant to the Sacred Way. For detailed information and references, see online appendix 1, table 1.

\begin{tabular}{|c|c|c|c|c|}
\hline No. & Name (Language) & Manufacture Date & Discovery Date (Find Context) & $\begin{array}{l}\text { Alternative } \\
\text { Identifiers }^{\mathrm{a}}\end{array}$ \\
\hline i1 & $\begin{array}{l}\text { Molpoi inscription/ } \\
\text { Molpoi statutes (Greek) }\end{array}$ & $\begin{array}{l}\text { ca. } 200 \text { B.C.E. (composition } \\
530-200 \text { B.C.E.?) }\end{array}$ & $\begin{array}{l}1903 \text { (Miletos, Temple of } \\
\text { Apollo Delphinios, in situ) }\end{array}$ & - \\
\hline $\mathrm{i} 2$ & $\begin{array}{l}\text { gravestone for Bitto or } \\
\text { Bittion (Greek) }\end{array}$ & ca. 200 B.C.E. & ca. 1895 (Didyma) & Did. II, no. 537 \\
\hline i3 & $\begin{array}{l}\text { building inscription } \\
\text { (Greek) }\end{array}$ & ca. $200-175$ B.C.E. & 1896 (Didyma) & Did. II, no. 40 \\
\hline $\mathrm{i} 4$ & $\begin{array}{l}\text { Sacred Gate inscription } \\
\text { (Latin) }\end{array}$ & 101/2 C.E. & $\begin{array}{l}1873 \text { (Miletos, in situ at } \\
\text { Sacred Gate) }\end{array}$ & $\begin{array}{l}\text { Mil. II, 3, no. } \\
402\end{array}$ \\
\hline i5 & Trajan’s works (Greek) & 101/2 C.E. & $\begin{array}{l}1997 \text { (secondary usage in } \\
\text { Akyeniköy?) }\end{array}$ & E/W, Milet 2 \\
\hline i6 & $\begin{array}{l}\text { Trajan's works, two-sided } \\
\text { stele (bilingual) }\end{array}$ & 101/2 C.E. & 1901 (Miletos) & $\begin{array}{l}\text { Mil. I, 7, no. } \\
272 \mathrm{a}, \mathrm{b}\end{array}$ \\
\hline i7 & $\begin{array}{l}\text { Trajan's works, stele } \\
\text { fragment (Latin) }\end{array}$ & 101/2 C.E. & 1909 (Didyma) & Did. II, no. 55 \\
\hline i8 & $\begin{array}{l}\text { Trajan's works, stele } \\
\text { fragment (Greek) }\end{array}$ & 101/2 C.E. & 1909 (Didyma) & Did. II, no. 56 \\
\hline i9 & $\begin{array}{l}\text { Trajan's works, two-sided } \\
\text { stele (bilingual) }\end{array}$ & 101/2 C.E. & 1972 (Panormos) & $\begin{array}{l}\text { Did. II, nos. } \\
55 \text { (Latin), } 56 \\
\text { (Greek) }\end{array}$ \\
\hline i10 & $\begin{array}{l}\text { milestone, Trajanic (Latin } \\
\text { and Greek) }\end{array}$ & 101/2 C.E. & $\begin{array}{l}1909 \text { (Didyma, near the } \\
\text { Straßentor) }\end{array}$ & Did. II, no. 57 \\
\hline i11 & $\begin{array}{l}\text { milestone, Julianic (Greek } \\
\text { with Roman numerals) }\end{array}$ & 362/3 C.E. & unknown, 1909? (unknown?) & $\begin{array}{l}\text { Did. II, no. 60; } \\
\text { Fr, no. 123(B) }\end{array}$ \\
\hline
\end{tabular}

${ }^{a}$ The alternative identifiers reflect the way these inscriptions have often been referred to in past publications. They are provided here to aid the reader to navigate the literature more easily (Did. II = Rehm 1958; Mil. I = Rehm 1914; Mil. II = von Gerkan 1935; E/W = Ehrhardt and Weiß 2011; Fr = French 2014).

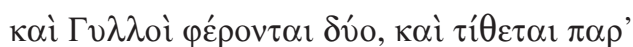

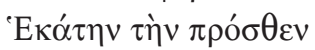

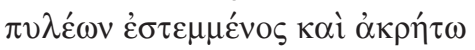

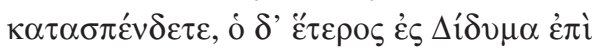

$\theta \dot{\rho} \rho \alpha \varsigma \tau i \dot{\theta} \varepsilon \tau \alpha 1$. $\tau \alpha \hat{\tau} \tau \alpha \delta \dot{\varepsilon} \pi \mathrm{o} \eta \dot{\sigma} \sigma \alpha \nu \tau \varepsilon \varsigma$

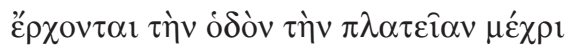

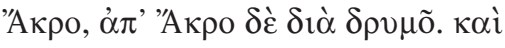

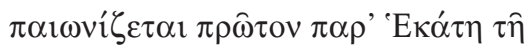
$\pi \rho{ }^{\prime} \sigma \theta \varepsilon v \pi v$

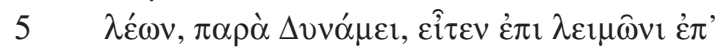

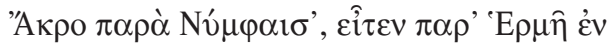

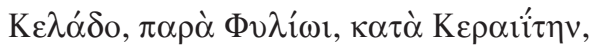

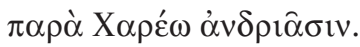

The interpretation of this text has proven very challenging, and this is not the place to attempt a new English translation. Herda provides the most up-to-date and complete interpretation in German, and our discussions here rely heavily on his particular reading of this section. ${ }^{42}$ To paraphrase: ${ }^{43}$ Starting with a sacrifice at the Delphinion in Miletos, two Gylloi ${ }^{44}$ are placed at [the sanctuary of?] Hekate, before the doors, ${ }^{45}$ and at

\footnotetext{
${ }^{42}$ The segment of the inscription relating to the procession is one of the least contested parts of Herda's interpretation of the stele; cf. Parker 2008; Chaniotis 2010.

${ }^{43}$ Transliterated place-names appear in italics; brackets enclose clarifications added to make the likely meanings of placenames more apparent.

${ }^{44}$ Sacred boundary stones. Cf. Herda (2006, 249-59, esp. 259), who coins the term "heilige Grenzsteine."

45 "Before the doors" ( $\tau \grave{\eta} v . . . \pi v \lambda \dot{\varepsilon} \omega v)$ implies a location outside the city wall of Miletos. The Hekate could represent a statue or an architectural structure (Herda 2006, 282-85).
} 


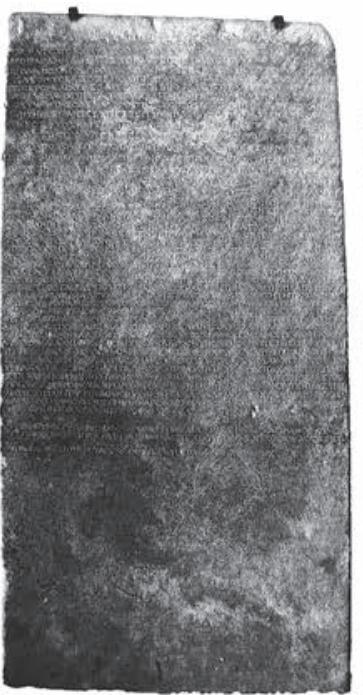

a

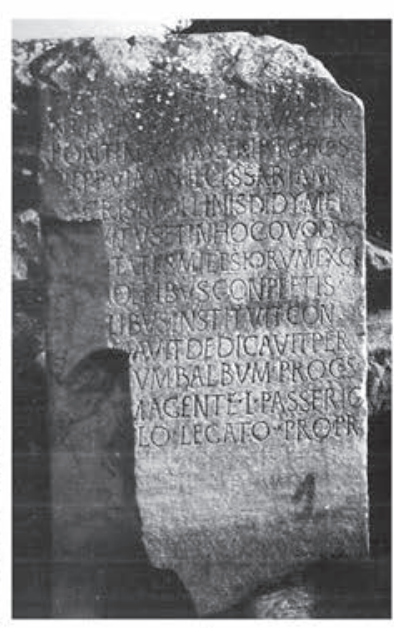

b

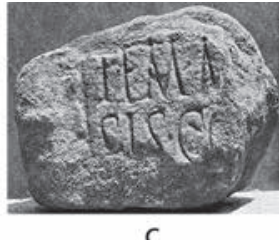

C

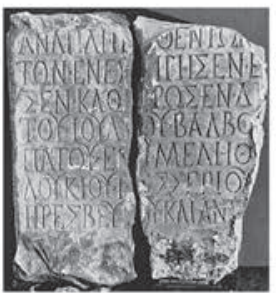

e

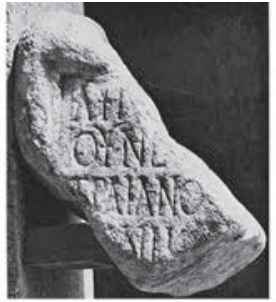

d

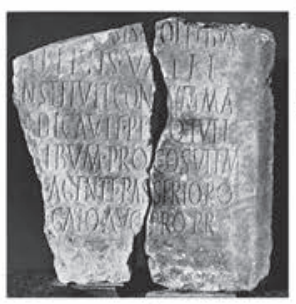

f

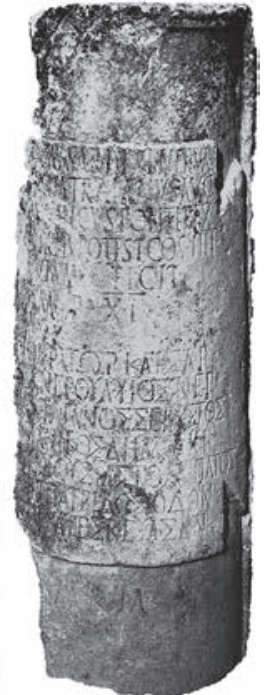

g

FIG. 5. Inscriptions relating to the Sacred Way (see table 1; online appx. 1, table 1): a (i1), Molpoi statutes (Herda 2006, 513); $b$ (i4), Sacred Gate inscription, Latin, describing Trajan's works, Miletos (von Gerkan 1935, fig. 13); c (i7), apparently a fragmentary Latin version of i4, Didyma; $d$ (i8), apparently a fragmentary Greek version of i4, Didyma (Tuchelt 1973, pls. 6.2, 6.3); $e, f($ i9), both sides of, apparently, a fragmentary bilingual version of i4, Didyma (Tuchelt 1973, pls. 7.1, 7.2); g(i10), Roman milestone, written in Greek, from Didyma (Tuchelt 1973, pl. 6.1).

Didyma. Participants then take the "wide road" (ódòv $\tau \eta \dot{\nu} v \lambda \lambda \alpha \tau \varepsilon \tilde{\varepsilon} \alpha$ ) to the Akron Hills through the forest, singing cultic songs at a series of stations: first at the Hekate before the gates [of Miletos]; then at Dynamis; then at the grassland on the Akron Hills where the Nymphs are; then at [the monument of?] Hermes at [the sanctuary of?] Kelados; ${ }^{46}$ at [a sanctuary of?] Phylios in the area of Keraiites; ${ }^{47}$ at the statues of Chares; before arriving at Didyma.

Based primarily on the letter style, the date of manufacture for the Molpoi stele itself has been conventionally assigned to soon after 200 B.C.E. ${ }^{48}$ However, von Wilamowitz-Moellendorff and later Rehm also maintained that the text itself contains older sections, and they suggested that it represented a second-century copy of a lost fifth- or sixth-century inscription or text. ${ }^{49}$ Herda has subsequently made use of the putative

\footnotetext{
${ }^{46}$ Herda 2006, 302-10.

47 "The horned one," according to translation in Herda 2006, 249-350.

${ }^{48} \mathrm{~A}$ summary of the arguments over the date is to be found in Herda 2006, 15-20; see also Rhodes 2006.

${ }^{49}$ von Wilamowitz-Moellendorff 1904, 619-20: "Abschrift eines älteren Dokumentes, das selbst aber auch nicht einheitlich
}

archaizing sections of the Molpoi inscription as a window onto cult practices of the Archaic period, arguing that they were sustained continuously at least from the sixth until the second century B.C.E. ${ }^{50}$

A number of scholars have attempted to correlate the stations of the Molpoi with archaeologically attested structures or other landmarks between Miletos and Didyma and thus to create a definitive map of the route of this procession (summarized in table 2; see online appx. 1, table 2). ${ }^{51}$ The mention of nymphs enables an association with the complex now known as the Sanctuary of the Nymphs, not least because of an archaic

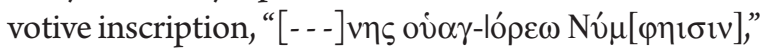

war" (copy of an older document, which itself was not uniform); cf. Rehm 1914.

${ }^{50}$ Herda has published extensively on the Molpoi statutes (see esp. Herda 2006). For the dating of the transcript, see Herda 2006, 15-20. For the possible archaic sections, cf. Rehm 1914, 277-84; Herda 2006, 226. That this inscription proves the continuity of the procession for more than four centuries tends to be assumed (Sokolowski 1955, 129-35; Ehrhardt $2003,12)$. Continuity is not reflected in the scant archaeological record, however; see, e.g., Slawisch 2009.

${ }^{51}$ Gödecken 1986; Schneider 1987; Herda 2006, 259-65. 
TABLE 2. Processional stations implied or mentioned on the Molpoi inscription and their possible archaeological correlates (following Herda 2006).

\begin{tabular}{|c|c|c|}
\hline Station & English Translation & Possible Location or Correlate \\
\hline [implicit] & - & Altar of Apollo, Delphinion, Miletos \\
\hline 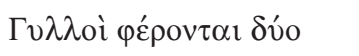 & Gylloi, placed at gate & near Sacred Gate at Miletos (a1) \\
\hline${ }^{` E \kappa \alpha ́} \tau \eta \nu$ & the Hekate & unknown \\
\hline 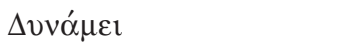 & Dynamis & unknown \\
\hline 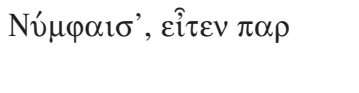 & $\begin{array}{l}\text { grassland on the Akron Hills } \\
\text { where the Nymphs are }\end{array}$ & Sanctuary of the Nymphs (a5) \\
\hline 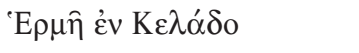 & Hermes in Kelados & unknown \\
\hline 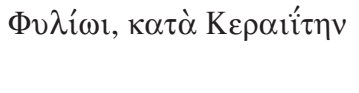 & $\begin{array}{l}\text { Phylios in the area of Keraiites } \\
\text { (the horned) }\end{array}$ & unknown \\
\hline 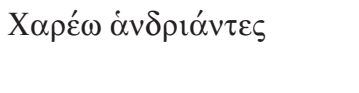 & the statues of Chares & $\begin{array}{l}\text { Branchidae? (a11, but location of statues may have } \\
\text { changed) }\end{array}$ \\
\hline [implicit] & - & Altar of Apollo, Didyma \\
\hline
\end{tabular}

read as "son of Euargoras, [to the] Nym[phs]," 52 found on a seated figure there (the figure itself is now lost). The sanctuary seems to have been in use most intensively during the Hellenistic era, however. ${ }^{53}$ The "statues of Chares" may also relate to the group of seated figures known as the Branchidae, as discussed further below. The start and end points (i.e., the Sanctuary of Apollo Delphinios at Miletos and Temple of Apollo at Didyma) are implicit, but no other secure correlations can be made.

The Molpoi inscription does not-and this is important to emphasize - contain any mention of a "sacred way." Nonetheless, the references to the sequence of geographic stations have been eagerly interpreted by Schneider, Herda, and many others as representing an echo of the route of the Sacred Way as it existed in the Archaic period. This article is not the place to review the evidence for or against cultural, demographic, or economic continuity during the fifth century B.C.E. at Miletos in detail, ${ }^{54}$ but it is worth highlighting the

\footnotetext{
${ }^{52}$ Ehrhardt 1993, 6; Herda 2006, 293 n. 2090.

${ }^{53}$ A survey followed by an excavation at the Sanctuary of the Nymphs was undertaken in 1994; the report was published in 2000 (Bumke et al. 2000). The material from the survey shows a preponderance of discarded pottery from the Hellenistic period (Bumke et al. 2000, 64); architectural fragments were dated to the Archaic, Hellenistic, Roman, and Byzantine periods (Bumke et al. 2000 64-6).

${ }^{54}$ The collapse and regeneration of Miletos after the destruc-
}

difficulty of using the Molpoi stele to reconstruct the social or geographic history of the sixth century given the extent of disruption caused by 20 years of wars and especially the Persian sack of Miletos in 494 B.C.E. after the Battle of Lade. One of the striking aspects of the Molpoi text, as Chaniotis noted in a review of Herda's treatment of the topic, ${ }^{55}$ is just how difficult it is to interpret. The almost willful obscurity of its content and its generally mystifying tone seem to be part of an intentional rhetorical effect. Whether or not the second-century sponsors of the Molpoi stele drew directly on earlier texts or oral information about earlier practices, it is very plausible that they were laying claims of antiquity for the practices described to bestow authority and authenticity on the practitioners of such processions. Such a strategy_-providing recycled, false, or massaged antiquity for traditions - is typical for many projects of political legitimation, a phenomenon that Hobsbawm called an "invented tradition." 56 Such traditions may of course draw on shared memory of the past (total fabrication is difficult), ${ }^{57}$ but many

tion of the city by the Persians forms the thrust of an extended monograph based on the evidence relating to Ionia in the fifth century B.C.E., currently in preparation by A. Slawisch.

${ }^{55}$ Chaniotis 2010.

${ }^{56}$ Hobsbawm 1992.

${ }^{57}$ See comments on the "past as a scarce resource" in Appadurai 1981. 
traditional practices are far younger than they claim. The intended audience of this inscription is unclear: perhaps it provided an explanation for visitors and the many new citizens who arrived in Miletos at this time as the city recovered from its long recession following the Ionian revolt. ${ }^{58}$ Opacity of meaning might well have strengthened the text's perceived authenticity as a historical document while simultaneously allowing a considerable degree of flexibility for new elites to dictate the actual practice of sacred rites. The historicity of the sequence of stations in the text is thereby necessarily open for discussion. From this perspective, the Molpoi stele should be seen very much as a propaganda tool of the early second century B.C.E., aimed at establishing the rights of the Molpoi through appeal to the past.

\section{Hellenistic Inscriptions: Gravestones and Road Maintenance}

Chronologically, the very earliest known direct reference to the existence of a sacred way appears to come from a fragmentary epigram on a gravestone, erected for Bit(to) or Bit(tion) and found reused in Didyma (see table 1, no. i2; online appx. 1, table 1, no. i2). This stele, dated on both prosopographical and letterform grounds to ca. 200 B.C.E., includes the phrase (line 5)

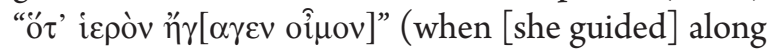
the sacred [way]). ${ }^{59}$ Potentially postdating this stele, another, much longer text, a building inscription found at Didyma (see table 1, no. i3; online appx. 1, table 1, no. i3), contains references to repairs to the "sacred way"

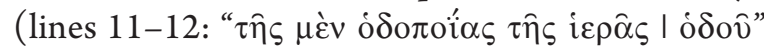
[for the remedial(?) maintenance of the sacred way])

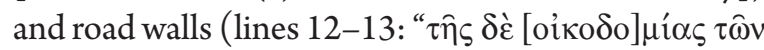

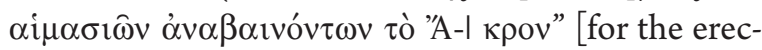
tion of dry-stone(?) walls going up to Akron]). ${ }^{60}$ This

\footnotetext{
${ }^{58}$ Köcke 2014.

${ }^{59}$ Günther 2014, 98-9. For discussion of the reconstruction of the text, see Peek 1971, 211-13, 213 n. 10; Herda 2006, 181 n. 1287.

${ }^{60}$ Herda (2006, 262 n. 1859), following Rehm (1958, 54), prefers to identify this reference "toward Akron" with the area between Miletos (rather than Didyma) and the Akron Hills, presumably south of Akköy. He makes this identification on the basis of the relative steepness of the landscape, which he argues would have required greater engineering, and because of the Milesian perspective of the procession in the Molpoi statutes. $\mathrm{He}$ admits, however, that the alternative perspective cannot be excluded. Given that this particular fragment is part of a corpus of building inscriptions concerning the temple at Didyma (and found in Didyma), it seems to us more likely that it refers to the road or area somewhere between Didyma and Akron.
}

inscription, dated primarily on the basis of the letterforms to the first quarter of the second century B.C.E., is one of several building inscriptions from Didyma. ${ }^{61}$ Whether the "sacred way" and "the walls going up to Akron" were considered parts of a single entity is not clear from the text. Similarly, the word " $\alpha i \mu \alpha \sigma i \alpha$ " [drystone(?) walls] could be read as referring to road walls, curbstones, or terrace walls. The subsequent lines (lines 13-16) specify the amount of work (measured in feet) and the price: a total of nearly 640 drachmas ${ }^{62}$ was paid by the temple for these construction works during the year under record, though these amounts probably did not include labor or material costs. ${ }^{63}$ Another reference to road works, potentially in a different location, later that same year (lines 22-8) hints that such road construction or maintenance might have been a regular task that the temple administration had to fund. ${ }^{64}$ The necessity for such work may well have had a relatively practical or logistical cause. In this era, substantial building works associated with the construction of the Late Classical/Hellenistic sanctuary were being undertaken at Didyma. The transportation of many large marble blocks installed as facing material in the temple must have had a considerable deleterious effect on the roads used to transport them, especially the one leading up from the harbor of Panormos, by which marble had been shipped from quarries in the Latmos. ${ }^{65}$

\footnotetext{
${ }^{61}$ While Rehm (1958, 50-1, no. 40) dated this inscription to the years $174 / 3$ B.C.E. on the basis of its similarities to an inscription with a contract between Herakleia and Miletos (Rehm 1914, no. 150), Herrmann (1997, 185-86, no. 150) points to the more recent research dating this inscription before 180 B.C.E.

${ }^{62}$ The actual costs are given very precisely, measured per length in feet; the total is given in drachma, obol, and chalkos (Rehm 1958, 56).

${ }^{63}$ Rehm 1958, 57.

${ }^{64}$ Comparable texts referring to road maintenance (with warmest thanks to Ludwig Meier for providing these parallels) include the following three examples from Eleusis and Delos: (1) IG $2^{2}$ 1673; Clinton 2005, 159, line 28 (ca. 327/6 B.C.E.): "Iron has been acquired for road-building"; Feyel 2006, 82, (cat. no. ÉL 155), 84 (cat. no. ÉL 173). (2) IG 122 159, lines 42-3 (281 B.C.E.): accounts of the hieropoioi from Delos, unspecified road works; Feyel 2006, 301 (cat. no. DÉL 656). (3) IG 112203 A, line 37 (269 B.C.E.): accounts of the hieropoioi from Delos, payment to the master road builder (Straßenbaumeister) Rhodôn of one drachma two obole, probably for the maintenance of the processional way; cf. Feyel 2006, 271 (cat. no. DÉL 453), lines 43-4 (on street cleaning); Feyel 2006, 302 (cat. no. DÉL 656).

${ }^{65}$ Several building inscriptions note the transportation of building materials via Panormos, which were presumably
} 
Roman Inscriptions: Trajan's Sacred Way Rebuilding Project

The next relevant epigraphic sources date three centuries later to the early second century C.E. The most complete of this group is the Sacred Gate inscription (see table 1, no. i4; online appx. 1, table 1, no. i4; fig. 1) mentioned above, uncovered in Miletos in 1873 (see fig. 5b), apparently in situ, in the doorway of the Younger Sacred Gate. ${ }^{66}$ This is complemented by five matching dedicational inscriptions (see table 1, nos. i5i9; online appx. 1, table 1, nos. i5-i9; fig. 5c-f), each of which represents a fragment or version of the same text or basic information in Greek, Latin, or both, in varying degrees of preservation. Two of these were found at Didyma; one was found near Panormos; and two were found in the environs of Miletos. None was recovered in situ; most had been reused in later buildings. There is a mixture of two-sided, presumably freestanding stelae with the Greek and Latin on opposite sides (i6, i9) and single-sided plaques that were likely affixed to the wall of an architectural structure (i4, i5, i7, i8). In a recent review of this group, Ehrhardt and Weiß have noted that the freestanding examples (i4, i5, i7, i8) were found between Miletos and Didyma and might be interpreted as way markers along the Sacred Way (e.g., at junctions or bridges). ${ }^{67}$ Though found apparently dislocated from their original contexts, ${ }^{68}$ the fragments of the two single-faced inscriptions at Didyma (i7, i8) might, as Rehm argued, have originally belonged to a gate complex at Didyma, perhaps at the so-called Straßentor (discussed further below) ${ }^{69}$ All the inscriptions are dated to Trajan's fourth year of reign (101/2 C.E.) and presumed to form part of a single building project. ${ }^{70}$

The text of the Sacred Gate and related inscriptions record what appears to be a substantial construction

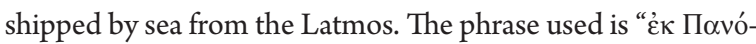

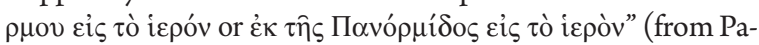
normos [Panormidos] to the sanctuary). For specific examples, cf. Rehm 1958, s.v. "Panormos."

${ }^{66}$ For the context, see von Gerkan 1935, 32-3. For the inscription itself, see Rehm in von Gerkan 1935, 133-34, no. 402; Herrmann 1997, 217, no. 402. On the date of the roadworks, see also Ehrhardt and Weiß 1995.

${ }^{67}$ Ehrhardt and Weiß 2011, 239-40.

${ }^{68}$ Their location when discovered ca. 1909—namely, above the east face of the Temple of Apollo-is apparently a secondary deposit.

${ }^{69}$ Rehm 1958, 104, nos. 55, 56; Tuchelt 1973, 25-6.

${ }^{70} \mathrm{Rehm}$ in von Gerkan 1935, 133-34, no. 402. For a discussion of the precise date, see Herrmann 1997, 217, no. 402; Ehrhardt and Weiß 2011, 248-49. The complete date is furnished by the associated milestone (i10).

project for the Sacred Way sponsored by the emperor Trajan. After listing Trajan's titles, and before naming Trajan's local agents, the Latin text of the Sacred Gate inscription (lines $4-10$ ) reads: ${ }^{71}$

\author{
viam necessariam \\ [s]acris Apollinis Didymei \\ intuitus et in hoc quoq(ue) \\ utilitates Milesiorum exci- \\ vallibus instituit con- \\ [sum] mavit dedicavit
}

$5 \quad$ sis collibus conpletis

[Trajan] began, executed and dedicated the road essential for the rites of the Didymeian Apollo, respecting the needs of the Milesians, with the cutting of hills and the filling of valleys.

Found not far from the Straßentor structure at Didyma, the bilingual milestone mentioned above-which furnishes us with the distance to Miletos as 11,000 passus (see table 1, no. i10; online appx. 1, table 1, no. i10; fig. 5g) —also explicitly salutes Trajan's sponsorship of the Sacred Way (i.e., he "made" or rather "built" the road). ${ }^{72}$ A later Roman milestone (see table 1 , no. i11; online appx. 1, table 1, no.i11), dated to ca. $362 / 3$ C.E., found reused, probably near Didyma, is often assumed to have been erected along the Sacred Way. ${ }^{73}$ Ehrhardt and Weiß suggested that the stone was part of a fourth-century renovation of the Sacred Way by Julian. ${ }^{74}$ However, the Greek text does not mention the Sacred Way directly, merely a distance, " $\mu \iota \lambda$ | IIII" (i.e., 4 Roman miles), to Miletos. ${ }^{75}$ Since it is equally possible

\footnotetext{
${ }^{71}$ Transliteration and German translation by Ehrhardt and Weiß 2011, 225.

${ }^{72}$ In Latin as "viam fecit," and in Greek as "ódòv I ípò̀v -

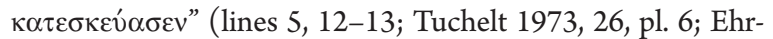
hardt and Weiß 2011, 234-36, no. C, fig. 12). The milestone still lay in its original findspot when we visited the area in 2015.

${ }^{73}$ Rehm 1958, 139: "Übrigens stammt sie eher aus Milet als aus Didyma. In Milet, nicht in Didyma, ist ja auch Julians Standbild aufgestellt gewesen." (In any case, it belongs rather to Miletus than Didyma. Julian's statue was erected in Miletus, not in Didyma.)

${ }^{74}$ Ehrhardt and Weiß 2011, 260 (with n. 137).

${ }^{75}$ If the distance was indeed just under $6 \mathrm{~km}$, and depending on which part of Miletos was considered the end point, the original site of this stone might alternately have been (1) the highest point along Akron (near the northern tip of Wilski's Antike Strasse), (2) a location to the west of modern Akköy, or (3) somewhere east of the modern village Akyeniköy (i.e., near the entrance to the other main pass across Akron that goes south past Assesos).
} 
that it could have been intended for one of the other roads to Miletos on the peninsula, it is difficult to rely on this inscription for discussion of the later history of the Sacred Way.

Trajan's involvement with such an apparently large program of restoration or reinvention of the Sacred Way was, of course, no idle or random act of imperial generosity or hubris. As Mitchell, among others, has pointed out, Trajan had a particular connection to Miletos since the oracle at Didyma reportedly predicted that Trajan would become emperor. ${ }^{76}$ These works, sponsored early in his reign, could be interpreted as an expression of gratitude to the political and religious elites of the Milesian Peninsula. The considerable political propaganda physically materialized by the building works and the inscribed eulogies was, therefore, a mutual performance of interdependence and alliance between the emperor and the elites of the Milesian Peninsula.

Ehrhardt and Weiß detect a slight difference in tone between the Latin and Greek versions: the Latin emphasizes the road's necessity in the sacred rites, whereas the Greek version explicitly mentions the Sacred Way. ${ }^{77}$ Striking is the claimed scale of the works in the Sacred Gate inscription, which involved the "cutting of hills" and the "filling of valleys" (lines 7-9; excisis collibus conpletis vallibus). This suggests a considerable degree of landscaping that one might expect to see evident in the archaeological record, to which we now turn.

\section{REEXAMINING THE ARCHAEOLOGICAL}

\section{EVIDENCE: POSITIVE AND NEGATIVE TRACES}

Tracing the physical remains of the Sacred Way represents a challenging task. As most archaeologists know, identifying roads is often problematic. Unless there are clear layers of paving, gravel, or other surface metaling, or clear curbing, recognizing a road surface in a trench section is almost as hard as identifying where to dig. While the paved sections at Didyma (a14) and behind the Sacred Gate at Miletos (a1) are clearly roads, can we securely identify them with the textually attested Sacred Way? To avoid the chronological compression of many periods into a single anachronistic understanding of the Sacred Way, we need to pay close attention to diachronic details. The following review of the archaeological remains, starting from

\footnotetext{
${ }^{76}$ Jones 1975; Ehrhardt and Weiß 1995, 331-43; Mitchell 2014.

${ }^{77}$ Ehrhardt and Weiß 2011, 238.
}

Miletos and finishing at Didyma, therefore focuses primarily on trenches cut through what has been assumed to be the Sacred Way. These are surprisingly few, and the resulting section drawings are often unsatisfying: the level of recording (even basic details of construction techniques, dimensions, and dating) has varied greatly. We also synthesize new information gleaned from work done since Schneider's reconstruction.

\section{Leaving Miletos: The Sacred Gate}

At Miletos, excavations under the direction of A. von Gerkan in 1908 (table 3, no. s1; online appx. 1, table 3 , no. s1) revealed a road measuring $11.40 \mathrm{~m}$ wide surfaced with large (limestone) paving stones and leading from the northern (i.e., inner side) of the Younger Sacred Gate (table 4, no. a1; online appx. 1, table 4, no. a1). There is no documentation to suggest that von Gerkan removed and excavated underneath the paving stones, so his dating of this installation to Trajan's reign is entirely based on the spatial association of the Sacred Gate inscription. By contrast, he did publish a schematic section from a sondage reportedly made in front of the Older Sacred Gate (fig. 6, inset), with a sequence of layers (labeled Hellenistic to Late Roman) presumed to be road surfaces with a slight camber (i.e., convex profile) set between two lines of curbstones spaced $5.48 \mathrm{~m}$ apart. ${ }^{78}$ Figure 6 shows a plan of the Sacred Gate area, where we have marked what we believe to be the approximate location of von Gerkan's sondage. This road was apparently bordered by several grave monuments, the larger of which are Roman or Hellenistic in date. ${ }^{79}$ Fragments of archaic ceramics and sarcophagi have been interpreted by Forbeck, among others, as indicating an earlier and perhaps continuous usage of the area as a necropolis. ${ }^{80}$ The dating of the earliest excavated level to the Hellenistic era seems to have been made primarily on the basis of the idea that the Older Sacred Gate was a Hellenistic construction. The architectural development of this gate area is not easy to understand, however, because the excavators recorded only architectural superposition and did not record associated finds that could confirm the building phases. ${ }^{81}$ In general there appear to have been several

\footnotetext{
${ }^{78}$ von Gerkan 1935, 30-2.

${ }^{79}$ Forbeck 1998, 150 (citing Watzinger and Gerkan).

${ }^{80}$ Forbeck 1998, 149-94 (for reference to archaic finds, see p. 151)

${ }^{81}$ von Gerkan $(1935,12)$ claimed, worryingly: "Absolute Datierungen hat die Ausgrabung für die Anlagen nicht ergeben, aber die baulichen Zusammenhänge der sehr zahlreichen
} 
TABLE 3. Archaeological sondages on the peninsula relevant to the Sacred Way, ordered by date of investigation. For detailed information and references, see online appendix 1, table 3.

\begin{tabular}{|c|c|c|}
\hline No. & Location (Trench Name $[\mathrm{s}]$ or Sondage Label $[\mathrm{s}]$ ) & Sondage Date (Dimensions) \\
\hline s1 & Sacred Gate, Miletos (sondage A) & 1903 (ca. 4 x 20 m) \\
\hline s2 & $\begin{array}{l}\text { northwest of Didyma, near paved street } \\
\text { (trenches I, II, III, IV, V, VI, VII, VIII, IX) }\end{array}$ & 1906 (mostly ca. 2 x 5 m) \\
\hline s3 & $\begin{array}{l}\text { near the Straßentor, Didyma } \\
\text { (trenches A, B, C, D, E, F, G, H, I, K) }\end{array}$ & $1938(?)$ \\
\hline s4 & paved street, Didyma (Südsondage) & $\begin{array}{l}1972(1.5 \times 5.5 \mathrm{~m} \text { across street, } 10 \times 1 \mathrm{~m} \text { along } \\
\text { street })\end{array}$ \\
\hline s5 & paved street, Didyma & ca. 1977-1983 (large open-area excavation) \\
\hline s6 & paved street, Didyma (Nordsondage) & $1983(3 \times 6 \mathrm{~m})$ \\
\hline s7 & Archaic Cult Complex, Akron Hills (trench TEM1) & $1985(4 \times 9 \mathrm{~m})$ \\
\hline s8 & $\begin{array}{l}\text { near Straßentor, Didyma (sondages SS } 87 / \mathrm{A} 1 \text {, SS } 87 / \mathrm{A} 2 \text {, } \\
\text { SS } 87 / \mathrm{B} 1 \text {, SS } 87 / \mathrm{B} 2 \text {, SS } 87 / \mathrm{C} \text {, SS } 87 / \mathrm{D} \text {, SS } 87 / \mathrm{F} \text {, SS } 87 / \mathrm{G} \text {, } \\
\text { SS } 87 / \mathrm{H} 1 \text {, SS } 87 / \mathrm{I} \text {, SS } 87 / \mathrm{K} \text {, SS } 87 / \mathrm{M} \text { ) }\end{array}$ & $\begin{array}{l}1987 \text { (various; SS } 87 / \mathrm{B} 1=3 \times 8 \mathrm{~m} \text {, SS } 87 / \mathrm{B} 2 \\
=3 \times 6 \mathrm{~m} \text { ) }\end{array}$ \\
\hline s9 & $\begin{array}{l}\text { Sanctuary of the Nymphs, Akron Hills } \\
\text { (sondage SS 94/18) }\end{array}$ & $1994($ ca. 2 x 6 m) \\
\hline s10 & $\begin{array}{l}\text { Sanctuary of the Nymphs, Akron Hills } \\
\text { (sondage SS 94/07) }\end{array}$ & $1994(3 \times 4 \mathrm{~m})$ \\
\hline s11 & $\begin{array}{l}\text { between paved stretch and temple, Knackfuß house, } \\
\text { Didyma (sondage HSA) }\end{array}$ & 2008 (ca. $2.6 \times 5$ m) \\
\hline s 12 & $\begin{array}{l}\text { around Mavişehir along projected route of Sacred Way } \\
\text { (museum sondages) }\end{array}$ & ca. 2011 (series of small sondages ca. 2 x $1 \mathrm{~m}$ ) \\
\hline s13 & Panormos Necropolis (sondage S1) & $2012(5 \times 2.5 \mathrm{~m})$ \\
\hline s14 & east end of paved stretch, Didyma & 2013 (small sounding) \\
\hline s 15 & between paved stretch and temple, Didyma & 2013 (small deep sounding) \\
\hline s16 & between mosque and temple, Didyma & 2014 (small deep sounding) \\
\hline
\end{tabular}

phases of reconfiguration. The Older Sacred Gate was certainly built first; the Younger Sacred Gate, added in the Late Hellenistic or Early Roman period, continued to be used long after the older southern structures had been dismantled. But the two structures may have been in use simultaneously for a while, forming a small irregular courtyard. Gerkan argued that the paving and inscription were a later Trajanic modification to the Younger Sacred Gate. Leaving aside the other uncer-

Änderungen geben eine so reiche Entwicklung, daß sie sich fast von selbst datiert" (The excavation [of the Sacred Gate area] did not yield absolute dates, but the structural connections of the very numerous changes give so rich a development that it almost dates itself). tainties, traces of any road predating the Hellenistic are conspicuously absent.

From Miletos to Akron: The Uncertain Course Around Akköy

Beyond the Sacred Gate, no concrete evidence of a road between Miletos and the Akron Hills has been recognized. In 1929, Wiegand identified the Sacred Way with an unpaved track snaking through the grave monuments on the incline above the Sacred Gate, ${ }^{82}$ but limited documentation makes it difficult to locate precisely all of the extramural Milesian necropoleis or the exact course of any road(s). The climb from Miletos

\footnotetext{
${ }^{82}$ Wiegand 1929, 9.
} 
TABLE 4. Reported archaeological structures, remains, and finds relating to or located near or along the possible route(s) of the Sacred Way, ordered north to south. For detailed information and references, see online appendix 1, table 4 .

\begin{tabular}{|c|c|c|c|}
\hline No. & Name(s) or Description & Construction Date(s) & Discovery Date \\
\hline a1 & $\begin{array}{l}\text { Sacred Gate, Miletos (including paved } \\
\text { street) }\end{array}$ & $\begin{array}{l}\text { Older Sacred Gate: Early Hellenistic(?); } \\
\text { Younger Sacred Gate: Hellenistic to Roman(?) }\end{array}$ & 1873 \\
\hline $\mathrm{a} 2$ & $\begin{array}{l}\text { terrace-like wall and stone scatters, } \\
\text { south slopes of Akron/Stefania Hills }\end{array}$ & undetermined & $1986 ?$ \\
\hline a3 & Wilski’s Antike Strasse, Akron Hills & ancient? & $1899 ?$ \\
\hline a4 & Archaic Cult Complex, Akron Hills & Archaic (sixth century B.C.E.) & 1984 \\
\hline a5 & $\begin{array}{l}\text { Sanctuary of the Nymphs/Quellbezirk, } \\
\text { Akron Hills }\end{array}$ & Archaic, Hellenistic, and Roman & 1901 \\
\hline a6 & Panormos Necropolis & Archaic & 2012 \\
\hline a7 & $\begin{array}{l}\text { Landungssteg/jetty with stone blocks } \\
\text { for mooring, at Panormos (modern } \\
\text { Mavişehir) }\end{array}$ & undetermined & ca. 1901 \\
\hline a8 & $\begin{array}{l}\text { sherd cluster (possible farmstead) in the } \\
\text { Subatağ } 1 \text { Mevkii area }\end{array}$ & Roman? & 2015 \\
\hline a9 & $\begin{array}{l}\text { sherd clusters (possible building?) } \\
\text { between Panormos and Didyma }\end{array}$ & Archaic? & 2015 \\
\hline a10 & series of stone sarcophagi near Didyma & Hellenistic/Roman? & 1812 \\
\hline a11 & $\begin{array}{l}\text { Branchidae (seated stone statues) near } \\
\text { Didyma }\end{array}$ & Archaic & 1812 \\
\hline a12 & $\begin{array}{l}\text { Straßentor (Street Gate) or Fundament } \\
\text { structure near Didyma }\end{array}$ & Archaic/Hellenistic/Roman(?) & 1907 \\
\hline a13 & $\begin{array}{l}\text { Grenzstein (cylindrical boundary stone) } \\
\text { near Didyma (found in Nordsondage) }\end{array}$ & Archaic(?) & 1983 \\
\hline a14 & $\begin{array}{l}\text { paved street at Didyma (locally, "the } \\
\text { Sacred Way") }\end{array}$ & Roman (Trajan?) & $1970 \mathrm{~s}$ \\
\hline a 15 & $\begin{array}{l}\text { grave monuments near Islamyoran } \\
\text { (northeast of Didyma) }\end{array}$ & Hellenistic/Roman & 1996-1998 \\
\hline
\end{tabular}

through the area occupied today by the modern village of Akköy to the top of the Akron Ridge is relatively steep, especially south of Akköy, climbing to approximately $180 \mathrm{~m}$. Schneider pointed to several structures (e.g., walls, stone scatters, and possible curbstones) visible on the surface in fields on the northern slopes of the Akron, and speculated that these were associated with different incarnations of the Sacred Way (see table 4, no. a2; online appx. 1, table 4, no. a2). ${ }^{83}$ Since, to our

\footnotetext{
${ }^{83}$ Schneider 1987, 105-6 n. 33.
}

knowledge, these were not systematically mapped and since no excavations have yet been undertaken in the area, little more can be said about this.

\section{In the Akron Hills: The Antike Strasse, Archaic Cult Complex, and Sanctuary of the Nymphs}

Beyond the crest of the Akron Ridge, in a valley descending to the south, Wilski traced a track that he called the Antike Strasse (see table 4, no. a3; online appx. 1, table 4, no. a3; fig. 2) on the basis of two broken lines of curbstones or terrace walls. This has come to be equated with the Sacred Way. He did not excavate 


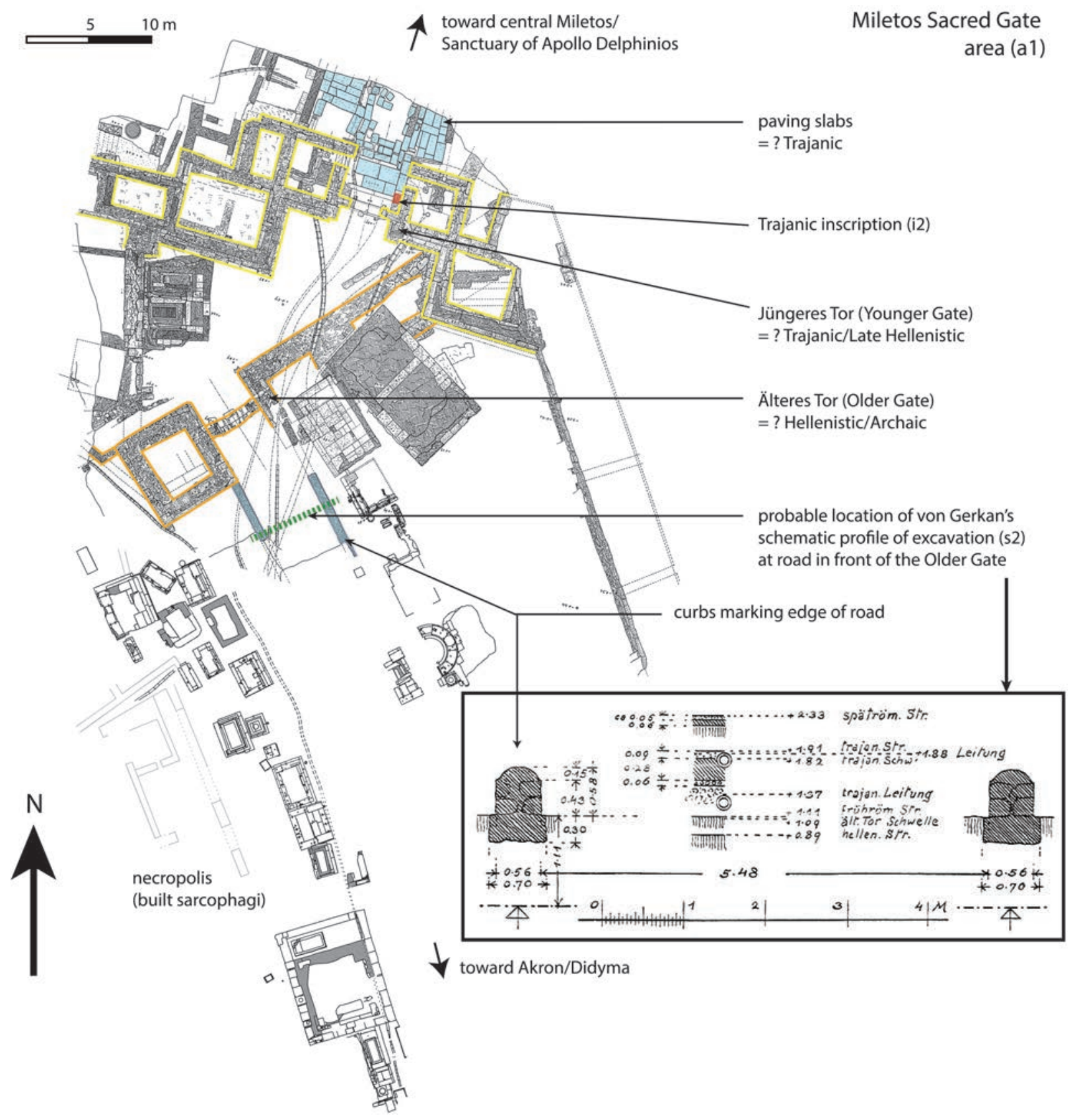

FIG. 6. Plan of the Sacred Gate area at Miletos, showing the buildings, indications of paving inside the Younger Gate, and the probable location of von Gerkan's sondage (marked in green, on outer side of Older Sacred Gate) (modified from Forbeck 1998, plan 3). Inset shows von Gerkan's sketch of strata in the road leading out of the Older Sacred Gate (von Gerkan 1935, fig. 12).

it, however. Walking the area today, it is quite difficult to follow the line he drew since the track edges are not clearly defined. ${ }^{84}$ Fortunately two sets of soundings

\footnotetext{
${ }^{84}$ Together with a group of colleagues, we attempted to retrace Wilski's track in September 2016. Photographs of the land-
}

were later cut into the track as part of the excavation at the Archaic Cult Complex (in 1985) and at the Sanctuary of the Nymphs (in 1990).

scape along the path are to be found on the Project Panormos website at www.projectpanormos.com/sacredway/. 
Next to the Archaic Cult Complex, dated to the second half of the sixth century B.C.E. (see table 4, no. a4; online appx. 1, table 4, no. a4; fig. 3), a sondage measuring approximately $8 \times 4 \mathrm{~m}$ was dug in 1985 (see table 3, no. s7; online appx. 1, table 3, no. s7; fig. 7). The trench designated "TEM1" was laid across both the track and a terrace or boundary wall, on which an archaic sphinx sculpture had been found. ${ }^{85}$ The track was excavated down to a surface of cracked and smoothed limestone bedrock, which Tuchelt interpreted as the actual road surface (fig. 8), but there was no evidence of wheel marks or intentional leveling. No datable ceramics could be identified in the overlying fill, ${ }^{86}$ although any finds found above the rock surface could only practically have provided a terminus ante quem. ${ }^{87}$ The wall (the road's upper terrace wall, or Stützmauer) on the uphill (northwestern) side of the track supports a shallow terrace between the track and the complex above. This wall was paralleled on the downhill side at a couple of locations outside the areas of excavation by short lines of stones (the lower terrace, or Bruchsteinmauer). Assuming these do indeed represent curbstones, the distance between the two would suggest a road width of approximately 5.3-6.3 m. ${ }^{88}$ Tuchelt argued that parts of the upper Stützmauer included reused stone material from the Archaic-era building and therefore formed part of a later phase of (re)construction. He associated this explicitly with the repairs referred to in the Hellenistic building inscription already discussed (i3). ${ }^{89}$

At the Sanctuary of the Nymphs (see table 4, no. a5; online appx. 1, table 4, no. a5; fig. 3), in 1994, an area of approximately $2 \times 6 \mathrm{~m}$ was excavated southeast and downhill of another upper terrace Stützmauer supported by stone blocks (see table 3, no. s9; online appx. 1, table 3, no. s9; marked as sondage "SS 94/18" on fig. 9 plan). Another $3 \times 4 \mathrm{~m}$ sounding was excavated on the uphill (northwest) side of this same terrace (see table 3, no. s10; online appx. 1, table 3, no. s10; sondage "SS 94/07").90 The terrace wall itself was not excavated

\footnotetext{
${ }^{85}$ Tuchelt et al. 1996, 4-5, 118, pl. 7.1-4; cf. Tuchelt et al. 1989, 152-53. Note that the final report (Tuchelt et al. 1996) adopted a new numbering system from that used in the earlier reports. E.g., "sondage/SON 2" in Tuchelt et al. 1989 became "TEM1."

${ }^{86}$ Tuchelt et al. 1996, 203 (grid square N14).

${ }^{87}$ The age of the rock itself provides the only terminus post quem.

${ }^{88}$ Tuchelt et al. 1996, 5 .

${ }^{89}$ Tuchelt et al. 1989, 191-94; 1996, 5.

${ }^{90}$ Bumke et al. 2000, 90-1, figs. 3, 28.
}

fully. ${ }^{91}$ The fill on the downhill side revealed no stratified surfaces, only very shallow layers (marked 7, 8, and 9 on fig. 9, top left) with mixed Archaic, Hellenistic, and Byzantine ceramic fragments. As at the Archaic Cult Complex, the fill covered smooth limestone bedrock, likewise interpreted as the road surface (see fig. 9, top right). Erosion has made the lower (southeastern edge) of the road difficult to define. Schneider's earlier sketch of the same area showed two parallel walls, with a road approximately $5 \mathrm{~m}$ wide between them, but it seems the lower Bruchsteinmauer was not confirmed by the later investigations. ${ }^{92}$

The trenches at both the Archaic Cult Complex and the Sanctuary of the Nymphs offer limited evidence to allow a secure dating of the track that Wilski mapped. In the case of the Archaic Cult Complex, the possible reuse of Archaic-era blocks in the construction of the upper terrace wall suggests a post-Archaic construction for these side structures, although the track itself could be older. In neither location was the terrace wall excavated completely to reveal the foundations that might offer more secure dating and construction clues. The mixed finds found in the fill below the upper terrace wall at the Sanctuary of the Nymphs demonstrate only that the limestone surface could have been exposed right up to the Byzantine era.

\section{From Akron to Panormos: Explaining the Uncertain Course Around Mavişehir}

A little way south of the Sanctuary of the Nymphs, the valley currently known as Mersinli Dere Vadisi becomes wider and flatter. From here southward, as the road leaves the Akron, any continuation of Wilski's Antike Strasse becomes difficult if not impossible to identify. Schneider projected the reconstructed course of the road downhill, pointing to lines of stones that he took to be remaining fragments of curbstones (i.e., the continuation of the framing Stützmauern). But, at a certain point, he could not identify even such tentative traces of road. ${ }^{93}$ Schneider's reconstruction for this

\footnotetext{
${ }^{91}$ The excavators argued on the basis of a coin find (Bumke et al. 2000,91, no. 132) that the Stützmauer should date before the fourth or third century B.C.E., but the sondage did not actually reach the base of the wall itself.

${ }^{92}$ Schneider 1987, 111-12, fig. 8; cf. Bumke et al. 2000, fig. 6.

${ }^{93}$ The cobbled road with boundary blocks, which skirts at least part of this reconstructed route, actually connects the Panormos harbor to inland farmsteads southeast of the Akron Hills; it seems to be an Ottoman construction, based on the Ottoman sites, including cemeteries and a cistern (including Palamut Mezarlığı, Ustamehmet Sarnıcı, Arap Mezarlığı) along its path.
} 


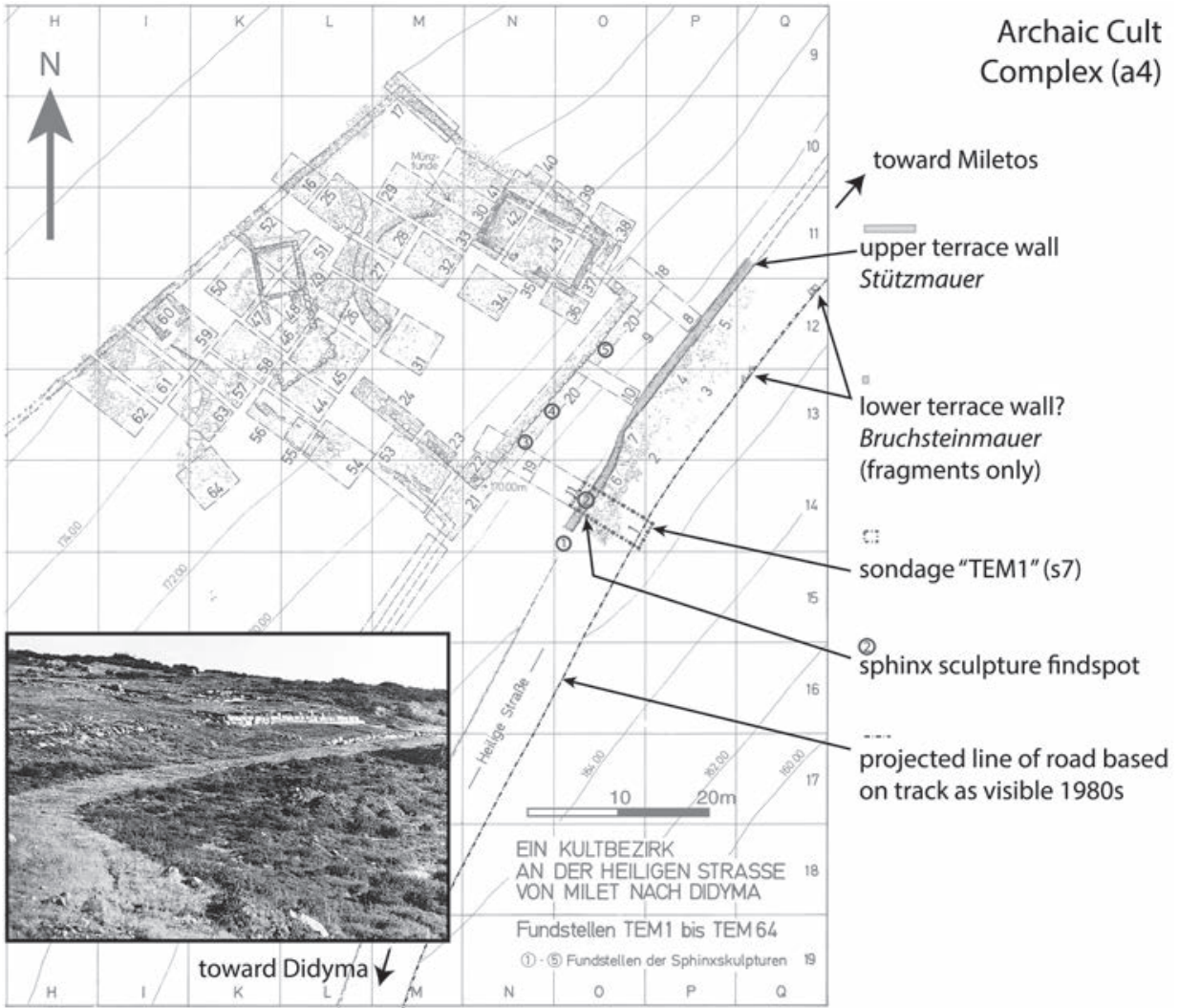

FIG. 7. The Archaic Cult Complex in the Akron Hills. Plan shows the location of sondages, including TEM1, across the road (after Tuchelt 1989, fig. 90). Inset shows the site from the south (Tuchelt et al. 1996, pl. 6.3).

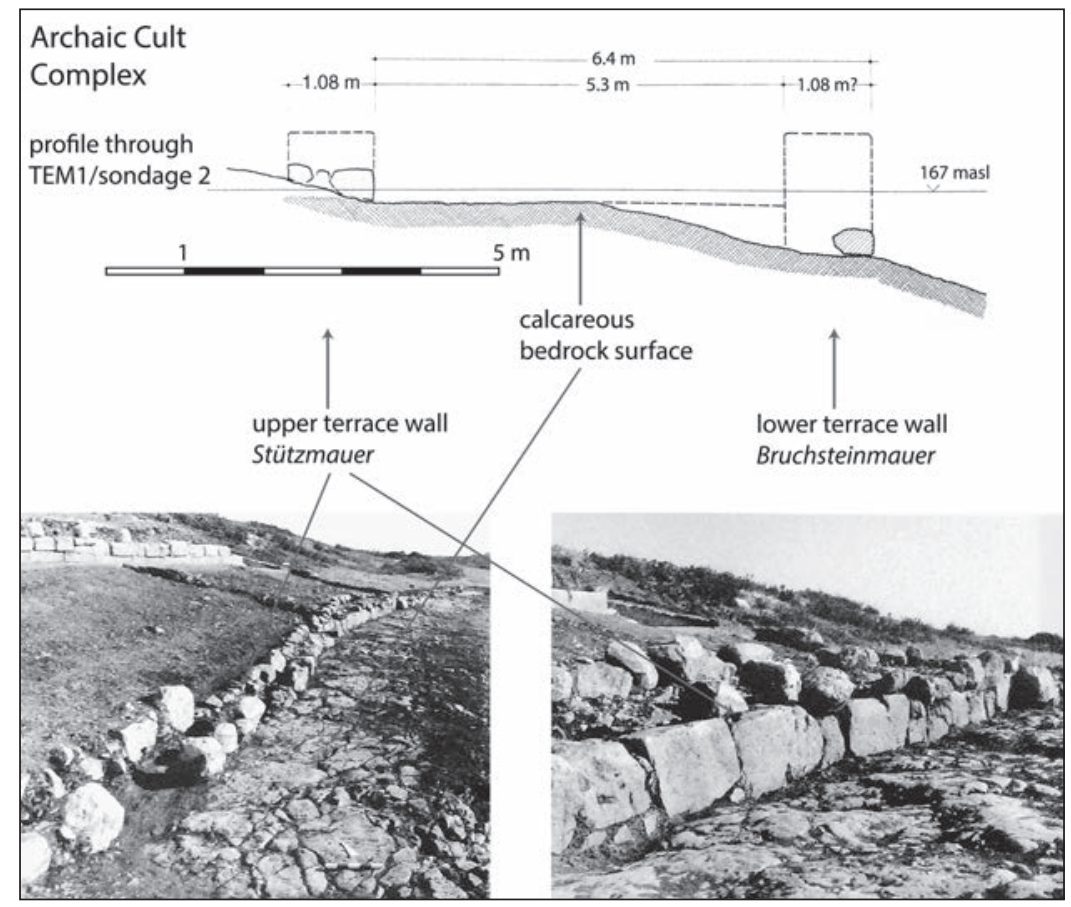

FIG. 8. Excavation TEM1 at the Archaic Cult Complex: top, section across the road (after Tuchelt et al. 1996, fig. 2); bottom, excavated area, from south (Tuchelt et al. 1996, pls. 7.1, 7.2). 


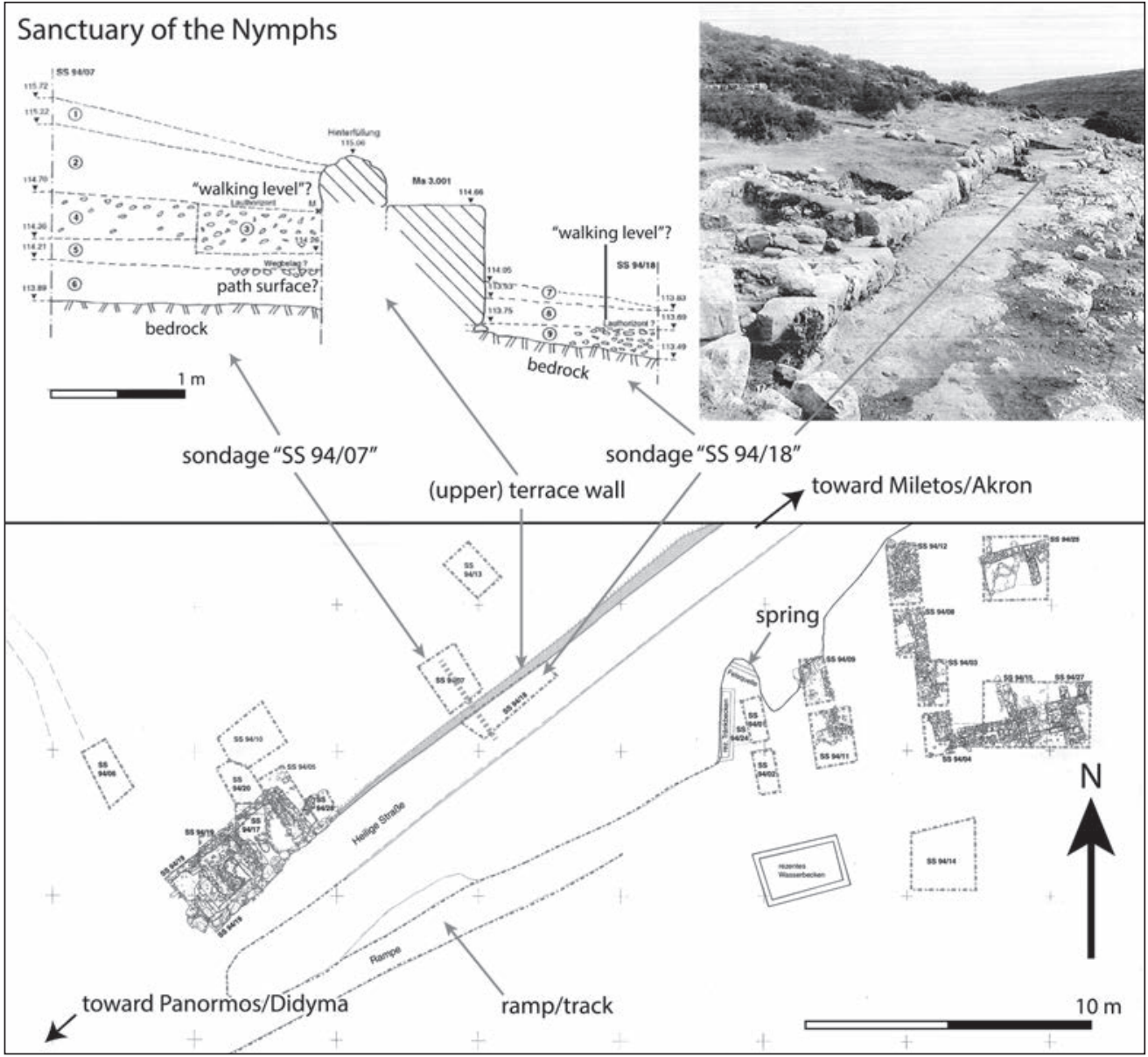

FIG. 9. The Sanctuary of the Nymphs (or Quellbezirk): top left, section through sondage SS94/18 (after Bumke et al. 2000, fig. 28); top right, photograph of sondage SS94/18 across the road (in center), terrace wall (at left of road), and sondage SS94/07 (to the left of the wall) (Bumke et al. 2000, fig. 3); bottom, plan showing location of sondages undertaken, including across the road (after Bumke et al. 2000, insert map).

segment around Panormos (modern Mavișehir), based on topographically informed speculation, skirts around the two ridges separating the valleys of Mersinli (To Stena Bogasi on Wilski’s map), Çınarlı (Ta Platania/ Tu Kolia to Bogasi), and Sulubatak (Ta Klimata) before ascending again along the eastern side of an unnamed narrow valley southeast toward Didyma, ${ }^{94}$ following a route similar to that of the modern road to the temple. Despite a program of test trenches placed along parts of this projected route, undertaken by the Milet Museum in 2010-2011 (see table 3, no. s12; online appx. 1, table

\footnotetext{
${ }^{94}$ This valley is not named on any map we have seen, but it lies between the low hills of Işıı Tepe and Yassıtepe on the modern Turkish national maps, and west of Tu Kodscha to Bagtscheh on Wilski's map.
}

3 , no. s12), ${ }^{95}$ unequivocal remains of ancient roadway in this key part of the assumed route have proven elusive.

As is the case for the undetermined segment around Akköy, there are several plausible hypotheses for the absence of road traces, which are not mutually exclusive. The first is that, aside from the few hundred meters beyond the gates of Didyma and Miletos, which have paving and curbstones, and the track through the Akron, which because of the unstable slope required built terracing, the Sacred Way may have been little more than a dirt track for most of its route. Identification of such a track would be almost impossible. The second

\footnotetext{
${ }^{95}$ These have not been published, but the Milet Museum report archive contains the documentation on where this series of trenches were dug.
} 
is that the landscapes around Akköy and Panormos/ Mavişehir have experienced substantial agricultural activity in the modern era, and this activity may have destroyed the evidence. The third hypothesis, of most relevance to Panormos, is that various geomorphological processes have contributed to an accumulation of alluvial or colluvial soils that has masked the evidence.

Indications for the dynamic geomorphological history of this subregion of the Milesian Peninsula may offer potential support for this third hypothesis. The recent excavations we undertook at a necropolis at $\mathrm{Pa}$ normos (see table 4, no. a6; online appx. 1, table 4, no. a6), located on the east side of the narrow unnamed valley just mentioned, have revealed a considerable degree of sedimentation. For example, the mortuary deposits seen in sondage $S 1$ (fig. 10, top) were covered by up to $2 \mathrm{~m}$ of post-Archaic fill (see table 3, no. s13; online appx. 1, table 3 , no. s13). ${ }^{96}$ Similar or even more dramatic levels of accumulation could easily be imagined for the larger flat valleys just to the north (e.g., in Çınarlı or Sulubatak) (see fig. 10, bottom).

Additionally, the topographic and geomorphological situation also suggests the possibility that the narrow coast strip and parts of the flat valleys near Panormos were covered by the sea in the past; in that case, the coastline of any harbor would have been situated at least half a kilometer to the east in antiquity. ${ }^{97}$ Recent activity in the area has demonstrably moved the coastline westward. Large stone blocks (see table 4, no. a7; online appx. 1, table 4, no. a7), recorded on Wilski’s 1906 map as a possible ancient dock (Landungssteg), were never fully investigated or dated even though they were apparently visible into the 1970 s. ${ }^{98}$ Today this area of sea is covered by reclaimed land and the modern concrete iskele (pier). Coastline shift in this area has serious consequences for the reconstruction of the Sacred Way: if substantial parts of this area were underwater or were wet salt marshes, it makes it less likely a road would be sited here.

The problem is providing a chronology for this process of accumulation, which cannot be resolved until coring of the sediments in these valleys is undertaken.

\footnotetext{
${ }^{96}$ Slawisch 2014,116 . The excavations at this necropolis were undertaken over three seasons, 2012-2014. The final publication is in preparation.

${ }^{97}$ For the first suggestion of a difference in the coastline around Panormos in antiquity, see Wiegand 1929, 11.

${ }^{98} \mathrm{~A}$ photograph from the DAI Didymaarchiv in Berlin (no. 72/143) from 1972, before the land was reclaimed, shows large blocks assumed to be the ancient pier.
}

A preliminary impression can be obtained by examining the distribution of surface finds established by a recent intensive survey pilot we started in 2015. The entrance to the Sulubatak Valley (marked on fig. 11) is characterized by very low densities of ceramics, suggesting substantial accumulation of sediment, perhaps recent. Slightly inland, in an area of the valley known as Subatağ 1 Mevkii (see fig. 11; cf. fig. 10, bottom), ${ }^{99}$ a cluster of ceramic finds were predominantly of Roman date (perhaps the remains of a farmstead), with very few older finds (see table 4, no. a8; online appx. 1, table 4, no. a8). The pattern of distribution contrasts starkly with much of the rest of the surveyed area, in which sherds dating to the Archaic period are almost ubiquitous. There are two plausible interpretations of this surface distribution of pottery in the Sulubatak/ Subatağ 1 Mevkii area. One is that the area was essentially uninhabitable before the Roman era, and hence the cluster here represents a new Roman foundation. The other is that older (i.e., Archaic-era) remains are deeply masked by sedimentation during or before the Roman era. This seems less probable, however, unless we assume that there was also a lower sea level in the pre-Roman era than today. In either case, we must assume that there was a substantial degree of sediment accumulation and landscape transformation during, or more likely before, the Roman era.

\section{From Panormos to Didyma: The Branchidae and the Straßentor}

Two kilometers southeast and uphill from Panormos, the slope leading up to the Temple of Apollo has been subject to numerous excavations since Gell first described the track here as a sacred way in 1812 , on the basis of the line of Branchidae monuments (see table 4, no. a11; online appx. 1, table 4, no. a11). Unfortunately, most of these excavations were either unsystematic (as is the case for the earliest works) or have been published only cursorily, if at all. ${ }^{100}$ Knackfuß provided perhaps the first systematic diagram of the relationship of this track to the temple, tracing a line of approximately $300 \mathrm{~m}$ on the basis of visible curbstones and

\footnotetext{
${ }^{99}$ The modern place-names, with Turkish "su-" (water) and "sulu-" (watery), hint at this area's continued wateriness into recent times.

100 The latest sondages, undertaken by Tuchelt's team in 1987, still remain unpublished (see table 3, no. s8, online appx. 1 , table 3, no. s8). References to their results here are based on the excavation notebooks from the DAI Didymaarchiv in Berlin (Tuchelt 1985-1986, 1986-1987).
} 

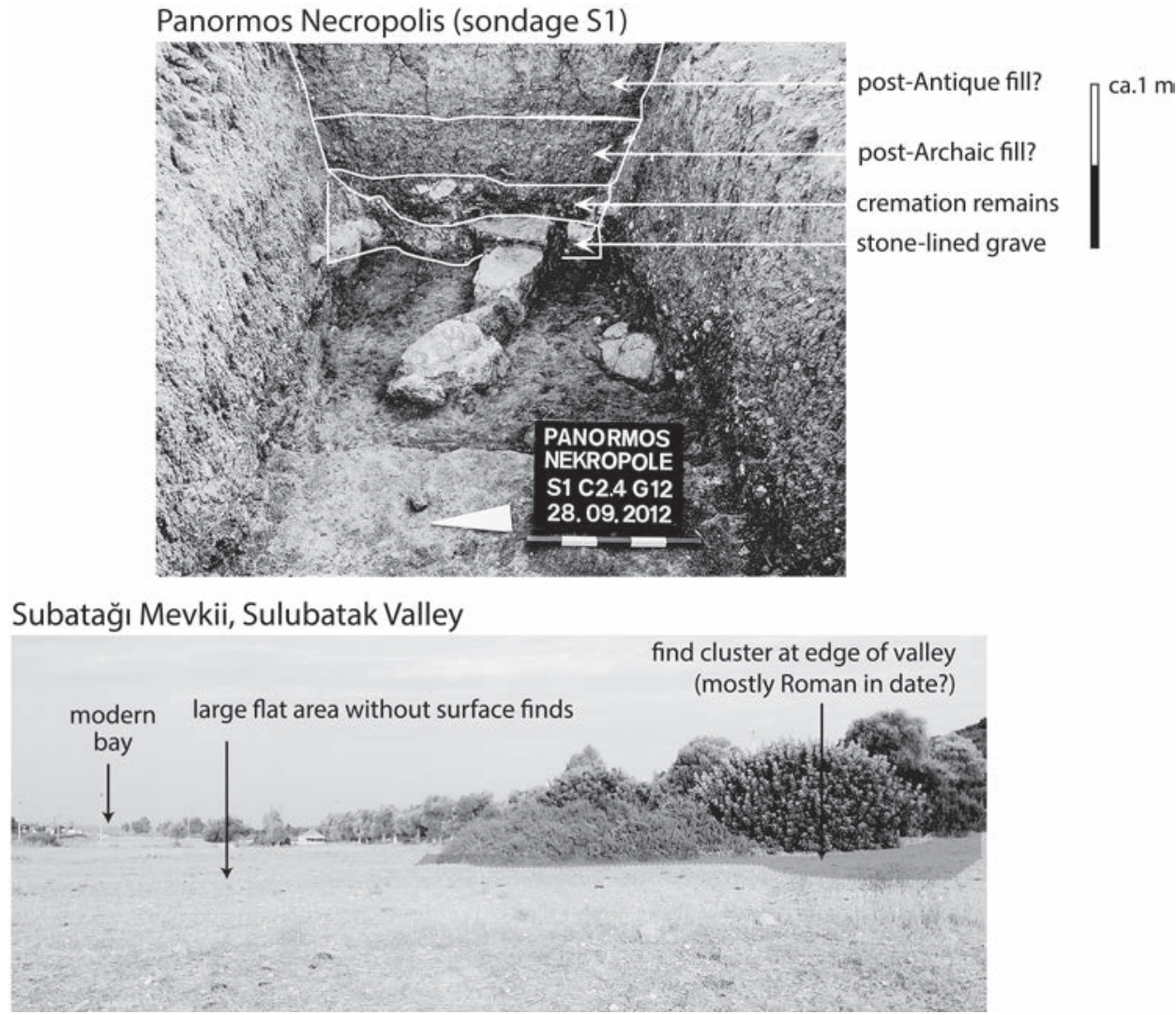

FIG. 10. Panormos region: top, approximately $2 \mathrm{~m}$ of post-Archaic sedimentation as seen in sondage S1 at the Panormos Necropolis (C) Project Panormos); bottom, Sulubatak Valley topography and area with dense cluster of Roman pottery identified during 2015 survey (C Project Panormos).

the series of early trenches (from 1906 and 1938). ${ }^{101}$ Schneider illustrated this same path as part of his reconstruction (the basis for fig. 12), including the distribution of several disturbed Roman sarcophagi (see table 4, no. a10; online appx. 1, table 4, no. a10; fig. 13, top), the assumed location of the Branchidae statues before Newton removed them, and a detailed plan of the Straßentor (see table 4, no. a12; online appx. 1, table 4, no. a12; fig. 13, bottom).

Of the slightly better documented sondages undertaken in this segment (see table 3 , nos. s2, s3, s8; online appx. 1, table 3, nos. s2, s3, s8), including Tuchelt's post-1986 unpublished excavations, it is notable that no street levels were identified that could be dated earlier than the Hellenistic period. ${ }^{102}$ Pottery and tile finds

${ }^{101}$ Knackfuß 1941, 157, fig. 3.

${ }^{102}$ The zone being discussed is today bounded on the west by a gas station (beyond which no road has been identified) and on the east by the paved segment of road discussed further below. Knackfuß identified the locations of excavations carried out in of Archaic date certainly indicate that the area was used during this period and may even indicate the presence of buildings or terraces, but no unequivocal evidence for the roads or tracks that presumably served them was found. In the context of surface distributions from the recent survey already discussed around Panormos, which documented archaic finds throughout the region (see fig. 11), the archaic finds in these sondages may not be all that surprising.

The major monuments of this segment, the Roman sarcophagi, the Branchidae, and the Straßentor, also present serious interpretative challenges with regard to their dating and meaning. None of these monuments can be used as persuasive evidence for the existence of an Archaic-period street. Foundations of the structure frequently termed the Straßentor (Street Gate; see table 4, no. a12; online appx. 1, table 4, no. a12; figs. 3;

this zone in 1906-1907. For his comments on these early excavations, see Knackfuß 1941, 156-58, fig. 3. For additional sondages from 1986 and 1987, see Tuchelt 1985-1986, 1986-1987. 


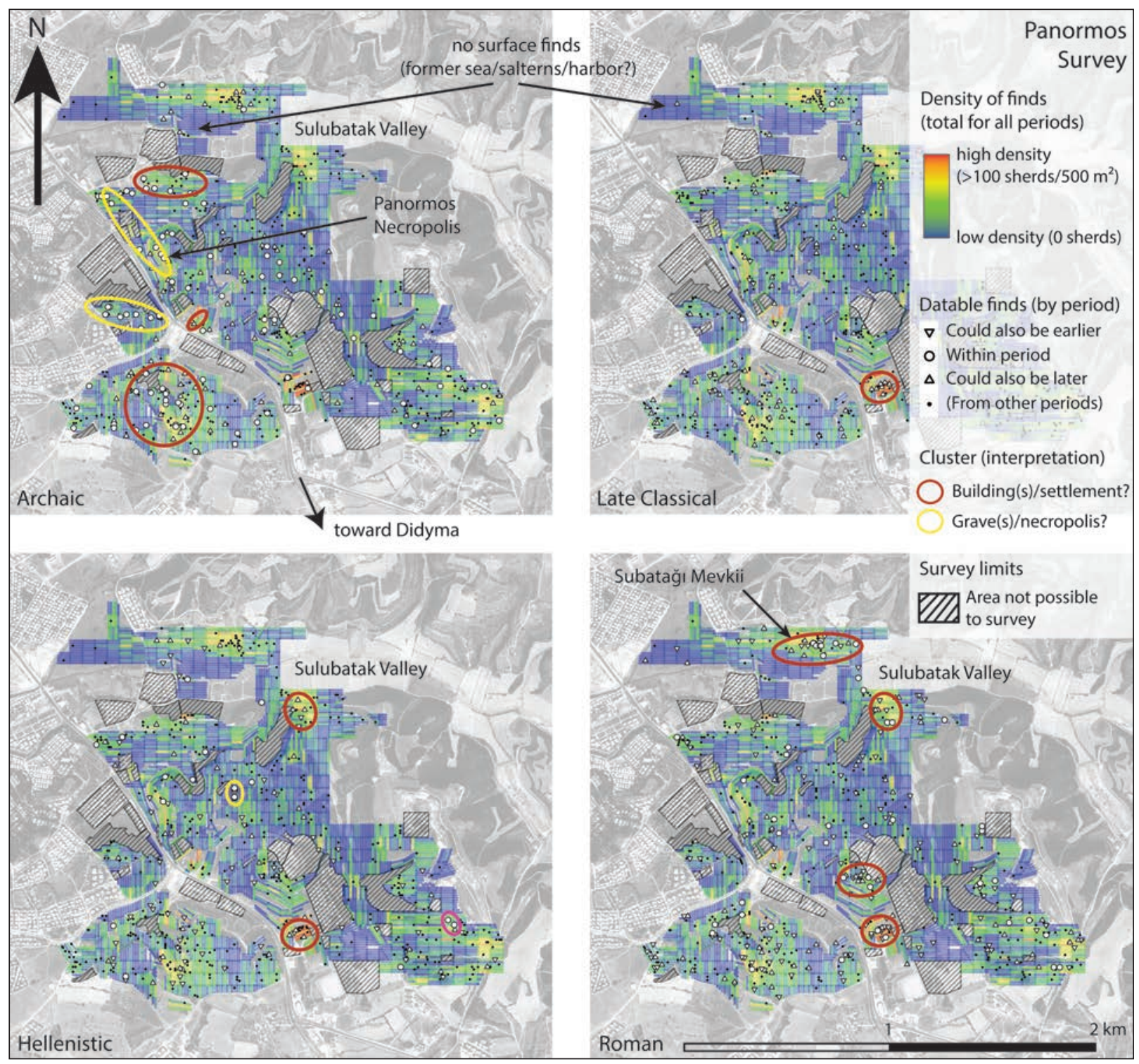

FIG. 11. Panormos intensive survey 2015 results, maps showing distribution of surface pottery finds by period, with major clusters highlighted (drawing by N. Strupler; @ Project Panormos).

12 ; 13 , bottom), which lie near the line of the street, were identified in 1907 and subsequently reexamined in 1979 and 1987 (see table 3, no. s8; online appx. 1, table 3, no. s8; trenches SS 87/F, SS 87/M). Knackfuß proposed that this structure could have been some kind of arched street gate and therefore could have marked the boundary to the sanctuary at Didyma, ${ }^{103}$

\footnotetext{
${ }^{103}$ Reports of the investigations undertaken ca. 1907 (Wiegand 1911, 37; cf. Knackfuß 1941, 156-57) describe small foundations of rubble masonry with mortar at a distance of $350-360 \mathrm{~m}$ from the temple, on both sides of the road. Knack-
}

an interpretation that has proven evocative and popular. ${ }^{104} \mathrm{He}$ also considered another possibility, that the blocks instead provided a base for votive statues; this

fuß assumed this structure to be a simple gate, perhaps with marble orthostats. No original documentation or photographs have survived (a fire at the excavation house destroyed both papers and finds ca. 1922), and no architectural fragments have subsequently been linked with this putative structure; cf. Tuchelt 1973, 17. Works conducted in 1979 revealed only one foundation to the north of the street (Tuchelt 1980; see also fig. 13, bottom).

${ }^{104}$ Herda 2006, 257 n. 1827. 


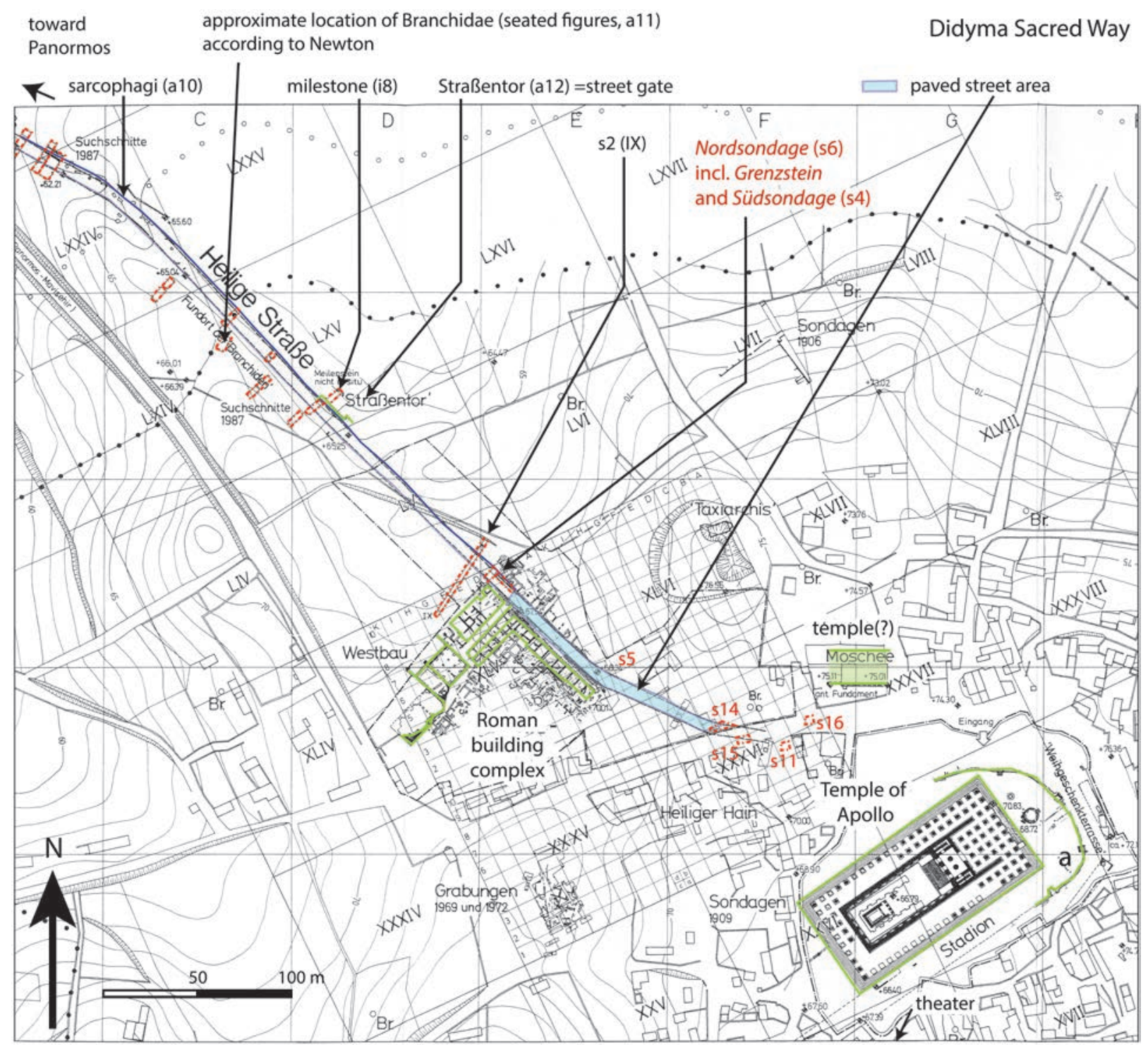

FIG. 12. Plan of Didyma and the area to its northwest, showing the findspots of the Branchidae statues, the locations of the Straßentor, and the paved section of the Sacred Way (modified from Tuchelt 1989, fig. 89).

uncertainty is reflected in the more neutral label for the structure (Fundament) found on some plans. A statue base is at least equally plausible, given that no foundations south of the road (which would be needed if this were a gate or an arch) have been confirmed (see fig. 13, bottom). Dating the structure and understanding its relationship to the road have proven difficult. ${ }^{105}$

\footnotetext{
${ }^{105}$ When the structure has been interpreted as a Straßentor, the assumption has often been that the gate was part of a monumental Hellenistic or Roman boundary to the sanctuary. Recently, Herda (2006, 373 n. 2640) has cited Tuchelt's personal
}

Dating, location, and interpretative problems also beset the Branchidae statues (see table 4, no. a11; online appx. 1, table 4, no. a11). These seated figures, first described by Gell, were excavated and exported by Charles Newton between 1857 and $1858 .^{106}$ The precise orientation and find locations of each of these

comments, based on the unpublished 1987 soundings, that these foundations were Archaic in date. We find this difficult to confirm given the lack of contextual explanation as to how this date is assigned.

${ }^{106}$ Tuchelt 1970, 27-33. 


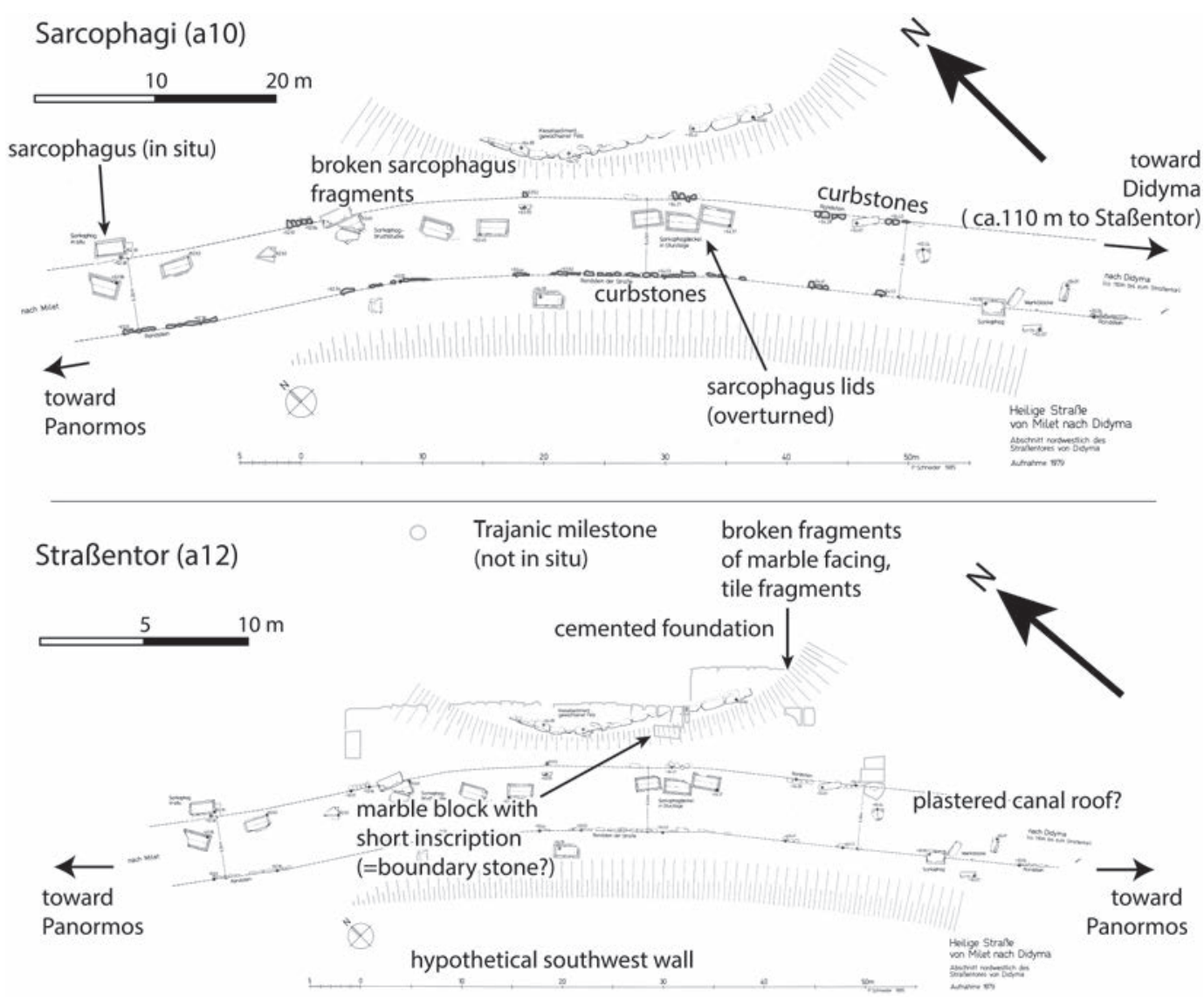

FIG. 13. Monuments along the Sacred Way near Didyma: top, plan showing details of stone sarcophagi located on the Sacred Way near Didyma (after Schneider 1987, fig. 19); bottom, detailed plan showing the foundations of the structure conventionally termed the Straßentor (Street Gate) (after Schneider 1987, fig. 24).

figures were, unfortunately, not mapped, but Newton noted approximate distances and drew sketches of the statues in situ, so it is generally assumed that they were removed from an area just northwest of the Straßentor structure on the south side of the road. ${ }^{107}$ Stylistically, the general date of initial manufacture for these seated figures is agreed to be Archaic (i.e., sixth century B.C.E.), although differences of $+/-20$ years are given to individual figures by different scholars. ${ }^{108}$ Slight variations in size and stylistic details, understood as indications of chronology, have been taken to suggest that the group was formed by the addition of a statue every $10-20$ years or so during the course of the sixth

\footnotetext{
${ }^{107}$ Newton's distances were usefully summarized in Schneider 1987.

108 Tuchelt 1970, 79-80 (570/60 B.C.E.); Herda 2006, 115-338.
}

century ${ }^{109}$ The figures were almost certainly on display as part of the configuration of the sanctuary at Didyma during sixth century B.C.E.

The term Newton gave to this group of statues (i.e., the Branchidae) is itself a problematic one. Most commonly the word appears as an alternative place-name for Didyma in ancient sources, ${ }^{110}$ although inscriptions with this place-name have never been identified. The literary references have been interpreted as implying

\footnotetext{
${ }^{109}$ Confidence in this level of chronological resolution is perhaps overly optimistic for stylistic dating, since the variations might also reflect different styles from different workshops, or emulation of older styles from different media. The absence of heads for most of the statues also makes the dating of the figures difficult, as the style of faces and hair is usually taken as a finer indicator of chronology.

${ }^{110}$ Hdt. 1.46, 1.92, 1.157, 1.159, 5.36; Paus. 9.10.2, 8.46.2, 2.10.4.
} 
that the term also referred to the priestly order of hereditary seers who ran the oracular sanctuary. ${ }^{111}$ The priests, therefore, are candidates for the identities of the seated figures despite their controversial reputation of collaboration with the Persians. ${ }^{112}$ Given that only one of the statues has any identifying inscription, this connection is speculative, and they are usually assumed to represent local leaders, landowners, or priests. ${ }^{113}$ The four nearly complete statues that were removed by Newton (and are now in the British Museum) are the ones usually known as the Branchidae. But, in total, a minimum of 23 similar seated figures of widely varying degrees of preservation, apparently all of sixth-century date, have been identified around Didyma ( 7 female, 13 male, and 3 too incomplete to tell). A further 14 (all female) were found at Miletos; fragments from 24 (14 male, 10 female) were found at the Archaic Cult Complex; ${ }^{114}$ and one (without the head) was found next to the spring at the Sanctuary of the Nymphs. ${ }^{115}$

The largest statue removed by Newton bears the

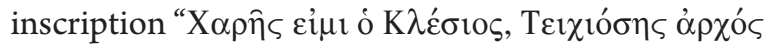

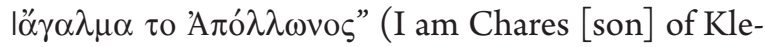
sis, archos of Teichiosa, gift to Apollo). The text is arranged vertically along the corner of the front, right leg of the stool on which the figure sits. ${ }^{116}$ The other seated figures in Newton's group had no discernable inscriptions, but a few of the seated figures found at other locations (including the one at the Sanctuary of the Nymphs) were inscribed with names: the artist, the sponsor, or the god(s) to whom the statue(s) were dedicated. ${ }^{117}$ As mentioned above, one of the stations listed in the Molpoi inscription is the "statues of Chares," which suggests these figures formed an integral part of the Hellenistic Molpoi procession along the

\footnotetext{
${ }^{111}$ Hdt. 1.46; cf. Furtwängler 2014, 248.

${ }^{112}$ The priests of the fifth century were accused by one of Alexander's propagandists of enabling the shipment of treasure from Didyma to Darius and then following him to Sogdiana in central Asia (Kallisthenes in FGrHist 123F 14; Strabo 7.1.43). See Ehrhardt $(1998,15)$ for doubts about the historicity of this story of betrayal.

${ }^{113}$ Tuchelt 1970, 194, 216.

${ }^{114}$ Tuchelt 1970, 71-94, 144.

${ }^{115}$ Supra nn. 22, 51; Tuchelt 1970, 217.

${ }^{116}$ Tuchelt 1970, 78-80 “K47”; Herda 2006, 334-50.

${ }^{117}$ Tuchelt $(1970,215)$ also notes that one of the inscriptions mentions the dedication of a group of statues of which at least one was a seated figure; he also emphasizes that we do not know whether this seated figure was supposed to represent the sponsor, Ermesianax.
}

"wide road." 118 If the Molpoi text does represent a full or even partial relic from the Archaic period, then it is easy to infer that the statues played a similar role in an Archaic-era processional route. Herda, for example, takes this connection as evidence to support his arguments for ritual and spatial continuity in cult practice from the Archaic through the Classical to the Hellenistic era, envisaging the kernel of the original composition of the Molpoi text as dating ca. 555-520 B.C.E., one generation (20-30 years) after the manufacture of the statue with Chares' inscription. ${ }^{119}$

Most problematic is the fact that none of the Branchidae statues was found with a base or foundation. ${ }^{120}$ This means that the location in which they were found in the 19th century is unlikely to have been their original one. We have little idea where that original location might have been or when their removal or rearrangement took place.

The fact that the Chares statue was a "gift to Apollo" suggests that, when installed, it stood within the temenos of Apollo, presumably with other seated figures. The boundaries of this temenos are unfortunately uncertain and may well have changed through time. The delimitation of this zone must have been complicated, as now seems likely, by the close proximity of temples to gods other than Apollo in the Didyma precincts. The foundations of the Straßentor (see table 4, no. a12; online appx. 1, table 4, no. a12) or the more easterly horos stone, or Grenzstein (discussed below; see table 4, no. a13; online appx. 1, table 4, no. a13; cf. table 3, no. s6; online appx. 1, table 3, no. s6; found in the Nordsondage, marked on fig. 12), may well have marked the boundary of the sanctuary in the Hellenistic and Archaic periods, respectively. If so, the 19th-century location of the Branchidae figures would represent either a potentially iconoclastic removal to a place outside the sacred area or perhaps more plausibly the expansion of the temenos at a later point. One inscription records that the asylum of the temple was in fact expanded during the reign of Julius Caesar, ca. 50 B.C.E., with the northwest boundary perhaps extending almost as

\footnotetext{
${ }^{118}$ The use of the plural "statues" in the Molpoi inscription does not seem to imply that all the figures represented the same individual "Chares." They may have formed a recognizable group through assumed common sponsorship by Chares or more likely simply by association with the named/labeled figure.

${ }^{119}$ Herda 2006, 343.

${ }^{120}$ Knackfuß 1941, 156.
} 
far as Panormos. ${ }^{121}$ This would mean that by the time of Trajan's project of rebuilding, the area in which the Branchidae were found had already become part of the sacred zone.

If either the Straßentor or the horos/Grenzstein might in fact represent the boundary of the temenos at some point in Didyma's history, the position of the Branchidae statues and their lack of foundations suggests the likelihood that they were moved as part of a major project of refurbishment. Presumably, as gifts to Apollo, their relocation can also only have happened during a period when the temenos was expanded. The two most likely opportunities for such significant change would be (1) during the major renovations and redesign of the new temple in the Late Classical or Hellenistic period-that is, in the 150 years before the Molpoi inscription was put on the stele we have today, when an expanded temple may have required a reconfiguration of the contents of the temenos; or (2) during the second-century C.E. renovations of the Sacred Way undertaken by Trajan, at a time when we know that the temenos was already much bigger. In either scenario, a deliberate attempt to establish the legitimacy of a tradition of a procession, such as that described in the Molpoi inscription, could have been helped by an appropriation of real, if repositioned, archaic monuments such as the Branchidae. The ultimate position of the Branchidae in the 19 th century C.E. thus provides no reliable indicator of the route or even the existence of a clearly defined Sacred Way during the Archaic or Hellenistic era.

\section{Arriving at Didyma: The Paved Street}

The section of roadway most usually associated with the Sacred Way begins only a few hundred meters northwest of the Temple of Apollo at Didyma. Here, the dating of the well-preserved limestone paving stones (see table 4, no. a14; online appx. 1, table 4, no. a14) to the Trajanic era, specifically to $101 / 2$ C.E., is based primarily on inference from the Trajanic building inscriptions (esp. the one from the Sacred Gate at Miletos and its matching documents from Didyma) discussed above, but the pottery excavated here seems

\footnotetext{
${ }^{121}$ Caesar is reported to have enlarged the asylum of the Temple of Apollo by nearly $3 \mathrm{~km}$ in 44 B.C.E. According to Rehm (1958, no. 391 AII), this expansion would have extended the asylum at least as far as the harbor of Panormos; cf. Tuchelt 1973, 24; Fontenrose 1988, 30.
}

to support the Roman date. ${ }^{122}$ This section of paving measures approximately $4.90-5.00 \mathrm{~m}$ wide $^{123}$ and has been preserved for a length of approximately $130 \mathrm{~m}$ (see figs. 12, 14), starting about $200 \mathrm{~m}$ southeast of the Straßentor and continuing to within $100 \mathrm{~m}$ northwest of the temple itself (apparently stopping where the modern road passes through the village). ${ }^{124}$

Two soundings (see table 3, nos. s6, s4; online appx. 1 , table 3, nos. s6, s4) were dug by Tuchelt's team in 1972 and 1983 below the level of the paving, in places where stones had already been robbed, to examine possible earlier developments. They are identified as the (Heilige Strasse) Nordsondage and Südsondage (see fig. 14). On the basis of the two examined stratigraphic sections (fig. 15), ${ }^{125}$ the excavators posited five road phases and number of subhorizons: Heilige Strasse (levels) I (the latest Trajanic level), II (200 B.C.E.100 C.E.), III (250-200 B.C.E.), IV (600 or 400-250 B.C.E.), and V (seventh to sixth century B.C.E.). ${ }^{126}$

To accompany these results, the excavators prepared a set of period-by-period plans that relate these sondages to the other nearby excavated structures (including the area thought in the 1980s to be a sanctuary of Artemis) and offer reconstructions for the size and position of the Sacred Way at each period. ${ }^{127}$ Reexamination of the plans suggests that they overestimate the solidity of the evidence for an archaic or classical road. As can be seen in the description of the layers and the isomorphic diagram of the sections, the lowest strata (IV and V) are ill-defined and cannot unequivocally be described as road surfaces. The matrix was not,

\footnotetext{
${ }^{122}$ The dating is supported by the Eastern Sigillata B found in the immediately underlying strata (Tuchelt 1984, 224, pl. 53; 1987, 78-9; Wintermeyer 2004, 11).

${ }^{123}$ Tuchelt 1984, 220, "Straße I."

${ }^{124}$ Tuchelt 1990, 95: "Der Verlauf der Heiligen Strasse wurde im Nordwesten auf 75 m Länge mit den Horizonten der trajanischen, hellenistischen und archaischen Strasse festgestellt. ... Heilige Straße nun auf über 200m Länge erschlossen" (The course of the Sacred Way was determined in the northwest for a length of $75 \mathrm{~m}$ with the horizons of the Trajan, Hellenistic and Archaic streets. .. Sacred Way now uncovered to over $200 \mathrm{~m}$ length).

${ }^{125}$ Cf. Tuchelt 1984, 214-25.

${ }^{126}$ The overlapping nature of the earliest levels (IV and V) reflects the uncertainty of their dating.

${ }^{127}$ Tuchelt 1984, 235-40, figs. 7-12. Note also the slightly modified versions in Tuchelt 1991, 26-31, figs. 42-5, 49; the earliest level, the seventh-century Heilige Strasse V, has been quietly removed, but the speculative sixth or fourth-century Heilige Strasse IV track is still shown.
} 


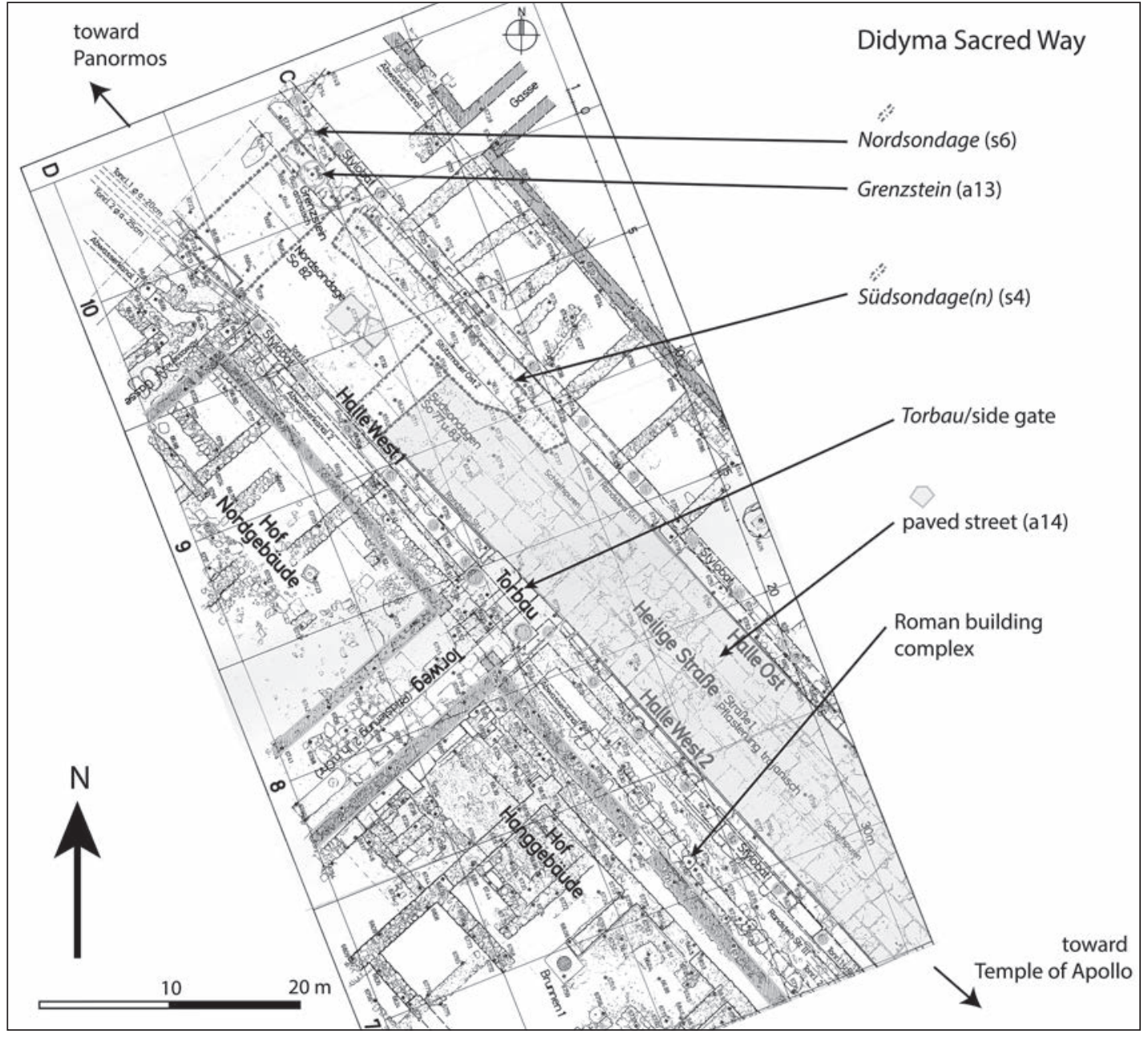

FIG. 14. Plan of the paved street (Sacred Way) at Didyma, showing the locations of Nordsondage and Südsondage, excavated in 1983 (modified from Tuchelt 1984, insert diagram 2).

as Tuchelt acknowledges, paved or graveled, ${ }^{128}$ even though a compressed layer could indeed be a result of traffic (i.e., as a track or road). Both sondages were very restricted in size, and the bedrock was reached only in a very small part of the Nordsondage. If the archaic strata were indeed a road, these sondages do not provide evidence for the shape or direction of the path. ${ }^{129}$ Schneider's suggestive diagrams of the route of the Sacred Way during the Archaic (V) and the Late Archaic and Classical or Early Hellenistic (IV) periods are therefore an exercise in the assumption of route inertia. Unfortunately, the published finds on which the dating of the lowest strata (IV and V) are based do not provide the unproblematic sequence of chronological clues one might hope for and certainly do not offer credible proof of a pre-Hellenistic road.

Tuchelt originally dated the layers of Heilige Strasse IV to between the sixth and fourth centuries, assuming mostly Late Archaic or Late Classical and Early Hellenistic usage. In a later publication of the pottery assemblages from these excavations, Wintermeyer instead assigns these layers to the fourth to third centuries B.C.E. (i.e., Late Classical to Early Hellenistic). ${ }^{130}$ The catalogued finds are, however, not diagnostic from a dating perspective. Wintermeyer refers to some body fragments of kantharoi dating to the second half of the

\footnotetext{
${ }^{130}$ Wintermeyer 2004, 31-3.
}

\footnotetext{
${ }^{128}$ Tuchelt 1984, 221 (Straße IV and V).

${ }^{129}$ As shown in Tuchelt 1984, figs. 7, 8.
} 


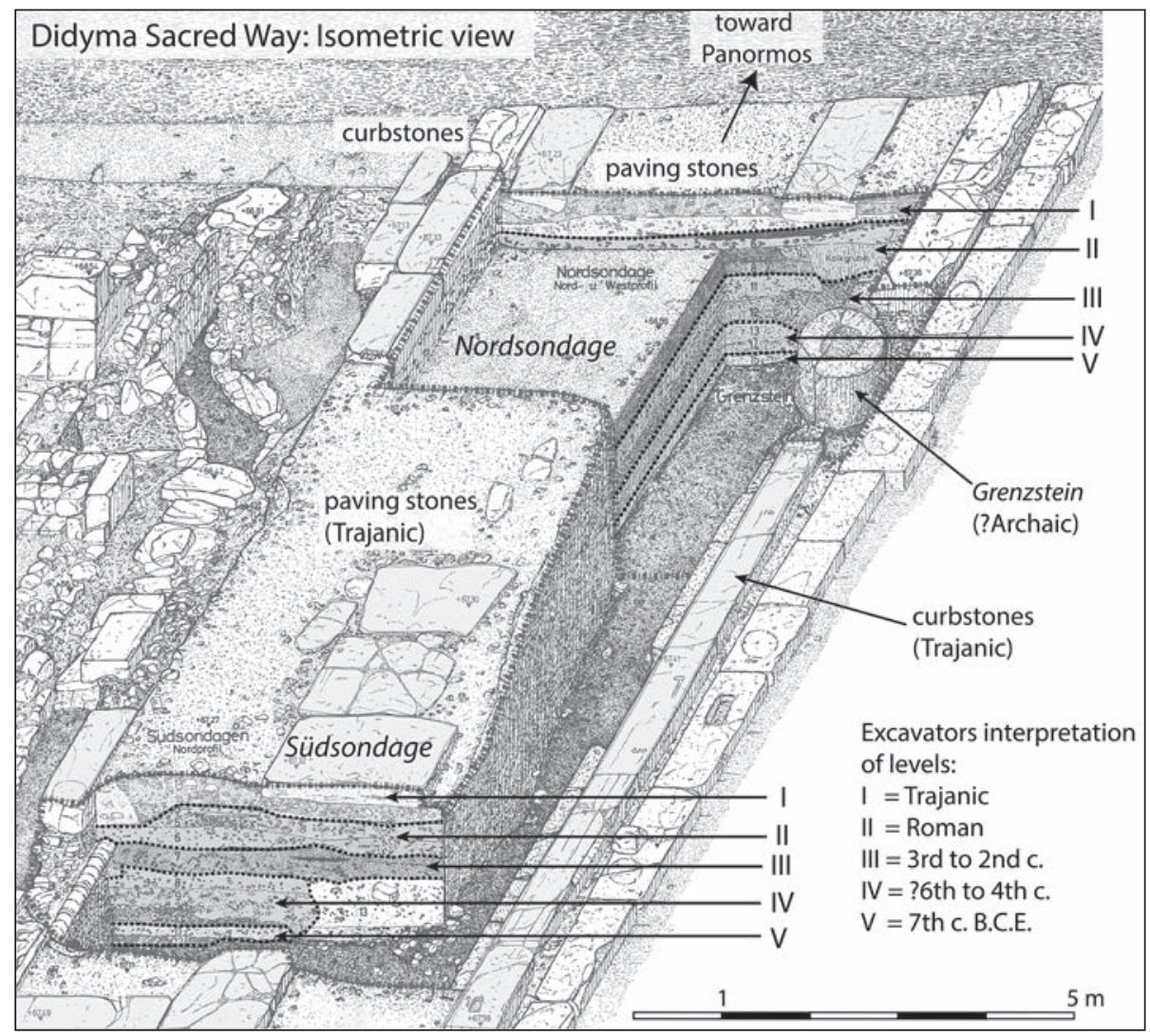

FIG. 15. Isometric diagram of the paved street at Didyma, showing stratigraphy of Nordsondage and Südsondage at the street (modified from Tuchelt 1984, insert diagram 3).

fourth century B.C.E. ${ }^{131}$ and to three coins of differing dates found in the same level: one dated to the late fifth or early fourth century B.C.E., one dating more vaguely to the fourth or second century B.C.E., and one to ca. 250-200 B.C.E. On these anchors alone, unless we assume the youngest coin to have penetrated earlier layers, a safer interpretation would therefore be that the deposits labeled Heilige Strasse IV were made after 250 B.C.E., even if some of the finds they contain are older. The so-called Grenzstein (see table 4, no. a13; online appx. 1, table 4, no. a13; fig. 15) mentioned above, a squat limestone cylinder found in the Nordsondage

\footnotetext{
${ }^{131}$ Wintermeyer 2004, 33: "Zum Befund aus den Bodenhorizonten von Straße IV gehören noch kleine Wandungsfragmente von Kantharoi mit Blattzungenriefelung aus der 2. Hälfte des 4 . Jahrhunderts v. Chr." (Some small body fragments of kantharoi with tongue-leaf-shaped ribbing also belong to the soil horizons of Strasse IV). These are sadly not provided with catalogue numbers or depicted in the book, nor do we know to which sublayer of Heilige Strasse IV they belong.
}

and claimed as an archaic horos, ${ }^{132}$ is equally moot in its meaning and date, as it bears no inscription and is unclear in its relationship to the hypothetical road or other structures. Indeed this corner of the sondage was not completely excavated. Beyond the circumstantial fact that it is located next to a later Roman or perhaps Hellenistic road, the basis for calling it an archaic boundary stone remains fragile. ${ }^{133}$ Indeed, the stratigraphy suggests that, by the Late Hellenistic period, this stone was no longer visible.

The earliest plausible road-like surface in the section is Heilige Strasse III, which is made of compressed limestone pebbles (see fig. 15) ${ }^{134}$ and has a probable width of $5.60 \mathrm{~m}$. This feature could well date to the early second century B.C.E. based on the finds from

\footnotetext{
${ }^{132}$ Tuchelt 1984, 222.

${ }^{133}$ Herda 2006, 257 n. 1827.

${ }^{134}$ Identified as horizons N (Nordsondage) 11 and S (Südsondage) 7 (Tuchelt 1984, 221).
} 
above and below this surface, which would make sense in the context of Hellenistic renewal suggested by the building inscriptions reviewed above. On the basis of these small soundings, it is difficult to point to any concrete evidence for a road at this exact location before the Late Classical or Hellenistic era; we can only confirm Archaic-era occupation around the temple at Didyma and presume that there were also paths or roads that served that community. ${ }^{135}$

More recent work near the Temple of Apollo has been similarly inconclusive. Excavations undertaken by successive teams at Didyma in 2008, 2009, and 2013-2015 have aimed to investigate the transition between the paved street excavated by Tuchelt and the temple area to the east. ${ }^{136}$ No continuation of the paved street was found beyond a shelf of bedrock lying close to the modern road (as seen in the trench marked s14 on fig. 12; see also table 3, no. s14; online appx. 1, table 3, no. s14). Trenches dug to the southeast of this bedrock shelf under the modern road (see fig. 12; table 3 , nos. s15, s16; online appx. 1, table 3, nos. s15, s16) found instead approximately $2.5 \mathrm{~m}$ of mixed deposits including sherds from the Archaic to the Byzantine era, ${ }^{137}$ suggesting a considerable degree of post-Roman disturbance including a discarded statue base (see table 3, no. s11; online appx. 1, table 3, no. s11; fig. 16). ${ }^{138}$ How this area between the end of the paved street and the temple looked at any point before this undated disturbance (e.g., whether the road continued or whether this was a relatively open area), or how pilgrims and processions might have continued into the sanctuary, is therefore a matter of speculation. ${ }^{139}$

These excavations reemphasize our relative ignorance of the size and shape of the sanctuary's temenos, and of the extent and date of remodeling phases

\footnotetext{
135 Tuchelt and Schneider's confidence that the Hellenistic and/or Trajanic street was preceded in the Archaic period by a sacred way following more or less the same route perhaps stemmed from the then interpretation of the structures to the southwest of the road as a sanctuary of Artemis. The idea of a sacred way passing directly by such a sacred space seemed entirely natural. Today, when this interpretation has been strongly challenged (Bumke 2006), our understanding of this whole area in the Archaic era remains open.

${ }^{136}$ Furtwängler 2009, 7-9; 2010, 149-51; Slawisch 2013, 57-8; Bumke et al. 2015b, 472, fig. 7 (Area B); 2016, 397, fig. 8 (Area C).

${ }^{137}$ Bumke et al. 2015b, 472, fig. 7.

${ }^{138}$ Furtwängler 2009, 7-9; Slawisch 2013, 57-8.

${ }^{139}$ E.g., Herda 2006, 371-85, fig. 22.
}

(including during the Byzantine and subsequent eras). There is also as yet little evidence for the existence or not of other pathways and roadways in and out of the sacred zone or for how they might have changed in importance through time.

\section{EPISODES OF REINVENTION, REBUILDING, OR REROUTING?}

The epigraphic sources referencing the Sacred Way cluster chronologically around two apparent episodes of renewal, restoration, or, perhaps, (re)invention. The first episode, apparently dating to the late third or early second century B.C.E., is represented by the building inscription (i3) together with the Molpoi inscription (i1). This episode seems to be associated with the final recovery of Miletos and the total reconstruction of the Temple of Apollo in the context of the general Hellenistic prosperity of Asia Minor following the slow recovery of Miletos and Didyma after their destruction in the early fifth century B.C.E. ${ }^{140}$ The Molpoi inscription gives the impression of an attempt to draw heavily on a received or perceived past to justify a renewed cultic energy on the peninsula. As recent literature on the use of the past in the past has emphasized, ${ }^{141}$ it is difficult to gauge the historicity of the traditions behind such projects of renewal, but we should assume a considerable amount of strategically selective memory in the attempt to promote contemporary political interests.

The building inscription from Didyma (see table 1, no. i3; online appx. 1 , table 1 , no. i3) is rather different in character from the Molpoi statutes as a historical source. While some degree of prestige was established or performed through the act of inscribing a text on stone (an expensive undertaking in itself), the political or cultic overtones of the building inscription are relatively mute and instead civic transparency is emphasized. Indeed, the mention of road works is only one item among a whole series of other maintenance costs apparently managed by the temple administration. Nonetheless, taken together, the building inscription, the Molpoi inscription, and the gravestone seem to reflect related processes taking place in different parts of the peninsula. Dating within a few decades of one another, these inscriptions might be taken to signal conscious efforts to create an explicit link between

\footnotetext{
${ }^{140}$ Ehrhardt 2003.

${ }^{141}$ See, e.g., Bradley and Williams 1998.
} 


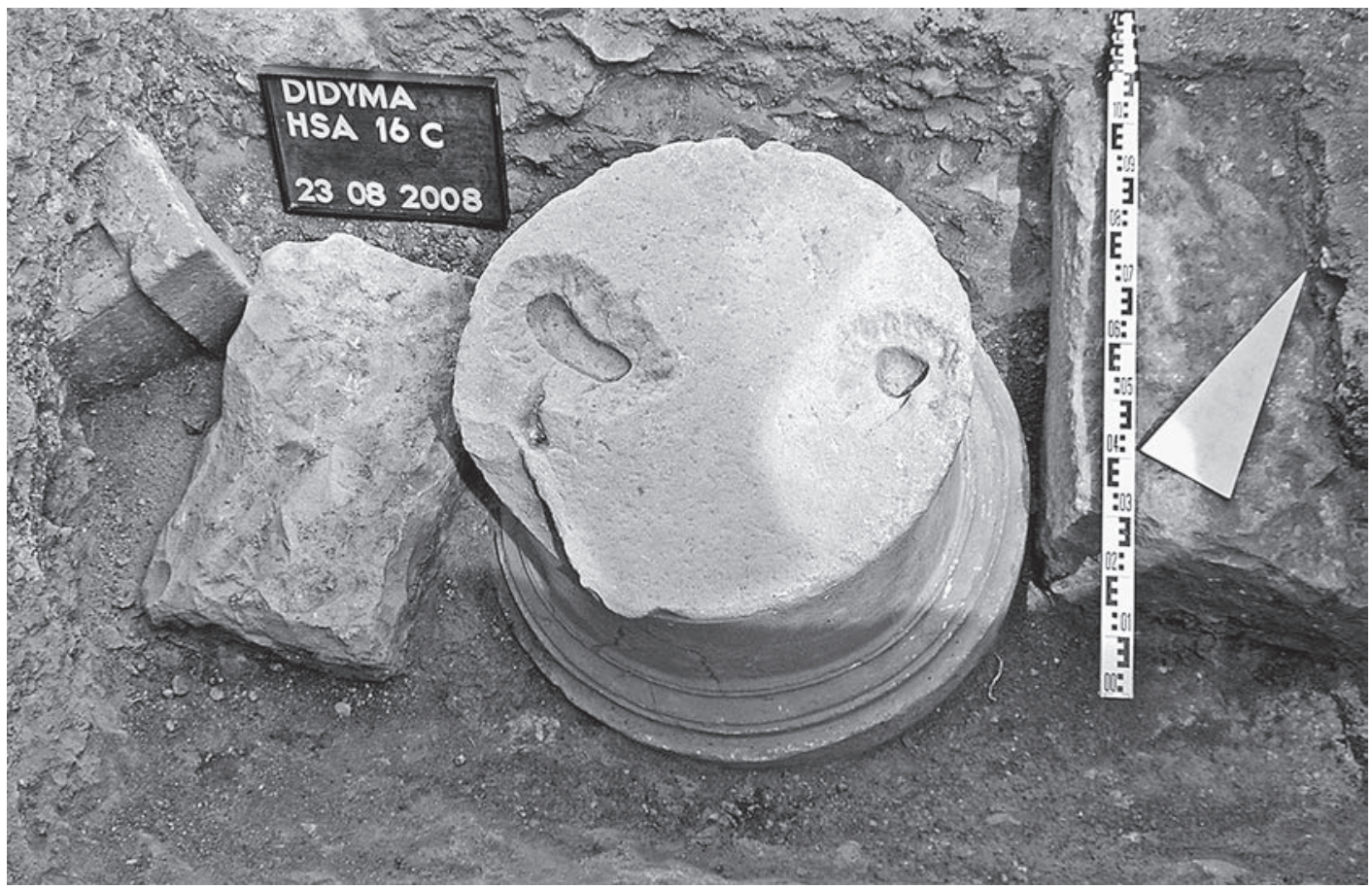

FIG. 16. Statue base (ex situ) in a 2008 sondage at Didyma between the paved section of the Sacred Way and the temple. The sondage produced approximately $2 \mathrm{~m}$ of mixed deposits, including statue bases, but no evidence of a road (A. Slawisch; (C) Didymaarchiv, DAI).

Miletos and Didyma as well as an attempt to maintain or reconstruct an associated set of physical roadways. Perhaps the political project embodied by the publication and display of the Molpoi statutes at the Sanctuary of Apollo Delphinios resulted in an increased use of the road across the Akron to Didyma, hence prompting more systematic maintenance by the authorities. Nonetheless, direct references to the term "Sacred Way" in the second century B.C.E. are geographically restricted, as far as we can tell from such scant remains, and can securely refer only to roads near Didyma.

The second episode, documented by the Trajanic inscriptions (i4-10), dates at least 300 years later. While the project of reconstruction makes use of an existing local tradition, the textual references are much more explicitly oriented around imperial sponsorship. Indeed, there are no direct appeals to the past; the inscription is written as though Trajan had "made" the road himself and highlights the scale of the building work without specifying the actual expenditure (in contrast to the open accountancy of the Hellenistic building inscription). ${ }^{142}$ While contemporary local readers of

\footnotetext{
${ }^{142}$ It is possible that without other information suggesting an
}

the inscription would have been aware of the longer history of processions between Miletos and Didyma, the intended audience of the texts may have been visitors to the city. The references to cutting hills and filling valleys do suggest that the modifications undertaken in Trajan's name might well have been major feats of engineering, which would not be surprising given the scale of works undertaken or sponsored by Trajan in other parts of the empire, ${ }^{143}$ albeit later in his reign. In addition, Trajan's inscriptions are the first that explicitly link the term "Sacred Way" with the entire route between Didyma and Miletos. In this sense, Trajan (or at least Trajan's local agents) may indeed have "made" the Sacred Way in the form in which we now tend to think of it.

Such episodes of renewal and rebuilding should be visible in physical terms through the archaeological remains. As the review above demonstrates, however, solid details about the physical construction, dating,

earlier tradition we would have been tempted to take the textual claim of Trajan having "made" the Sacred Way at face value.

${ }^{143}$ E.g., road works at Terracina, harbor construction at Portus, and lake draining at Fucino (Ehrhardt and Weiß 2011, 247, esp. n. 66; Mitchell 2014). 
and course of the road are elusive. Summarizing the epigraphic and archaeological chronological data (fig. 17) reveals the complexity of the evidence. The segments of paving and curbstones at Didyma (see table 4, no. a14; online appx. 1, table 4, no. a14) and, to a lesser extent, behind the Younger Sacred Gate at Miletos (see table 4, no. a1; online appx. 1, table 4, no. a1) are the clearest evidence for a single episode of construction and have been plausibly identified with Trajan's rebuilding project. Excavations near the paved section at Didyma (see table 3, nos. s4, s6; online appx. 1 , table 3, nos. s4, s6) and in front of the Older Sacred Gate at Miletos (see table 3, no. s1; online appx. 1, table 3, no. s1) revealed possible gravel or compacted surfaces that might date to an episode of Hellenistic maintenance works, although the road surfaces in both places are less clear.

The alignment of archaic complexes of an apparently religious nature along the pass over and valley down from the Akron certainly points to the use of this corridor in the Archaic period. But there is currently no clear evidence for a constructed roadway or constructed road surfaces dating to the Archaic era, either along the Akron track or at any point near Didyma or the Sacred Gate at Miletos. Dating the first or regular use of a rock surface as a road is impossible, though early use is clearly possible. Given the limited nature of the published documentation from sections across the built Stützmauern or curbstones in the Akron Hills along Wilski's Antike Strasse, it is not impossible that parts of these curbs were first set up in the Archaic period. But it is more tempting to link these built elaborations to the track with either a Hellenistic reinvention of an old archaic route or else a Trajanic monumentalization of a traditional road, especially since the epigraphic references to both episodes hint at terracing and since there is possible reuse of archaic masonry next to the Archaic Cult Complex.

This paucity of solid archaeological evidence for an Archaic-era predecessor to the Sacred Way raises questions about the history of the Sacred Way as a whole. Were the early tracks or this intermediate section simply more ephemeral? Was the Sacred Way, as we have come to think about it, actually an invention (and construction) of the Late Classical or Early Hellenistic period? Did the Archaic-era track take a partially or totally different route than was used in later periods? We cannot be sure that the archaic occupants of the Milesian peninsula even had a concept approximating the Sacred Way given the lack of contemporary textual references, and the Molpoi inscription refers only to a "wide road." Our earliest literary reference to a sacred way in the Greek world is Herodotus' fifth-century discussion of the connection between Athens and Delphi. ${ }^{144}$ This may suggest that the idea generally was a fifth-century (and perhaps even specifically Athenian) invention or neologism; in Miletos, the concept might have been adopted to describe the preexisting road even later, perhaps only in the third century B.C.E.

The huge gap in our knowledge about the route in areas such as Akköy and Panormos for the otherwise archaeologically highly visible Trajanic road is also troubling. There is little evidence of landscaping on the scale implied by the inscription from the Sacred Gate. Is it not more likely that such works would have been undertaken in areas most subject to landscape change-for example, in the transitional valleys between Miletos and Akron and between Akron and Didyma (esp. in the harbor area around Panormos) and not along the more restricted course offered by the highland pass and associated valley along a stable bedrock track?

In the following section, we therefore turn in more detail to the geomorphological situation around Panormos and its possible role in the history of the Sacred Way in order to consider possible alternative histories for the road.

\section{LANDSCAPE TRANSFORMATION: GEOMORPHOLOGY AND ROUTE DYNAMISM}

Besides the scale of works claimed, a conspicuous part of Trajan's Sacred Gate inscription is the reference to the necessity of the road. Aside from imperial aggrandizement, complementary mundane, practical considerations may have been involved in the building works. Among them is the relatively unknown extent of landscape change across wider Milesia by the first and second centuries C.E. This change was the result of alluvial deposition from rivers and streams, changing agricultural practices, settlement patterns leading to oscillating levels of colluvial erosion and deposition, ${ }^{145}$ and perhaps in some instances tectonic activity. ${ }^{146}$ If

\footnotetext{
${ }^{144}$ Hdt. 6.34.2.

${ }^{145}$ Brückner 1996; Müllenhoff 2005; Brückner et al. 2006.

${ }^{146}$ E.g., geological investigations show that the modern island of Tavşan Adası, just off the coast on the northern stretch of the harbor of Panormos, was a peninsula in the Bronze Age and probably became an island because of tectonic sinking (Bertemes and Hornung-Bertemes 2009, 170-71; Höfig 2008,
} 


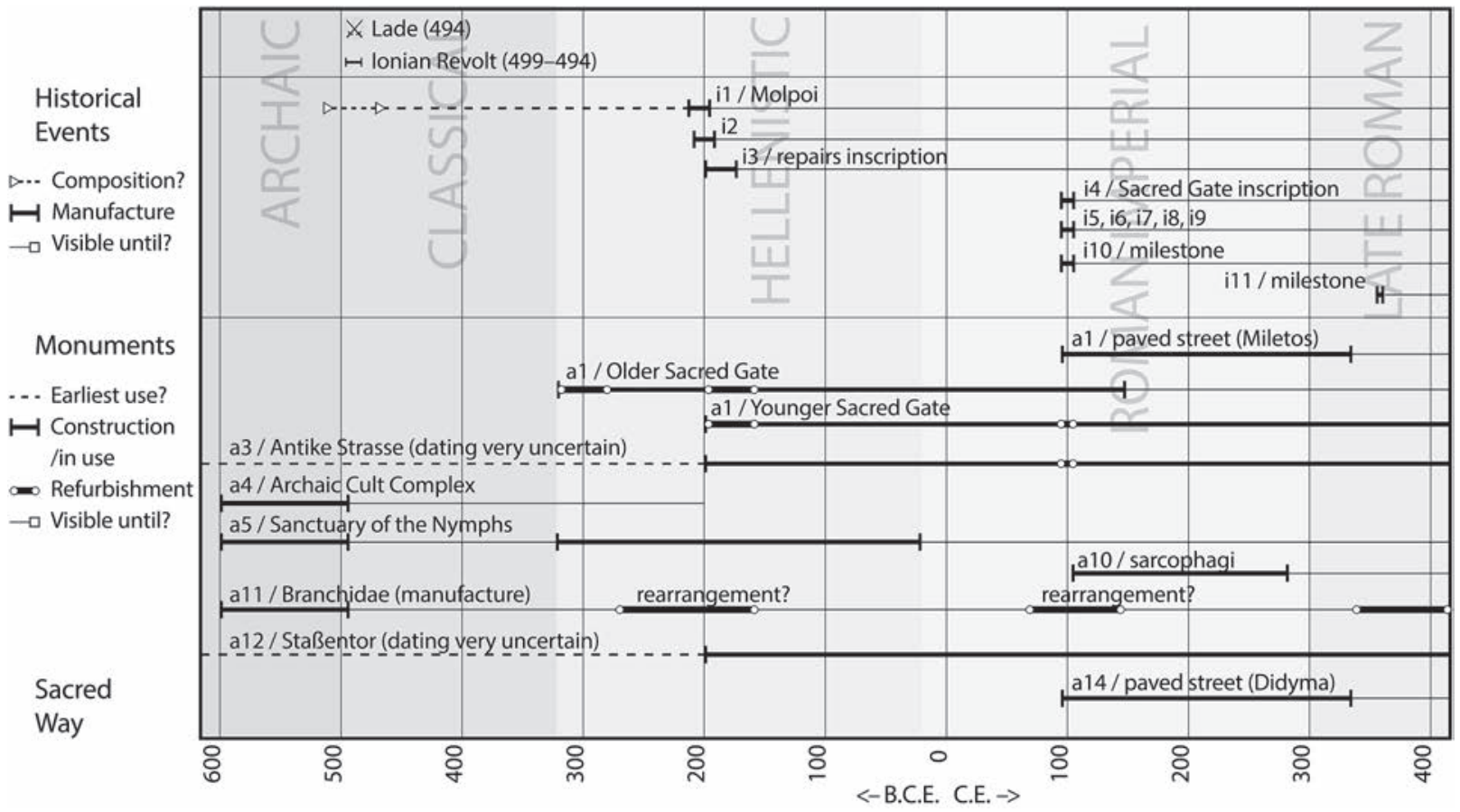

FIG. 17. Diagram summarizing chronological relationship between epigraphic sources and archaeological monuments (drawing by A. Slawisch and T. Wilkinson).

Brückner and his team are broadly correct in their chronological reconstruction of the moving coastline in the Meander Valley, ${ }^{147}$ it seems likely that the city of Miletos was already heavily affected as a seaport by the encroaching delta in the third and fourth centuries C.E. Little historical research has been devoted to the root cause of the fluctuating rate of growth of the delta. Demographics upstream in the Meander catchment must play a part. Higher-intensity tillage or clearance of vegetation upstream would have caused greater quantities of sediment to enter the river during periods of higher population, but little quantitative evidence is available at present to confirm this. On the basis of the pottery density from the small area so far surveyed around $\mathrm{Pa}$ normos, we suspect that the peaks of population in the Milesian peninsula would have been in the Archaic and Roman eras.

On the southwestern side of the peninsula, the area around the harbor of Panormos may have encountered similar albeit much smaller-scale changes in the coastline and topography from the Archaic to the Roman

\footnotetext{
24, 64-75).

${ }^{147}$ Reconstructed coastlines shown in Müllenhoff 2005, fig. 56; Brückner et al. 2006, fig. 2 (with minor modifications).
}

era. The site-oriented extensive surveys by Lohmann aimed at the archaeological remains in the Milesian chora notwithstanding, ${ }^{148}$ we actually know relatively little about the overall biological or geomorphological environment of the peninsula and the extent to which such changes would have affected the human use of the landscape. It is plausible to suggest that part of the motivation for the apparently extensive work carried out in Trajan's name may have been to deal with the consequences of, or to take advantage of, the new topographic and human configuration of the peninsula.

\section{Modeling Routes and Route Dynamism with Friction or Least Cost Analysis}

The application of friction- (or, alternatively, leastcost- or resistance-) based analysis for the purposes of path modeling has a long history in spatial and GISoriented archaeology. ${ }^{149} \mathrm{~A}$ geographic grid of a region is created containing values that represent the relative difficulty (i.e., friction) of traversing each cell of terrain.

\footnotetext{
${ }^{148}$ For interim results from this survey, see Lohmann 1995 , 1997, 1999.

${ }^{149}$ For a general introduction to least cost techniques in archaeology, see Conolly and Lake 2006, 214-25, 253-56.
} 
The grid model can be created in any number of ways, using a variety of factors contributing to friction and different levels of complexity (e.g., whether one takes directionality into account or whether one assumes a degree of symmetry). In practice, topography (or, more precisely, slope) is usually considered the most significant factor contributing to travel friction across terrestrial surfaces, while the means of transportation is a second and less well understood factor. (An explanation of the methods used for the friction analysis presented below are provided in online appx. 2.)

Using the constructed friction model and a set of known origin and destination points, GIS algorithms can identify a "least cost path" representing the easiest or cheapest way to cross the modeled region. ${ }^{150}$ It is important to emphasize the heuristic nature of such models when applied to archaeology. Least cost path analyses can be highly sensitive to small differences in the underlying model, and the actual path created may vary widely depending on the particular algorithm used. The results should certainly not be used to suggest the location of real pathways, which do not always follow rational or economically sensible paths. A "cost corridor" diagram in contrast, while still heuristic in nature, represents a more nuanced map of the probability that paths will be formed along certain corridors in the landscape.

For example, the map shown in figure 18 shows a cost corridor based on a model that uses modern topography as the basis for a friction model. ${ }^{151}$ The start and end points are the Sacred Gate at Miletos and the altar in front of the Temple of Apollo at Didyma, respectively. The cost corridor shows that the most probable (i.e., rationally least costly) route between these two points follows a trajectory along the coast west of the Akron Hills, just as the modern main road does and perhaps as Wiegand imagined the route of Sacred Way would have done. The pass over the Akron along Wilski’s Antike Strasse (marked here by black dashed

\footnotetext{
${ }^{150}$ Algorithms such as Least Cost Path in ESRI's ArcGIS, r.walk in GRASS, and gdistance in R. In general, the use of opensource algorithms rather than proprietary ones is preferable since they provide transparency and future reproducibility of analyses.

${ }^{151}$ Full technical details of the algorithms and procedures used to create the models and maps presented here are available in online appx. 2; updated versions of the scripts and this appendix will be made available at www.projectpanormos.com/ sacredway/.
}

line) falls outside this least cost corridor and therefore provides quantitative support to Herda's argument that the route through the Akron Hills was not designed to follow the most economical route between Miletos and Didyma ${ }^{152}$ but instead was dictated by other motivations (e.g., access to locations of cultural significance, issues of land rights, or, indeed, security).

Both least cost path analyses and cost corridor diagrams form useful tools with which to think about specific questions of mobility and travel, such as the motivations that might have generated real paths. Commonly they are used as a way to construct general or achronological routes for any period. However, they can also be used to compare the potential for travel across different periods if one creates alternative models (hypothetical or evidence-based) for a changing landscape. In this way, surface friction analyses allow us to interrogate the assumption of route inertia and consider whether routes may have varied because of landscape transformation.

\section{The Effects of Landscape Change on Routing the Sacred Way near Panormos}

The likelihood of substantial coastline changes in the flat land around Panormos has been discussed above. While we cannot use friction analyses reliably to predict where we might locate the Sacred Way in the unknown segments, we can use them to gain an impression of the relative probability that roads might have been routed along certain lines at certain times, on the basis of our assessment of the likely changes that have taken place here. The two maps shown in figure 19 represent two alternative probabilities (i.e., two different cost corridor diagrams); the top map in figure 19 is based on the modern coastline at Panormos, and the bottom map is based on a hypothesized alternative coastline lying much farther east in the valleys of Sulubatak and Çınarlı. ${ }^{153}$ Both focus on the uncertain section around Panormos between the terminus of the Antike Strasse (i.e., where the road leaves the Akron Hills) and the altar at Didyma. For the purposes of chronological comparison, the first of these may be

\footnotetext{
${ }^{152}$ Herda 2006, 261.

${ }^{153}$ The exact outline of this area was, for the moment, decided on the basis of modern contours and a visual assessment of the area in the field. Geomorphological work could thus considerably improve our topographic models.
} 


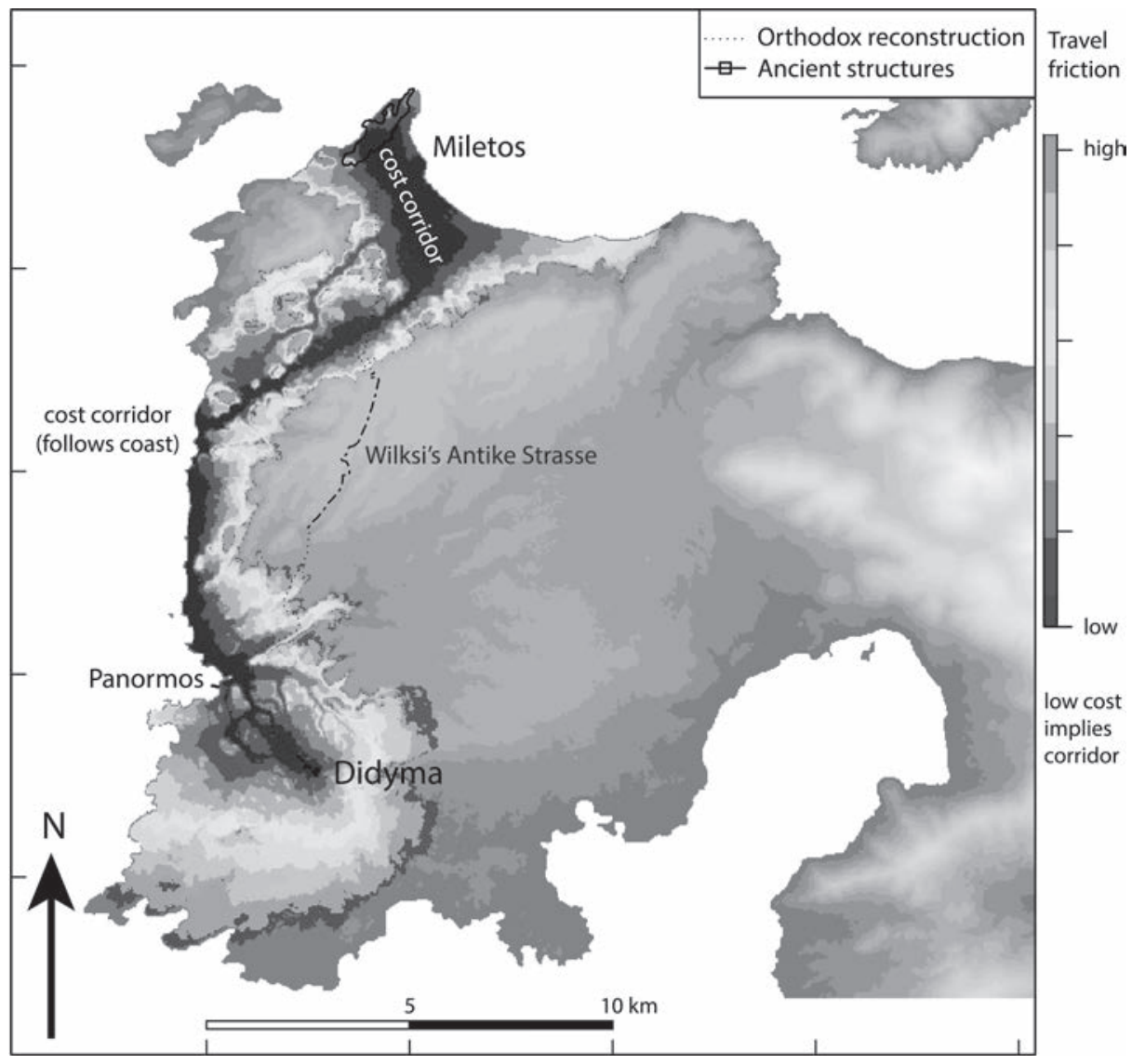

FIG. 18. Cost corridor for entire route between Miletos' Sacred Gate and the altar at Didyma, assuming modern topography and coastline. Wilski's route through the Akron is shown as a dashed line; see also online appendix 2 (drawing by T. Wilkinson and A. Slawisch).

used to approximate the hypothesized situation in the Roman era, and the second may approximate the hypothesized landscape in the Archaic.

With a terrain model that uses the modern coastline (see fig. 19, top), the primary corridor mirrors Schneider's 1987 reconstruction reasonably closely. By contrast, the alternative coastline (see fig. 19, bottom) transforms the probability of transit dramatically, with a primary cost corridor lying some kilometers inland, hypothetically delivering pedestrians from Akron to the opposite (east) side of the sanctuary at Didyma and directly to the altar area in front of the Temple of Apollo, instead of to the northwest side of the temple, as does the route from Panormos. Additionally, the probability is more widely distributed, so there are more secondary or alternative corridors, one of which lies close to Panormos but along a different valley (an eastern extension of the Sulubatak Valley; on Wilski's map, Tu Kodscha to Bogasi). One of these corridors was already discussed as a possible alternative in an unpublished thesis by geologist Katrin Kärner. ${ }^{154}$

\section{An Alternative Route for the Archaic Connection to Didyma?}

The specific route corridors presented in figure 19 (bottom) as potential alternatives are of course highly speculative at present. Nonetheless, there are some indications that encourage us to maintain an open mind about the plausibility of alternative inland routes.

The lack of excavations on the northeastern side of the Temple of Apollo means that we cannot exclude the existence of roads in this area. If we were to assume that this inland route indeed functioned as part of the Molpoi procession from Miletos to Didyma, one of the later stations near Didyma, Keraiites (the "horned"),

\footnotetext{
${ }^{154}$ Kärner 1998, 47-8, appx. E.
} 

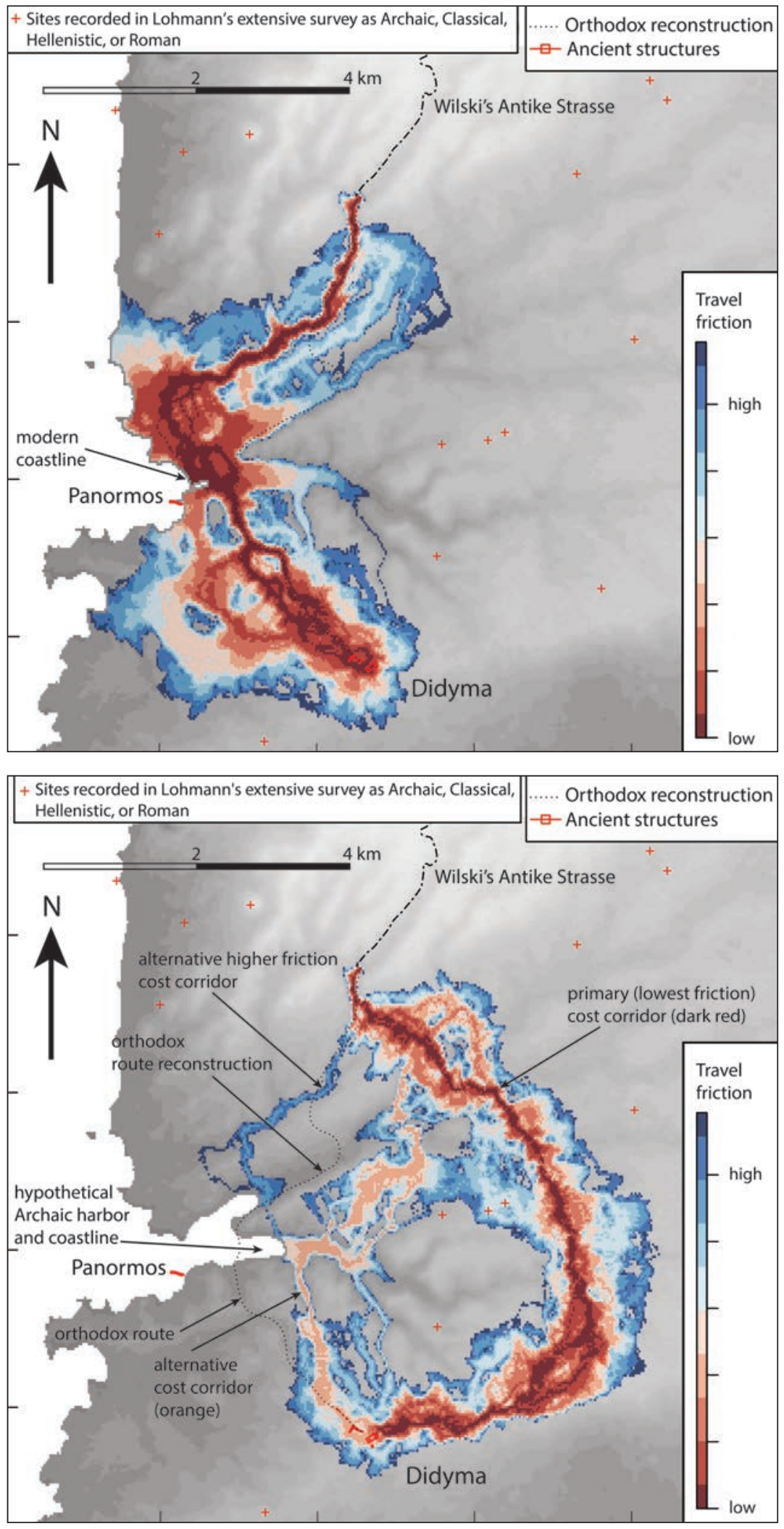

FIG. 19. Cost corridors for the route of the Sacred Way from the south end of Wilski's Antike Strasse to Didyma: top, the model uses topography similar to present day with silted up harbor of Panormos; bottom, the model uses hypothetical topography with unsilted harbor area at Panormos as it might have been in the Archaic era; see also online appendix 2 (drawings by T. Wilkinson and A. Slawisch). 
could also more plausibly refer to the steeper peaks in this part of the peninsula rather than the undulating gradients seen at the coast. Panormos itself is not mentioned in the list of stations in the Molpoi inscription.

While the inland area is relatively empty as far as modern settlement goes, the extensive surveys of the Milesian peninsula by Lohmann and his team confirm the presence of several archaeological sites in this area (marked as red crosses in fig. 19). Among these sites are a possible Hellenistic hamlet and a few graves, probably Hellenistic, ${ }^{155}$ often associated with roadways, as is the case outside the Sacred Gate and near Branchidae at Didyma. ${ }^{156}$ Aerial imagery of the region reveals that this currently unexploited zone of thinsoiled maquis is also covered by various linear features that resemble field clearances or boundaries (fig. 20 also shows the center of the alternative cost corridor as a least cost path). Similar features are also known in the unexploited part of the peninsula southwest of Didyma. Such features are by nature rather difficult to date and interpret. Some may relate to a small Ottoman hamlet (recorded as Turkjeronda on Wilski's map and today known as Islamyoran). ${ }^{157}$

Alternatively, as Borg and Borg have argued, many of the linear features may represent the discarded chippings from the working of stone at the edges of numerous shallow open-cut quarries. ${ }^{158}$ Though the Hellenistic temple at Didyma is clad in marble from the Latmos (according to its chemical signature), the bulk of the volume of the building is filled by limestone similar to those blocks used in the Trajanic paving. This limestone seems to have been sourced locally from the Milesian Peninsula itself. As Borg and Borg argue, the scale of the quarrying activity could have had a "devastating" effect on those areas from which the stone was extracted. The soils of much of this area were of marginal use for crop agriculture in the first

\footnotetext{
${ }^{155}$ Graves include: S401, S402, S408 (Hellenistic?); and a possible Hellenistic hamlet and associated remains S250, S252, S254. Other sites in the area date to the Byzantine or Late Roman periods. See Lohmann (1999) for the interim catalogue.

${ }^{156} \mathrm{On}$ the oft-noted association between graves and roadways, see comments and references in Mohr 2013, 85; Forbeck 1998, esp. 149-91.

${ }^{157}$ Turkjeronda/Türkyoran/Islamyoran is the sister Muslim village to the Orthodox Christian/Greek, or Rum, settlement at Jeronda/Yoran (today's Hisar mahallesi, or district, of the larger Didim ilçe, or municipality), built over the remains of ancient Didyma.

${ }^{158}$ Borg and Borg 2003.
}

place, ${ }^{159}$ and the area might have been slowly abandoned for productive use as its role as a source of stone grew, perhaps especially from the Late Classical era onward in step with the growth of the sanctuary and city.

Environmental and Sociohistorical Motivations Behind Rerouting the Sacred Way

A process of environmental degradation in the inland zone could have many effects on the structure of the landscape and more specifically on the route of any roads across the region. First, an area that might have been sparsely occupied before its exploitation for stone could have become essentially uninhabitable or at least very unattractive. The original environment might not have been too dissimilar from that surrounding Wilski's Antike Strasse. At the edge of this zone, where the limestone overlies marl deposits, are many water sources that could have facilitated a road and cult stations along it. When the environment began to degrade, any road and cult stations might have decreased in appeal. Second, the quarrying and clearance of vegetation might also have encouraged an increasing rate of surface runoff and hence faster alluviation in the valleys to the west around Panormos. Such alluviation in turn might have silted up the inlets of the sea at Panormos and, by enabling transit across an area that had previously been sea, might have opened the possibility for rerouting traffic from Miletos to Didyma via Panormos.

There might also have been social or historical reasons for the abandonment of an inland connection. Mohr recently underlined the role of the creation of processional ways in building community within emerging poleis. ${ }^{160} \mathrm{He}$ argues that the construction of the Sacred Way was a political gesture to encourage peaceful coexistence within newly founded citizen communities of the late seventh and early sixth centuries B.C.E. From this perspective we could see the Sacred Way as a symbolic and isolated path designed to connect preexisting sanctuaries sited in areas with

\footnotetext{
${ }^{159}$ Water retention is very low in these areas of limestone, such that without modern irrigation even olives could have been realistically farmed here only if spaced sufficiently (Borg and Borg 2003, 427).

${ }^{160}$ Mohr 2013, esp. 75, 81-2, 85-6. On the Miletos to Didyma Sacred Way, see Mohr 2013, 87-9. Miletos is referred to as a polis by the late sixth century B.C.E., but the process of its formation is little known (Rubinstein 2004, 1082, no. 854).
} 


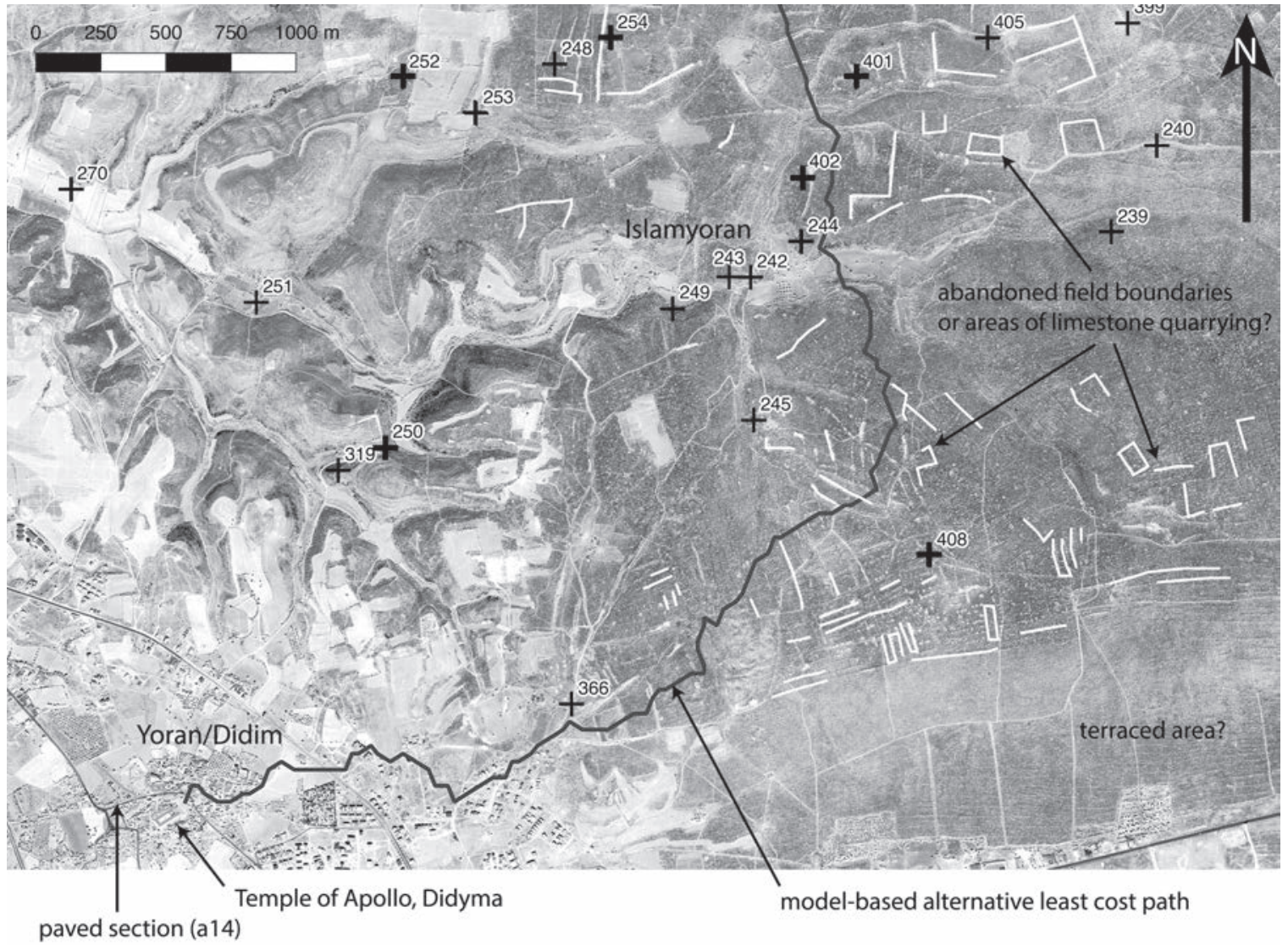

FIG. 20. Worldview-2 satellite image (taken 4 Sep 2011) of area to the northeast of Didyma, showing the hypothetical least cost path, premodern sites (indicated by red crosses) identified in Lohmann's extensive surveys, and linear stone features (clearances, quarry debris) around Islamyoran (base image (C) DigitalGlobe). Site numbers correspond with the catalogue in Lohmann 1999.

marginal agricultural production (and hence less likely to infringe on preexisting competitive land rights).

Mohr's explanation for the impetus behind the creation of the Sacred Way is an attractive model. However, in the absence of references to a sacred way in the inscriptions dating before the third century B.C.E. and of physical remains of any built road dating to the Archaic period, perhaps the ideological and physical "invention" (to follow Hobsbawm's term) of the Sacred Way might better be dated to the Late Classical/ Hellenistic era during the economic and cultural recovery of the Milesian Peninsula. While paths or roads necessarily must have existed to provide access to the cult complexes in the Akron during the sixth century B.C.E., it is less certain that such roads were considered in any sense "sacred" or unified as a single entity known as the "Sacred Way." The preservation of the Akron cult complexes and the ease with which they have been recognized are aspects of their relative remoteness and the marginal productive potential of their locations. We do not know how many other such complexes were distributed across the peninsula since, in those areas closer to later settlement, or in those that experienced quarrying, the robbing of building material was more likely.

Social structures in the Milesian Peninsula were undoubtedly severely affected by the Persian destruction at both Miletos and Didyma after the Ionian revolt, and the revolt itself was triggered by an internal battle for power in Miletos. ${ }^{161}$ If something approximating a sacred way did exist during the Archaic era, it is equally clear that the stations could lose relevance as the priorities and prosperity of the Milesian elites changed. Whatever the date of its composition, the

\footnotetext{
${ }^{161}$ On intrapolis conflict, see Gehrke 1985; Ulf 2011. On internecine origins of the Ionian revolt at Miletos, see Walter 1993; Georges 2000; Kienast 2002.
} 
Molpoi inscription apparently does not mention the archaeologically attested Archaic Cult Complex. This omission could mean that, while the Archaic Cult Complex might have played a part in Archaic-era processions, when the Molpoi text was inscribed in stone in the Early Hellenistic era, more than 300 years after the construction of this complex, the place was no longer in use.

It is possible that by the time Trajan began his " [re-] making" of the Sacred Way another 300 years later, additional older cult centers had become irrelevant, including Molpoi stations that we have not identified in the archaeological record. If new land around Panormos became available because of sedimentation or reclamation (caused perhaps by soil degradation in the inland zone), this would also have been an ideal moment to divert and fractionally shorten this segment of the Sacred Way, literally filling valleys and cutting down hills.

\section{CONCLUDING COMMENTS: ANCIENT AND MODERN CONSTRUCTIONS}

Our analysis in this article has focused on a critical examination of the dating of the epigraphic and archaeological evidence, supplemented by GIS-based modeling of potential routes to understand the impact of possible geomorphological changes. We have argued that, rather than seeing the Sacred Way as a monolithic and unchanging road, we could also use the current evidence to imagine a far more dynamic entity updated physically and reinvented intellectually, in a series of episodes, into something appropriate for the needs of each era. The presence of cult complexes along the Akron road supports the view that a road (or set of tracks) facilitated access to these sites and could have carried cultic processions from at least the sixth century B.C.E. onward. The label "sacred way" may not have been applied to the Akron road until Trajan; it seems more likely to be a Late Classical or Hellenistic coinage that perhaps originally referred only to a section of road near Didyma. The Sacred Way as a unified, specialized road between Miletos and Didyma may only have come into being during the Roman era.

Moreover, we have shown that we cannot exclude the possibility that the physical course of certain segments of the route, particularly around Panormos, might have changed rather dramatically during one of those episodes of reinvention. In the hypothesis we offer here, an older inland pathway of the Archaic (and Hellenistic?) period (see fig. 19, bottom) could have been replaced by a coastal one during the Roman period (see fig. 19, top), perhaps as a result of the obsolescence of inland cultic stations, environmental degradation, and a changing coastline at the harbor at Panormos. This does not mean that the road between Panormos and Didyma was unimportant before then or that an inland route would have been totally abandoned in later times. Many visitors to the oracle sanctuary at Didyma, especially those coming from abroad, might not have arrived via Miletos and walked but instead taken a boat directly to Panormos. It seems likely, too, that many Milesians might have chosen the sea route via Panormos to reach Didyma whenever weather conditions allowed. For heavy or bulk items, sea transport around the peninsula could have been less expensive than taking an overland route, especially one like the Sacred Way that went via the relatively steep gradients of the Akron Hills.

After the reconfiguration of the Sacred Way by Trajan, its importance gradually declined until its rediscovery by European travelers and archaeologists. The 21st-century C.E. response to the Sacred Way appears, strikingly (though perhaps unsurprisingly), as simply another episode of reinvention, akin to the Hellenistic or Trajanic episodes of revival. The process includes an intellectual rediscovery of an ancient practice, physical repairs to the road, the organization of ritual processions (in this case as touristic or cultural hikes), and a program of publicity through the creation of signage along the way (with concrete columned milestones, themselves anachronistic and compressed archaisms; fig. 21), equivalents of which can be seen in the Hellenistic and Trajanic episodes as well. Today the primary agent or owner of this project is the Republic of Turkey, but a secondary and authenticating role is played by local and foreign researchers and the institutes they represent. It might not be surprising if, at some point, a program of intensive building were proposed to allow the Sacred Way to make its new role as a processional route for tourists (the modern equivalent of pilgrims) more convenient. The modern restoration of ancient monuments tends to aim for historical authenticity, of a fixing of identity based on the past, but it inevitably results in a creation that appeals to contemporary political, social, and economic priorities in a form that has never existed before. ${ }^{162}$

\footnotetext{
${ }^{162}$ On the politics of reconstruction or restoration of ancient monuments, see, e.g., Yalouri 2001; Jusdanis 2004.
} 


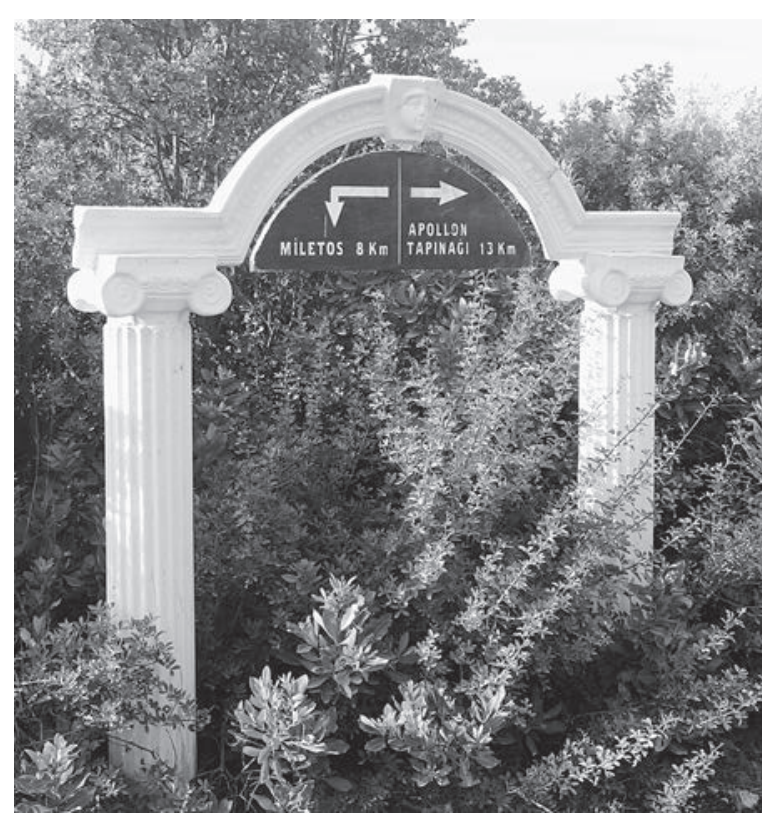

FIG. 21. One of several modern signposts with distances along the Kutsal Yol hiking trail, this one sited near the highest point of the Akron, 2016 (T. Wilkinson; (C) Project Panormos).

Each of the episodes of reconstruction on the Sacred Way that we have discussed above represents a defining of its character based on past traditions and current concerns. Perhaps, in proposing possible past changes in the route, we can counter the automatic assumption of route inertia that so frequently underlies the discussion of ancient roads. Finally, in catalyzing discussion on the diachronic role of this road, we hope to encourage reflection on the parallels between the ancient and modern construction projects, especially the dynamics of authority and authenticity, and ultimately to encourage a long and more plural future both for the idea of the Sacred Way and for the physical remains along its probable route(s).

Anja Slawisch

Faculty of Classics

University of Cambridge

Sidgwick Avenue

Cambridge CB3 9DA

United Kingdom

as2563@cam.ac.uk

Toby C. Wilkinson

Churchill College

Cambridge CB3 0DS

United Kingdom

tcw50@cam.ac.uk
Works Cited

Agelidis, S. 2012. "Zur architektonischen Fassung von Prozessionswegen." In Manifestationen von Macht und Hierarchien in Stadtraum und Landschaft, edited by F. Pirson, 81-98. Byzas 13. Istanbul: Deutsches Archäologisches Institut.

Appadurai, A. 1981. “The Past as a Scarce Resource." Man 1(2):201-19.

Bekker-Nielsen, T. 2009. "Strassen, Heiligtümer und heilige Strassen.” In Die Landschaft und die Religion, Stuttgarter Kolloquium zur Historischen Geographie des Altertums 9, 2005, edited by E. Olshausen and V. Sauer, 9-15. Geographica Historica 26. Stuttgart: Franz Steiner.

Bertemes, F., and K. Hornung-Bertemes. 2009. "Minoer in Didyma: Ein Siegel und seine Geschichte.” In Zurück zum Gegenstand: Festschrift für Andreas E. Furtwängler, edited by R. Einicke et al., 169-94. Langenweißbach, Germany: Beier and Beran.

Borg, G., and B.E. Borg. 2003. "From Small Quarries to Large Temples-The Enigmatic Source of Limestone for the Apollo Temple at Didyma, W-Anatolia." In ASMOSIA VI: Interdisciplinary Studies on Ancient Stone. Proceedings of the Sixth International Conference of the "Association for the Study of Marble and Other Stones in Antiquity," Venice, June 15-18 2000, edited by L. Lazzarini, 427-36. Padua: Bottega d'Erasmo Aldo Ausilio Editore.

Boutsikas E., and C. Ruggles. 2011. "Temples, Stars, and Ritual Landscapes: The Potential for Archaeoastronomy in Ancient Greece." AJA 115(1):55-68.

Bradley, R., and H. Williams, eds. 1998. "The Past in the Past: The Reuse of Ancient Monuments." Special issue, WorldArch 30(1).

Brückner, H. 1996. "Geoarchäologie an der türkischen Ägäisküste: Landschaftswandel im Spiegel geologischer und archäologischer Zeugnisse." Geographische Rundschau 10:568-74.

Brückner, H., M. Müllenhoff, R. Gehrels, A. Herda, M. Knipping, and A. Vött. 2006. "From Archipelago to Floodplain-Geographical and Ecological Changes in Miletus and Its Environs During the Past Six Millennia (Western Anatolia, Turkey)." Supplement, Zeitschrift für Geomorphologie N.F. 142:63-83.

Brückner, H., A. Herda, M. Kerscher, M. Müllenhoff, and F. Stock. 2017. "Life Cycle of Estuarine Islands-From the Formation to the Landlocking of Former Islands in the Environs of Miletos and Ephesos in Western Asia Minor (Turkey).” JAS: Reports 12:876-94.

Bumke, H. 2006. "Die Schwester des Orakelgottes: Zum Artemiskult in Didyma." In Archäologie und Ritual: Auf der Suche nach der rituellen Handlung in den antiken Kulturen Ägyptens und Griechenlands, edited by J. Mylonopoulos and H. Roeder, 215-37. Vienna: Phoibos.

Bumke, H., A. Herda, E. Röver, and T.G. Schattner. 2000. "Bericht über die Ausgrabungen 1994 an der Heiligen Straße von Milet nach Didyma: Das Heiligtum der Nymphen?" AA:57-97.

Bumke, H., J. Breder, I. Kaiser, B. Reichardt, U. Weber, M. Kohnert and G. Pantelidis. 2015a. "Didyma: Bericht über 
die Arbeiten der Jahre 2010-2013.” AA:109-72.

Bumke, H., F. Bertemes, H. Cevizoğlu, and E. von Gaisberg. 2015b. "Didyma 2013." Kazı Sonuçları Toplantısı 36(2): 467-88.

Bumke, H., H. Cevizoğlu, E. von Gaisberg, F. Bertemes, and A. Tanriöver. 2016. "Didyma 2014." Kazı Sonuçları Toplantisı 37(3):391-416.

Chandler, R. 1776. Travels in Greece: Or an Account of a Tour Made at the Expense of the Society of the Dilettanti. Pt. 4. Oxford: Clarendon Press.

Chaniotis, A. 2010. "The Molpoi Inscription: Ritual Prescription or Riddle?” Review of Der Apollon-DelphiniosKult in Milet und die Neujahrsprozession nach Didyma: Ein neuer Kommentar der sog. Molpoi-Satzung, by A. Herda. Kernos 23:375-417.

Clinton, K. 2005. Eleusis: The Inscriptions on Stone. Documents of the Sanctuary of the Two Goddesses and the Public Documents of the Deme. Athens: Archaeological Society at Athens.

Clow, K. 2014. The Lycian Way: Turkey's First Long Distance Walking Route. Istanbul: Upcountry (Turkey) Limited.

Conolly, J., and M.W. Lake. 2006. Geographical Information Systems in Archaeology. Cambridge: Cambridge University Press.

Ehrhardt, N. 1993. "Zwei Archaische Statuen mit NymphenWeihungen aus Milet." EpigAnat 21:3-8.

1998. "Didyma und Milet in archaischer Zeit." Chiron 28:11-20.

. 2003. "Milet nach den Perserkriegen: Ein Neubeginn?" In Stadt und Stadtentwicklung in Kleinasien, edited by E. Schwertheim, 1-19. Asia Minor Studien 50. Bonn: R. Habelt.

Ehrhardt, N., and P. Weiß. 1995. "Trajan, Didyma und Milet: Neue Fragmente von Kaiserbriefen und ihr Kontext." Chiron 25:315-55.

_ 2011. "Eine monumentale Dankesgabe: Trajans Neubau der Heiligen Straße von Milet nach Didyma." Chiron 41:217-62.

Feyel, C. 2006. Les artisans dans les sanctuaires grecs aux époques classique et hellénistique à travers la documentation financière en Grèce. Athens: École Française d'Athènes.

Fontenrose, J. 1988. Didyma: Apollo's Oracle, Cult, and Companions. Berkeley: University of California Press.

Forbeck, E. 1998. "Die Nekropolen von Milet: Die Grabungen 1901 bis 1909 und die Arbeiten der Jahre 1993 bis 1996." Ph.D. diss., Ruhr-Universität Bochum. http://hssopus.ub.ruhr-uni-bochum.de/opus4/frontdoor/index/ index/docId/4915.

French, D. 2014. Roman Roads and Milestones of Asia Minor. Vol.3, Milestones. Fasc. 3, pt. 5, Asia. BIAAElectronic Monograph 5. Ankara: British Institute at Ankara. http://biaa. ac.uk/publications/item/name/electronic-monographs.

Furtwängler, A.E. 2009. "Didyma: Ein Überblick über die jüngeren Forschungen." Colloquium Anatolicum 8:1-17.

_. 2010. "Didyma 2008." Kazı Sonuçları Toplantısı 31(2):145-64

. 2014. "Didyma 494-334 BC: Why Did the Oracle Remain Silent?" In Vom Troglodytenland ins Reich der Scheherazade: Archäologie, Kunst und Religion zwischen Orient und Okzident. Festschrift für Piotr O. Scholzzum 70. Geburtstag, edited by M. Dlugos, 241-48. Berlin: Frank \& Timme.

Gehrke, H.-J. 1985. Stasis: Untersuchungen zu den inneren Kriegen in den griechischen Staaten des 5. und 4. Jahrhunderts v. Chr. Vestigia 35. Munich: Beck.

Gell, W. 1819. The Itinerary of Greece: Containing One Hundred Routes in Attica, Boeotia, Phocis, Locris, and Thessaly. London: John Rodwell.

Georges, P.B. 2000. "Persian Ionia Under Darius: The Revolt Reconsidered.” Historia 49:1-39.

Gödecken, K.B. 1986. "Beoachtungen und Funde an der Heiligen Strasse zwischen Milet und Didyma, 1984." ZPE $66: 217-253$.

Günther, L.-M. 2014. Bürgerinnen und ihre Familien im hellenistischen Milet: Untersuchungen zur Rolle von Frauen und Mädchen in der Polis-Öffentlichkeit. Wiesbaden: Harrassowitz.

Heidegger, M. 1977. “The Age of the World Picture.” In The Question Concerning Technology and Other Essays, 115-54. Translated by W. Lovitt. New York and London: Garland Publishing.

Herda, A. 2006. Der Apollon-Delphinios-Kult in Milet und die Neujahrsprozession nach Didyma: Ein neuer Kommentar der sog. Molpoi-Satzung. Milesische Forschungen 4. Mainz: Philipp von Zabern.

Herrmann, P. 1997. Inschriften von Milet. Pt. 1B, Nachträge und Übersetzungen zu den Inschriften n. 1-406. Berlin: Walter de Gruyter.

Hobsbawm, E. 1992. “Introduction: Inventing Traditions.” In The Invention of Tradition, edited by E. Hobsbawm and T. Ranger, 1-14. Cambridge: Cambridge University Press.

Höfig, T. 2008. "Die Geologie von Tavşan Adası und der angrenzenden Küste unter geoarchäologischen Gesichtspunkten, Ägäis, SW-Türkei." Diplomkartierung (unpublished diploma thesis), Institut für Geowissenschaften der Martin-Luther-Universität Halle-Wittenberg.

Jones, C.P. 1975. "An Oracle Given to Trajan." Chiron 5: 403-6.

Jusdanis, G. 2004. "Farewell to the Classical: Excavations in Modernism." Modernism/Modernity 11(1):37-53.

Kärner, K. 1998. "Geologische Kartierung im Maßstab 1:10.000 der neogenen Sedimente nordöstlich von Mavişehir (Milesische Halbinsel/Südwest Türkei).” Diplomkartierung (unpublished diploma thesis), Institut für Geowissenschaften der Martin-Luther-Universität HalleWittenberg.

Kienast, D. 2002. "Bemerkungen zum Jonischen Aufstand und zur Rolle des Artaphernes.” Historia 51:1-31.

Knackfuß, H. 1941. Didyma. Vol. 1, Die Baubeschreibung: In drei Bänden. Berlin: Gebr. Mann.

Köcke, L.S. 2014. “Neubürgerinnen in Milet.” In Bürgerinnen und ihre Familen im hellenistischen Milet: Untersuchungen zur Rolle von Frauen und Mädchen in der Polis-Öffentlichkeit, edited by L.-M. Günther, 263-302. Wiesbaden: Harrossowitz.

Llobera, M. 2007. "Reconstructing Visual Landscapes.” WorldArch 39(1):51-69.

Lohmann, H. 1995. "Survey in der Chora von Milet: Vorbericht über die Kampagnen der Jahre 1990, 1992 und 1993.” AA:293-328. 
1997. "Survey in der Chora von Milet: Vorbericht über die Kampagnen der Jahre 1994 und 1995.” AA: 285-311.

. 1999. "Survey in der Chora von Milet: Vorbericht über die Kampagnen der Jahre 1996 und 1997." AA: 439-73.

Mitchell, S. 2014. "Trajan and the Cities of the East." In Trajan und seine Städte: Colloquium Cluj-Napoca, 29. September-2. Oktober 2013, edited by I. Piso and R. Varga, 225-32. ClujNapoca, Romania: Mega.

Mohr, M. 2013. Die Heilige Strasse-Ein "Weg der Mitte"? Soziale Gruppenbildung im Spannungsfeld der archaischen Polis. Züricher Archäologische Forschungen 1. Rahden: Marie Leidorf.

Müllenhoff, M. 2005. Geoarchäologische, sedimentologische und morphodynamische Untersuchungen im Mündungsgebiet des Büyük Menderes (Mäander), Westtürkei. Marburg, Germany: Marbuger Geographische Gesellschaft.

Parker, R. 2008. Review of Der Apollon-Delphinios-Kult in Milet und die Neujahrsprozession nach Didyma: Ein neuer Kommentar der sog. Molpoi-Satzung, by A. Herda. CR 58(1):178-80.

Peek, W. 1971. “Griechische Versinschriften." ZPE 7:193-226.

Rehm, A. 1914. “Die Inschriften.” In Das Delphinion in Milet, edited by G. Kawerau and A. Rehm, 162-406. Milet 1(3). Berlin: Georg Reimer.

. 1958. Didyma. Vol. 2, Die Inschriften. Berlin: Gebr. Mann.

Rhodes, P.J. 2006. “Milesian 'Stephanephoroi’: Applying Cavaignac Correctly.” ZPE 157:116.

Ross, L. 1861. "Die Statuen am heiligen Wege der Branchiden.” Archäologische Aufsätze 2:378-83. Originally published in AZ 8 (1850):129-35.

Rubinstein, L. 2004. "Ionia." In An Inventory of Archaic and Classical Poleis: An Investigation Conducted by the Copenhagen Polis Centre for the Danish National Research Foundation, edited by M.H. Hansen and T.H. Nielsen, 1053-107. Oxford: Oxford University Press.

Schneider, P. 1987. "Zur Topographie der Heiligen Straße von Milet nach Didyma." AA:101-29.

Slawisch, A. 2009. "Epigraphy Versus Archaeology: Conflicting Evidence for Cult Continuity in Ionia During the Fifth Century BC." In Sacred Landscapes in Anatolia and Neighboring Regions, edited by C. Gates, J. Morin, and T. Zimmermann, 29-34. BAR-IS 2034. Oxford: Archaeopress.

. 2013. "Didyma: Untersuchungen zur sakralen Topographie und baulichen Entwicklung des Kernheiligtums vom 8.-4.Jh. v. Chr." In Heiligtümer: Gestalt und Ritual, Kontinuität und Veränderung. Sanktuar und Ritual Heilige Plätze im archäologischen Befund, edited by I. Gerlach and D. Raue, 53-60. Forschungscluster 4. Rahden: Marie Leidorf. 2 2014. "e-Projektbericht: Die archaische Nekropole von Panormos, 2012 und 2013." eDAI-F 2014-3:114-119.

Society of Dilettanti. 1821. Antiquities of Ionia. London: Society of Dilettanti.

Sokolowski, F. 1955. Lois sacrées de l'Asie Mineure. Paris: De Boccard.

Texier, C. 1849. Déscription de l'Asie Mineure faite par ordre du Gouvernement Français de 1833 à 1837. Vol. 2. Paris:
Ministère de l'Instruction Publique.

Thomas, J. 1993. "The Politics of Vision and the Archaeologies of Landscape." In Landscape: Politics and Perspectives, edited by B. Bender, 19-48. Oxford: Berg.

Tuchelt, K. 1970. Die Archaischen Skulpturen von Didyma, Beiträge zur frühgriechischen Plastik in Kleinasien. IstForsch 27. Berlin: Mann.

1973. Vorarbeiten zu einer Topographie von Didyma: Eine Untersuchung der inschriftlichen und archäologischen Zeugnisse. IstMitt-BH 9. Tübingen: E. Wasmuth.

. 1980. "Didyma: Bericht über die Arbeiten der Jahre 1975-1979.” IstMitt 30:99-189.

. 1984. "Didyma: Bericht über die Arbeiten der Jahre 1980-1983.” IstMitt 34:193-344.

. 1985-1986. "Didyma-Grabung, Tagebuch 2/5, 1985 II. 1986. I (1144-1338).” Unpublished field notebook. Berlin: DAI, Didymaarchiv.

.1986-1987. "Didyma-Grabung Tagebuch 2/6, 1986 II. 1987 (1339-1534).” Unpublished field notebook. Berlin: DAI, Didymaarchiv.

. 1987. "Bericht über die Arbeiten der DidymaGrabung 1986.” Kazı Sonuçları Toplantısı 9(2):77-81. . 1989. "Bericht über die Arbeiten der DidymaGrabung 1988.” Kazı Sonuçları Toplantısı 11(2):43-52. . 1990. "Didyma-Grabung 1989." Kazı Sonuçları Toplantısı 12(2):95-104.

1991. "Branchidai-Didyma: Geschichte, Ausgrabung und Wiederentdeckung eines antiken Heiligtums-1765 bis 1990." AntW 22.

2000. "Der Vorplatz des Apollontempels von Didyma und Seine Umgebung: Eine Fallstudie zur Rekonstruktion von Befund, Prozess und Gestalt." ÖJh 69:311-56.

Tuchelt, K., P. Schneider, T.G. Schattner, and H.R. Baldus. 1989. "Didyma: Bericht über die Ausgrabungen 1985 und 1986 an der Heiligen Straße von Milet nach Didyma." AA:143-217.

Tuchelt K., P. Schneider, T.G. Schattner, and H.R. Baldus. 1996. Ein Kultbezirk an der Heiligen Straße von Milet nach Didyma. Didyma 3(1). Mainz: Philipp von Zabern.

Ulf, C. 2011. "Zur Vorgeschichte der Polis: Die Wettbewerbskultur als Indikator für die Art des politischen Bewusstseins." Hermes 139(3):291-315.

von Gerkan, A. 1935. Die Stadtmauern. Milet 2(3). Berlin: Walter de Gruyter.

von Wilamowitz-Moellendorff, U. 1904. Satzungen einer milesischen Sängergilde. Sitzungsberichte der Königlich Preussischen Akademie der Wissenschaften 19. Berlin: Verlag der Königlichen Akademie der Wissenschaften. . 1906. "Rezension zu Milet I." GGA 8:635-40.

Walter, U. 1993. "Herodot und die Ursachen des Ionischen Aufstandes.” Historia 42:257-78.

Wiegand, T. 1901. "Ausgrabungen in Milet, Zweiter vorläufiger Bericht über die von den Königlichen Museen begonnenen Ausgrabungen in Milet." SBBerl:903-13.

. 1903-1904. "Grabungstagebuch der Miletgrabung. Mil. 32: Milet III. Herbst 1903 bis 5 Apr 1904.” Unpublished field notebook. Berlin: Berlin Antikenmuseum. . 1911. "Siebenter vorläufiger Bericht über die von den Königlichen Museen in Milet und Didyma unternomm- 
enen Ausgrabungen." SBBerl:1-71.

ed. 1929. Die milesische Landschaft. Milet 2(2). Berlin: Hans Schoetz und Co.

Wilkinson, T.C. 2014. Tying the Threads of Eurasia: Transregional Routes and Material Flows in Transcaucasia, Eastern Anatolia and Western Central Asia, ca. 3000-1500 BC. Leiden: Sidestone Press.

Williamson, C. 2014. "A Room with a View: Karian Landscape on Display Through the Andrones at Labraunda." In Labrys: Studies Presented to Pontus Hellström, edited by
L. Karlsson, S. Carlsson, and J.B. Kullberg, 123-38. Boreas 35. Uppsala: Uppsala University.

Wilski, P. 1906. Karte der Milesischen Halbinsel (1:50000): Mit erläuterndem Text. Milet 1(1). Berlin: Georg Reimer. Wintermeyer, U.2004. Die hellenistische und frühkaiserzeitliche Gebrauchskeramik: Auf Grundlage der stratifizierten Fundkeramik aus dem Bereich der Heiligen Strasse. Didyma 2(3). Mainz: Philipp von Zabern.

Yalouri, E. 2001. The Acropolis: Global Fame, Local Claim. Oxford: Berg. 